PRZEGLĄD NAUK HISTORYCZNYCH 2017, R. XVI, NR 1

http://dx.doi.org/10.18778/1644-857X.16.01.02

ZBigniew ANUSIK

UNIWERSYTET ŁÓDZKI

\title{
Gustaw III wobec rewolucji francuskiej
}

Streszczenie. Gustaw III panował w Szwecji w latach 1771-1792. Od poczatku swoich rządów był mocno związany z Francją. Dzięki jej poparciu dokonał monarchistycznego zamachu stanu w sierpniu 1772 r. Przez kolejnych 15 lat był najbliższym sojusznikiem dworu wersalskiego. Zapoczątkowany w 1787 r. kryzys wewnętrzny sprawił, że Francja nie była w stanie dłużej odgrywać dotychczasowej roli na arenie międzynarodowej. Jednym $z$ pierwszych polityków europejskich, który zdał sobie $z$ tego sprawę, był właśnie Gustaw III. W latach 1788-1790, wbrew stanowisku Francji, prowadził wojnę $z$ Rosja, która zakończył w sierpniu 1790 r. Nie ulega najmniejszej wątpliwości, że zrobił to ze względu na rozwój sytuacji we Francji. Król od dawna panicznie bał się bowiem wszelkich rewolucji. I nie chodziło mu bynajmniej o wywołane przez nie zmiany natury społecznej czy gospodarczej. W rewolucji król szwedzki widział niszczycielską siłę zagrażająca wszystkim tronom. Obawiał się, że przykład Francji, gdzie pozycja króla słabła z każdym miesiącem, może doprowadzić do upadku monarchii we wszystkich innych krajach europejskich. $Z$ tego właśnie powodu Gustaw III powziął myś1 o dokonaniu zbrojnej interwencji we Francji.

W 1791 r. sprawą dla niego najważniejszą było już bowiem ratowanie zagrożonej monarchii francuskiej. Nie znajdując zrozumienia u przedstawicieli państw trójprzymierza (Anglia, Prusy, Holandia), coraz bardziej zaczynał skłaniać się ku koncepcji zawarcia przymierza z Rosja. Decyzję o podpisaniu traktatu sojuszniczego z Katarzyną II przesądziło niepowodzenie ucieczki Ludwika XVI z Paryża w czerwcu 1791 r. Niemal natychmiast po zatrzymaniu króla Francji w Varennes Gustaw III przystapił do montowania szerokiej koalicji mocarstw, której pierwszoplanowym celem miało być ratowanie instytucji francuskiej monarchii. Jego inicjatywy $\mathrm{w}$ tym względzie nie znalazły jednak zrozumienia na dworach europejskich. Dyplomaci szwedzcy niemal wszędzie spotkali się $z$ chłodnym, a niekiedy nawet $z$ wrogim przyjęciem. Jedynym rezultatem zakrojonej na szeroką skalę akcji dyplomatycznej okazało się podpisanie traktatu drottningholmskiego $z$ Rosją w październiku 1791 r. Warto też zwrócić uwage

*Wydział Filozoficzno-Historyczny, Instytut Historii, Katedra Historii Nowożytnej, e-mail: zanusik@uni.lodz.pl. 
na to, że Gustaw III pozostawał w stałym kontakcie $z$ Ludwikiem XVI i jego zaufanym przedstawicielem na emigracji - Louisem Auguste'em baronem de Breteuil. Gustaw III został zamordowany w chwili, kiedy jego propozycje zostały zaakceptowane przez Ludwika XVI i Marię Antoninę. Dwór tuileryjski początkowo dość sceptycznie odnosił się bowiem do pomysłu zbrojnej interwencji we Francji. Jednak w marcu 1792 r. baron de Breteuil, występując w imieniu francuskiej pary królewskiej, zgodził się zarówno na lądowanie szwedzkiego korpusu w Normandii, jak i na zorganizowanie nowej ucieczki rodziny królewskiej z Paryża. Śmierć Gustawa III przekreśliła wszystkie te zamiary. Umierający król nigdy nie miał się też dowiedzieć, że w końcu marca 1792 r. pojawiła się szansa na spełnienie wszystkich jego pragnień i marzeń.

Słowa kluczowe: Gustaw III, rewolucja francuska 1789-1792, Szwecja w II połowie XVIII w., polityka zagraniczna Szwecji w II połowie XVIII w., sytuacja polityczna w Europie w II połowie XVIII w.

7 ustaw III (1746-1792) był jednym $z$ najwybitniejszych władców Szwecji w epoce nowożytnej. Niemal w każdym podręczniku historii wspomina się go jako króla, który dokonując w sierpniu 1772 r. monarchistycznego zamachu stanu, zakończył w dziejach swego kraju charakteryzująca się przewagą stanów nad korona „epokę wolności”. Współcześni historycy widzą też w Gustawie III jednego $z$ najważniejszych przedstawicieli tzw. oświeconego absolutyzmu oraz ostatniego władcę Szwecji, który potrafił skutecznie wojować $z$ imperium rosyjskim. Należy w tym kontekście odnotować to, że niemal do końca XX stulecia historycy polscy nie przejawiali żadnego zainteresowania polityka Gustawa III wobec rewolucyjnej Francji. Problem ten znalazł natomiast odzwierciedlenie w pracach historyków zachodnioeuropejskich, spośród których warto przywołać nazwiska Alberta Geffroya ${ }^{1}$, Nilsa Åkesona ${ }^{2}$, Roberta Nisbeta Baina ${ }^{3}$, Almy Söderhjelm ${ }^{4}$, Beth Hennings ${ }^{5}$ czy wreszcie Claude'a Nordmanna ${ }^{6}$. Również piszacy te słowa opublikował dwie książki poświęcone polityce Szwecji wobec Francji w czasach

${ }^{1}$ Por. A. Geffroy, Gustave III et la cour de France. Suivi d'une etude critique sur Marie-Antoinette et Louis XVI apocryphes, t. I-II, Paris 1867.

2 N. Åkes o n, Gustaf III:s förhållande till franska revolutionen, Bd I-II, Lund $1885-1886$.

${ }^{3}$ R.N. Bain, Gustavus III and his Contemporaries 1746-1792. An Overlooked Chapter of Eighteenth Century History, vol. I-II, London 1894.

${ }^{4}$ A. Söderhjelm, Sverige och den franska revolutionen. Bidrag till kännedom om Sveriges och Frankrikes inbördes förhållande i slutet av 1700-talet, Bd I (Gustav III:s tid), Stockholm 1920.

${ }^{5}$ B. Hennings, Gustav III. En biografi, Stockholm 1957.

${ }^{6}$ Por. C. Nordmann, Gustave III. Un democraté couronné, Lille 1986. 
panowania Gustawa III ${ }^{7}$. W zdecydowanej większości przypadków sa to jednak prace, w których interesujaca nas kwestia traktowana jest w sposób bardzo szeroki, a król nie jest bynajmniej jedynym bohaterem narracji. W literaturze przedmiotu nadal brakuje zatem opracowania, które przedstawiałoby stosunek Gustawa III do rewolucji francuskiej widziany przez pryzmat podejmowanych przez niego działań i wyrażanych przez niego opinii. Tekst ten stanowi próbę wypełnienia tej luki.

Przyszły Gustaw III, najstarszy syn ówczesnego następcy szwedzkiego tronu, Adolfa Fryderyka $z$ dynastii Holstein-Gottorp i Ludwiki Ulryki ks. Pruskiej, przyszedł na świat 24 stycznia/4 lutego 1746 r. w Sztokholmie. Od najmłodszych lat był bardzo mocno związany $z$ matka, która w znacznym stopniu przyczyniła się do ukształtowania jego osobowości. Po Hohenzollernach odziedziczył też większość cech swojego charakteru. Przez całe życie był bowiem niezwykle gwałtowny, impulsywny, porywczy i nerwowy. Miał nadzwyczaj bujna wyobraźnię. Jego umysł zawsze był przepełniony tysiącami projektów, co sprawiało, że nigdy nie mógł usiedzieć $\mathrm{w}$ jednym miejscu. Zawsze był w ruchu, trawiony gorączką działania i wiecznym niepokojem duszy. Nic nie było w stanie przykuć jego uwagi na dłużej. Szybko nauczył się ukrywać swoje prawdziwe uczucia, początkowo w obawie przed surowa i despotyczna matka, później zaś ze względu na docierające także na dwór królewski echa intryg politycznych i gwałtownych walk partyjnych, tak charakterystycznych dla szwedzkiej „epoki wolności”. Następca szwedzkiego tronu (od 1751 r.) otrzymał bardzo staranną edukację. Uczył się łaciny, greki, języka francuskiego, historii, matematyki, etyki oraz prawa naturalnego, zwyczajowego i państwowego. Co prawda, mały królewicz był uczniem bardzo niesystematycznym, nie przykładał się zbytnio do nauki i nie osiagał sukcesów w dziedzinach, które go nie interesowały, ale wiele czasu poświęcał na studia historyczne i naukę języka francuskiego. Bardzo wcześnie zaczą też zdradzać głębokie zainteresowanie literatura, teatrem i sztukami plastycznymi. Matka i kolejni guwernerzy sprawili, że Gustaw został wychowany w duchu francuskim. Interesował się literatura i filozofią francuskiego oświecenia. Wiele czytał. Posiadał ogromna bibliotekę, do której sprowadzał najnowsze wydawnictwa. Zapa-

7 Por. Z. Anusik, Dyplomacja szwedzka wobec kryzysu monarchii we Francji $w$ latach 1787-1792, Łódź 2000; id e m, France in Sweden's Foreign Policy in the Era of Gustav III's Reign 1771-1792, Łódź 2016. 
trzony we wzory wersalskie, rozczytujący się w dziejach panowania królów Francji - Henryka IV i Ludwika XIV, podziwiający dokonania Gustawa Wazy, Karola XII i - przede wszystkim - Gustawa II Adolfa, szwedzki kronprins od wczesnej młodości marzył też o znaczącym wzmocnieniu władzy królewskiej we własnym kraju ${ }^{8}$.

Dnia 12 lutego 1771 r. nagle zmarł król Szwecji Adolf Fryderyk. W tym czasie królewicz Gustaw odbywał podróż po krajach Europy Zachodniej. Wiadomość o śmierci ojca dotarła do niego 1 marca w Paryżu (przebywał tam incognito, jako hrabia Gotlandii). Na francuskim dworze zaplanowany też został monarchistyczny zamach stanu i przed wyjazdem $z$ Paryża nowy władca Szwecji otrzymał zachętę do obalenia siłą obowiązującej w jego kraju konstytucji. Dopiero w początkach marca 1772 r., po długotrwałych kłótniach między szlachta i trzema stanami nieuprzywilejowanymi, riksdag uzgodnił treść zobowiązań królewskich Gustawa III, których przyjęcie było warunkiem sine qua non jego formalnego wyniesienia na tron. Dnia 4 marca Gustaw podpisal swoje zobowiazania, nie zadajac sobie nawet trudu ich uważnej lektury, a 29 maja 1772 r. koronował się uroczyście w sztokholmskim Storkirkan. Nie zmieniło to jednak w niczym jego pozycji w państwie i nie doprowadziło do zwiększenia jego wpływu na przebieg obrad riksdagu. Tymczasem zaś ster rząów w Szwecji uchwyciła, wspierana przez dwór petersburski, reprezentująca interesy stanów nieuprzywilejowanych, partia „czapek”. Popierana przez większość szlachty, profrancuska partia „kapeluszy” znalazła się w stanie całkowitego rozkładu. Gustaw III nie zamierzal rzecz jasna tolerować rząów nielubianych przez siebie „czapek” i panoszenia się w Sztokholmie rosyjskiego ambasadora. Kiedy zdał sobie sprawę $z$ niemożności pogodzenia interesów stanu szlacheckiego $z$ dążeniami stanów nieuprzywilejowanych, podją decyzję o dokonaniu zamachu stanu. Rankiem 19 sierpnia 1772 r. Gustaw III wygłosił w zamkowej kordegardzie porywająca mowę do oficerów gwardii, którzy wraz $z$ dwiema kompaniami żołnierzy przeszli na stronę spiskowców. Gwardziści zajęli arsenał, aresztowali członków Rady Państwa

8 Por. B. Hennings, Gustav III som kronprins, Uppsala 1935, s. 20-98, 159184, 308-349; eadem, Gustav III. En biografi..., s. 12-38; A. Geffroy, op. cit., t. I, s. 74-101; R.N. Bain, op. cit., vol. I, London 1894, s. 13-27, 35-40, 216-220; C. Nordmann, op. cit., s. 27-29; Z. Anusik, Edukacja oświeconego księcia. Wychowanie $i$ wykształcenie szwedzkiego nasteppy tronu, królewicza Gustawa (późniejszego Gustawa III), [w:] Między barokiem a oświeceniem. Edukacja, wykształcenie, wiedza, red. S. Achremczyk, Olsztyn 2005, s. 260-279. 
i obsadzili wszystkie ważniejsze obiekty w mieście. Zamachowcy nigdzie nie napotkali najmniejszego nawet oporu. Przewrót odbył się bez rozlewu krwi, przy radosnej aprobacie mieszkańców stolicy. Przez dwa dni król w asyście oddziału gwardii jeździł po mieście, przemawiając do mieszkańców Sztokholmu i odbierając przysięgę wierności od wojska i różnych magistratur. Dnia 21 sierpnia 1772 r. Gustaw III zwołał na zamku królewskim plenarne posiedzenie riksdagu. Miejsce zebrania stanów otoczono wojskiem. Król wygłosił mowę, przedstawiając swoje stanowisko w sprawie przyczyn, które zmusiły go do obalenia dotychczasowego porządku siłą. Częściowo przekonane do królewskich racji, częściowo zaś sterroryzowane stany nie tylko wykonały przysięgę na wierność władcy, ale nawet wysłały do niego deputację $z$ podziękowaniem za wydobycie królestwa $z$ anarchii. Jeszcze tego samego dnia członkowie riksdagu zaakceptowali w całej rozciagłości upadek dotychczasowego systemu rządów, uchwalając przedstawiony im przez króla projekt nowej konstytucji. W ten oto sposób bezkrwawy zamach stanu zakończył w dziejach Szwecji „epokę wolności”9.

Monarchistyczny zamach stanu $z$ sierpnia 1772 r. zapoczątkował nowa epokę w dziejach Szwecji. Oktrojowana przez Gustawa III nowa konstytucja (forma rządu) przeobraziła gruntownie ustrój polityczny królestwa. Stronnictwa „czapek” i „kapeluszy” zniknęły ostatecznie ze sceny politycznej. Partiom zakazano wszelkiej działalności. Młody król nie wprowadził jednak pełnej autokracji. Uznał, że lepiej będzie podzielić się władzą ze swoim narodem. Jego marzeniem było bowiem odnowienie w Szwecji instytucji po-

${ }^{9}$ Por. C.T. O d h n er, Sveriges politiska historia under konung Gustaf III:s regering, Bd I (1771-1778), Stockholm 1885, s. 11-13, 25-65, 89 n., 93 n., 114-154; A. Söderhjelm, op. cit., s. 36-37; A. Geffroy, op. cit., t. I, s. 107-125, 131-135, 137-144, 150-154, 156-158, 160-167; R.N. Bain, op. cit., s. 53-80, 90-91, 99100, 104-131; Y. Ro s a nder, Några brev från Gustav III och Charles de Vergennes till Fredrik Carl Sinclair under riksdagen 1771-1772, „Historisk Tidskrift”, Bd LXXIII, Stockholm 1953, s. 417-436; C.F. Sheridan, A History of the Late Revolution in Sweden, London 1788; C.G. Malmström, Sveriges politiska historia från konung Karl XII:s död till statshväfningen 1772, uppl. 2, Bd VI, Stockholm 1901, s. 344-411; H. Schück, Gustav III:s statsvälvning 1772 I berättande källor och äldre litteratur, Historisk Arkiv 4, Uppsala 1955; C. Nordman n, op. cit., s. 45-60; Z. Anusik, Gustav III's coup d'etat of 19 August 1772. The end of the "Age of Liberty” in Sweden, „Sarmatia Europea. Polish Review of Early Modern History" 2011/2012, vol. II, s. 47-64; id e m, Monarchistyczny zamach stanu Gustawa III z 19 sierpnia 1772 r. Geneza, przebieg, konsekwencje, „Przeglad Nauk Historycznych” 2013, R. XII, nr 1, s. 91-121. 
litycznych z czasów Gustawa II Adolfa. Konstytucja z 21 sierpnia 1772 r. była więc kompromisem między koncepcją oświeconego absolutyzmu a starymi szwedzkimi tradycjami parlamentarnymi. Funkcjonowanie narzuconego Szwecji ustroju zakładało harmonijna współprace powierzonej królowi władzy wykonawczej $z$ władzą ustawodawczą. Ta ostatnia została bowiem podzielona między stany i króla. Bez zgody riksdagu władca nie mógł nakładać żadnych podatków, rozpoczynać wojny ofensywnej i zmieniać oktrojowanej przez siebie konstytucji. W zgromadzeniu stanowym król dysponował jedynie prawem veta zawieszajacego, co zmuszało go do szukania w izbach poparcia dla przedstawianych im propozycji legislacyjnych. Gustaw III, dla którego ideałem ustrojowym była oświecona monarchia absolutna, był wyznawca zasady, że równowaga polityczna opiera się na hierarchicznym układzie społecznym. Uważał, że sojusz korony ze szlachtą jest zasadniczym elementem politycznej i społecznej stabilności Szwecji. Niemal od początku swoich rządów, kokietując i otaczając protekcją przedstawicieli stanu szlacheckiego, zmierzał jednak konsekwentnie do tego, aby przekształcić szwedzką arystokrację w zależną od siebie szlachtę dworską i uczynić $z$ niej rodzaj pretoriańskiej gwardii monarchii. Narastająca z czasem opozycję stanów nieuprzywilejowanych rozbrajał zaś zręcznie przez systematyczne uszlachcanie jej potencjalnych przywódców. Prawdziwym paradoksem było w tej sytuacji to, że arystokracja i szlachta stanowiły w Szwecji najbardziej republikańską i najbardziej konserwatywną siłę polityczna, która w przyszłości okazać się miała największą przeszkodą na drodze do realizacji rozległych planów politycznych Gustawa III ${ }^{10}$.

Wkrótce po dokonaniu zamachu stanu król przystapił do gruntownej reformy struktur politycznych i społeczno-gospodarczych rządzonego przez siebie państwa. Warto zwrócić w tym miejscu uwage na to, że o ile w polityce zagranicznej Gustaw III nawiązy-

${ }_{10}$ Por. H.A. Barto n, Gustav III of Sweden and the Enlightenment, „Eighteenth Century Studies. An Interdisciplinary Journal”, vol. VI, No. 1, Berkeley (University of California) 1972-1973, s. 11-12; ide m, Scandinavia in the Revolutionary Era 1760-1815, Minneapolis 1986, s. 82-83, 99-100; D. Michellessi, Rewolucya szwedzka sprawa Gustawa III, dzisiejszego króla szwedzkiego w roku 1772 utworzona, z przydatkiem formy nowego rzadu y pism zaciagajacych się do tey odmiany, przez... napisana, a z francuzkiego na oyczysty (j)ęzyk przełożona, Warszawa 1778, s. 102-159; W. Coxe, Travels into Poland, Russia and Denmark, vol. IV, London 1787, s. 429-447; C.T. Odhner, op. cit., s. 155-157; Z. Anusik, Dyplomacja..., s. 56-60; ide m, France..., s. 43-46. 
wał wyraźnie do programu stronnictwa „kapeluszy”, to w polityce wewnętrznej był raczej kontynuatorem działań zainicjowanych w okresie rządów partii „czapek”. W przeciagu stosunkowo krótkiego okresu król i jego ministrowie dokonali sanacji finansów publicznych. Przeprowadzili wielką reformę monetarna, uzdrowili skorumpowany i nieefektywny wymiar sprawiedliwości. Działania rządu doprowadziły do powściagnięcia nadużyć ze strony biurokracji. Przeprowadzono też reformy w armii, która była lepiej uzbrojona i lepiej dowodzona niż w poprzednim okresie. Zreorganizowana flota wojenna była również flotą na miarę potrzeb i możliwości państwa. Również stan gospodarki był więcej niż zadowalający. Nie dziwi więc to, że na riksdagu obradującym na przełomie 1778 i 1779 r., mimo ujawnienia się stosunkowo silnej opozycji w Izbie Rycerskiej, król przeforsował wszystkie swoje propozycje legislacyjne. Riksdag ten okazał sie jednak przełomowym momentem w dziejach panowania Gustawa III. W marcu 1779 r. nastąpiła diametralna zmiana nastroju władcy, który zaczął się skłaniać do mistycyzmu i wolnomularstwa. W tym samym czasie monarcha stracił też sporo wcześniejszego entuzjazmu dla reform wewnętrznych. Były one co prawda nadal kontynuowane, ale ich tempo znacznie osłabło. W pierwszej połowie lat osiemdziesiatych Gustaw III dokonał również wymiany swoich najbliższych współpracowników. Starych ministrów, którzy swoje polityczne doświadczenie zdobywali jeszcze w „erze wolności”, zastapili ludzie, którzy swoje wyniesienie zawdzięczali wyłącznie królowi. Załamanie się koniunktury gospodarczej i fala nieurodzajów, które nawiedziły w tym samym czasie Szwecję, zachęciły przedstawicieli różnych grup społecznych do wyrażania swojego niezadowolenia $z$ polityki rządu. Najgroźniejsza dla króla i jego nowych doradców była jednak coraz bardziej widoczna opozycja ze strony szlachty, która doszła do wniosku, że na rewolucji 1772 r. więcej straciła niż zyskała. W zamian za utratę dawnych wpływów politycznych nie otrzymała bowiem w istocie żadnych nowych korzyści. $Z$ niepokojem obserwowała też podejmowane przez rząd reformy, obawiając się dalszego osłabienia własnej pozycji na rzecz trzech niższych stanów. $Z$ tego właśnie powodu szlachta domagała się od króla ścisłego przestrzegania zasad konstytucji sierpniowej i niechętnie patrzyła na absolutystyczne tendencje w jego polityce. Mimo narastającej od dłuższego czasu krytyki poczynań rządu i powszechnego prawie niezadowolenia, najbliżsi współpracownicy Gustawa III przekonali 
go do zwołania riksdagu na maj 1786 r. I chociaż po bardzo burzliwych debatach stany ostatecznie uchwaliły podatki nadzwyczajne na najbliższe cztery lata, to w siedem tygodni po rozpoczęciu jego obrad król był zmuszony rozwiązać riksdag. W czasie tego zgromadzenia stanów władca został pobity na wszystkich polach. Nie udało mu się przeforsować żadnej ze zgłoszonych przez rząd propozycji legislacyjnych. Co jednak $z$ jego punktu widzenia było najgorsze, po rozwiąaniu riksdagu w kasie państwowej było mniej pieniędzy niż przed jego rozpoczęciem ${ }^{11}$.

Z riksdagu 1786 r. Gustaw III wyciagną̧ jeden ważny wniosek. Zdał sobie sprawę $z$ tego, że chcac skutecznie rządzić krajem, musi podzielić opozycję i doprowadzić do izolacji szlachty. Już w czerwcu tego roku zredukował więc chłopom o 1/4 wysokość podatków uchwalonych przez riksdag. Odrzucił też pomysł wprowadzenia monopolu tytoniowego, czym pozyskał sobie mieszczaństwo. Uporządkował również sprawy Kościoła, gdzie powściagnnięto wreszcie nadużycia i korupcję. Stopniowo jednak król stawał się coraz większym autokratą. Po niepowodzeniach doznanych na ostatnim riksdagu zraził się definitywnie do koncepcji współpracy rządu $z$ przedstawicielstwem stanowym i zmierzal prosto do władzy absolutnej, nie oglądając się na postanowienia zaprzysiężonej przed 14 laty konstytucji. W listopadzie 1786 r. zdymisjonował szefa resortu finansów - Johana Liljencrantza, ostatniego ministra ze starej szkoły politycznej. Jego następca został baron Eric Ruuth. Był on tylko narzędziem w rękach króla, który od tej pory sam

11 Por. C.T. Odhner, op. cit., Bd I, s. 345 n., 348 n., 352-381, 430 n., 436454, 459-471, 476-478, 537-579; Bd II (1779-1787), Stockholm 1896, s. 2-20, 47 n., 97 n., 189 n., 194 n., 210 n., 216 n., 223 n., 239 n., 374, 378 n., $417-$ 474, 480 n.; H.A. Barto n, Scandinavia..., s. 101-103, 105, 111-113, 134-139; i d e m, Gustav III..., s. 16-17, 19-20, 25; R.N. Bain, op. cit., s. 165-172, 176-177, 179-190, 225-228, 277-291; G. Maj ew s ka, Polityka handlowa Szwecji w latach 1720-1809, Wrocław 1991, s. 40-43, 99-102; Å.W. Es s e n, Johan Liljencrantz som handelspolitiker. Studier $i$ Sveriges yttre handelspolitik 1773-1786, Lund 1928; K. Aw e bro, Gustaf III:s räfst med ämbetsmännen 1772-1779 - aktionerna mot landshövdingarna och Göta hovrätt, „Acta Universitatis Upsaliensis”, Studia Historica Upsaliensia 96, Uppsala 1977; E. Anners, Humanitet och rationalism. Studier i upplysningstidens stafflagsreformer - särskild med hänsyn till Gustaf III:s reformlagstiftning, Lund 1965; Z. An u sik, Dyplomacja..., s. 60-66, 87-98; i d e m, France..., s. 46-52, 71-80; G. La nd be rg, Den svenska riksdagen under den gustavianska tiden, [w:] Sveriges riksdag. Historisk och statsvetenskapling främställning, Bd VII, Stockholm 1932, s. 39-76; C.F. Wae rn, 1786 års riksdag, [b.m.] 1868; E. Lönn roth, Gustavus III of Sweden: the Final Years. A Political Portrait, [w:] ide m, Scandinavians. Selected Historical Essays, Göteborg 1977, s. 103. 
zarządzał własnymi finansami. W 1787 r. władca podjął decyzję o przywróceniu domowej destylacji wódki. Została ona przyjęta wręcz entuzjastycznie przez większość ludności chłopskiej. W ten sposób spełniło się marzenie Gustawa III o pozbawieniu stanu szlacheckiego wsparcia politycznego ze strony nieuprzywilejowanych. W związku $z$ postanowieniem dotyczacym przywrócenia prawa do domowego pędzenia samogonu król napisał do swego najbliższego doradcy, generała Johanna Christophera Tolla: „Mariaż chłopstwa ze szlachetnie urodzonymi został więc teraz rozerwany i choćby $z$ tego powodu jest to przedsięwzięcie bardzo dla nas użyteczne". $Z$ punktu widzenia rządu rozbicie wspólnego frontu opozycji było zadaniem o pierwszorzędnym znaczeniu. U schyłku 1786 r. król i Toll podjęli już bowiem przygotowania do rozpoczęcia działań wojennych. Gustaw III wcale nie ukrywał zreszta swoich zamiarów. W czasie jednej z uroczystości dworskich powiedział bowiem: „Szwedzi wydają się być zmęczeni łagodnymi i pokojowymi rządami i zaczynaja tęsknić za bardziej surowym traktowaniem. Gdybyśmy mieli wojnę, mogliby się stać bardziej ulegli. I kto wie, może któregoś dnia dojdzie do spełnienia ich oczekiwań?”. Król nie mówił jednak całej prawdy. Decyzja o rozpoczęciu wojny już zapadła. Teraz król i jego najbliżsi współpracownicy czekali tylko na pierwsza sprzyjająca okazję. Czynili też goraczkowe poszukiwania, by znaleźć sobie odpowiedniego przeciwnika ${ }^{12}$.

Rzecz jasna, w tej kwestii wiele zależeć miało od rozwoju sytuacji na arenie międzynarodowej oraz od postawy Francji, jedynego w owym czasie sojusznika dworu sztokholmskiego. Trzeba bowiem pamiętać o tym, że to właśnie dwór wersalski rozwiną zakrojoną na szeroka skalę akcję dyplomatyczna, aby po zamachu $z 19$ sierpnia 1772 r. nie dopuścić do interwencji w Szwecji ze strony Rosji, Prus i Danii, które to państwa były gwarantami obalonej wówczas przez Gustawa III „wolnościowej” konstytucji. Kiedy jednak jesienią 1772 r. dwór sztokholmski przedstawił w Wersalu projekt szwedzko-francuskiego traktatu sojuszniczego, nie zyskał on akceptacji ze strony ministrów Ludwika XV. Zamiast aliansu dwór wersalski zaoferował Szwedom, podpisany ostatecznie w Paryżu 27 lutego

12 Por. C.T. Odhner, op. cit., Bd II, s. 485 n., 495 n., 500 n., 519; R.N. Bain, op. cit., vol. II, s. 5-6, 8-9; H.A. B a r to n, Scandinavia..., s. 140; i d e m, Gustav III..., s. 24; A. Geffroy, op. cit., t. II, s. 65; Hedvig Elisabeth Charlottas dagbok, utg. av C.C. Bonde, Bd II, Stockholm 1903, s. 182-183; Z. Anusik, Dyplomacja..., s. 98-100; id e m, France..., s. 80-82. 
1773 r., tajny traktat subsydiowy. Układ ten (zawarty na trzy lata) przewidywał wypłaty francuskich subwencji dla skarbu szwedzkiego w wysokości 800 tys. liwrów rocznie. Niedopuszczenie do obcej interwencji w Szwecji było niewattpliwym sukcesem gabinetu Ludwika XV. Gustaw III nie wydawał się specjalnie uszczęśliwiony takim rozwojem wydarzeń. Płonął bowiem chęcia zadziwienia całego świata wieściami o swoich sławnych czynach. Nie mogac na razie urzeczywistnić swoich marzeń o zwycięskiej wojnie i rozszerzeniu terytorium własnego państwa, skoncentrował się na zacieśnieniu związków z Francją. Dnia 10 maja 1774 r. zmarł jednak Ludwik XV, a na tron wstąpił jego dwudziestoletni wnuk, Ludwik XVI. Jednym $z$ jego pierwszych kroków było zdymisjonowanie ministrów poprzedniego władcy. Wywołało to poważny niepokój dworu sztokholmskiego. Na szczęście dla Gustawa III gabinet francuski nie zamierzał niczego zmieniać w swojej dotychczasowej polityce wobec Szwecji. Nowym ministrem spraw zagranicznych Francji został bowiem jej dotychczasowy ambasador w Sztokholmie, współtwórca sierpniowego zamachu stanu, Charles Gravier hrabia de Vergennes. Potwierdzeniem tego, że dwór wersalski zamierza kontynuować dotychczasowa linię polityczną, było przedłużenie w dniu 25 września 1775 r. traktatu subsydiowego ze Szwecja na kolejne trzy lata. Układ ten wszedł w życie 1 stycznia 1776 r. i zapewnił dworowi sztokholmskiemu środki niezbędne do kontynuowania dzieła reform i uzdrawiania finansów publicznych ${ }^{13}$.

Gustaw III był jednak dla Francji trudnym partnerem. Niemal bez przerwy podejmował bowiem próby wyzwolenia się spod kurateli Vergennesa i zaktywizowania własnej polityki zagranicznej. W 1777 r., wbrew woli francuskiego sojusznika, pojechał do Petersburga na spotkanie $z$ Katarzyna II. Nie udało mu się jednak doprowadzić do polepszenia stosunków z Rosją i rozbicia jej sojuszu z dworem kopenhaskim. W 1778 r. szykował się z kolei do wojny z Danią. Rozważał też pomysł odebrania biskupstw Bremen i Werden elektorowi Hanoweru, który zasiadał jednocześnie na

${ }^{13}$ Por. A. Geffroy, op. cit., t. I, s. 169-183, 204-287, 305, 312; R.N. Bain, op. cit., vol. I, s. 135-136, 196-198; A. Söderhjelm, op. cit., s. 40, 43-44; A.J. Hje1t, Sveriges ställning till utlandet närmast efter 1772 års statshwälfning, Helsingfors 1887; Projet d'un traité d'alliance entre le Roi Trés Chrètienne et le Roi de Suède, (8bre 1772), Riksarkivet w Sztokholmie [dalej: RA], Gallica vol. 555, karty bez paginacji (uwaga ta dotyczy wszystkich innych, przywoływanych niżej zbiorów Riksarkvet); Z. An us ik, Dyplomacja..., s. 72-80. 
tronie angielskim jako Jerzy III. Dnia 2 grudnia 1778 r. król Szwecji zawarł w Wersalu nowa konwencję subsydiową z Francją. Układ ten obligował dwór wersalski do wypłacania Szwedom 1,5 mln liwrów rocznie, w ratach kwartalnych, przez sześć lat. Mimo wyraźnego sprzeciwu Charles'a de Vergennesa, który konsekwentnie odwodził Gustawa III od pomysłów zaatakowania któregoś z sąsiadów, w 1783 r., licząc na to, że kryzys krymski doprowadzi do wybuchu wojny rosyjsko-tureckiej, władca Szwecji ponownie usiłował sprowokować konflikt zbrojny $z$ Danią. W czerwcu tego roku raz jeszcze spotkał się $z$ Katarzyna II, ale i tym razem nie udało mu się rozbić jej przymierza $z$ dworem kopenhaskim. W latach 1783-1784 Gustaw III odbył podróż po krajach Zachodniej Europy. Jej celem było znalezienie sojusznika, który byłby gotów udzielić mu pomocy w wojnie przeciwko Danii. Fiasko tych zabiegów zmusiło go do odnowienia starych związkow z dworem wersalskim. Dnia 19 lipca 1784 r. Gustaw III i Ludwik XVI złożyli swoje podpisy na tajnej konwencji o przyjaźni i subsydiach. Układ ten miał obowiązywać przez pięć lat, a Szwecja, oprócz zwykłych subsydiów w wysokości 800 tys. liwrów rocznie, miała otrzymać dodatkowo 6 mln liwrów, wypłacanych w ratach miesięcznych po 100 tys. liwrów, poczynając od 1 lipca 1784 r. Gustaw III wyjeżdżał z Francji jako prawdziwy triumfator. Podbudowany zaś sukcesem osiagniętym w Wersalu, od chwili swojego powrotu do Sztokholmu wyraźnie zmierzał do rozpętania konfliktu zbrojnego ${ }^{14}$.

W pierwszym rzędzie rozważał możliwość uderzenia na Danię. Później zwrócił uwage na rozwój sytuacji w Holandii, która zmierzała prosto ku wojnie domowej. $Z$ Republika Zjednoczonych Prowincji zamierzał związać się traktatem sojuszniczym, oferując jej pomoc wojskowa w zamian za solidne subsydia. Ostatecznie rozpoczą jednak przygotowania do wojny z Rosją. Zaraz po zakończeniu

14 Por. C.T. Odhner, op. cit., Bd I, s. 394-397, 485-486; Bd II, s. 235 n., 242 n., 245 n., 254 n., 265-267, 271-291 n., 320 n.; id e m, Gustaf III och Katarina II åren 1783-1784, Stockholm 1879; R.N. Bain, op. cit., vol. I, s. 199-209, 211, 259-260, 264-276; O. J ä ge r s kiöld, Den svenska utrikespolitikens historia, Bd II, del. 2 (1721-1792), Stockholm 1957, s. 272, 278; A. Söderhjelm, op. cit., s. 43, 45-46, 48-50; Z. Anusik, Dyplomacja..., s. 85-87, 102-103, 109-119; i d e m, France..., s. 83-98; S. O a kley, Gustavus III:s Plan for War with Denmark, 1783-84, [w:] Studies in Diplomatic History, eds R. Hatton, M.S. Anderson, London 1970, s. 168-186; A. Geffroy, op. cit., t. II, s. 25-41, 46; H. Stålhane, Gustaf III:s resa till Italien och Frankrike, Stockholm 1953; Pacte d'union entre S.M. le Roi de Suède et S.M. Trés Chrètienne fait à Versailles le 19 Julliet 1784 (copie), RA, Gallica vol. 558. 
riksdagu 1786 r. udał się na spotkanie z duńską rodziną królewską, podejmując nieudana próbę nakłonienia dworu kopenhaskiego do zerwania sojuszu z Rosją. Kiedy zaś w sierpniu 1787 r. wybuchła wojna rosyjsko-turecka, Gustaw III postanowił skorzystać z nadarzającej się okazji do zbrojnego wystapienia przeciwko dworowi petersburskiemu. W październiku tego roku ponownie odwiedził Kopenhagę, starając się uzyskać zapewnienie, że Dania zachowa neutralność w wypadku wybuchu wojny szwedzko-rosyjskiej. Był to jednak cel niemożliwy do osiagnięcia. Tymczasem narastające trudności wewnętrzne skłoniły władcę Szwecji do przyśpieszenia przygotowań wojennych. Szwedzkie zbrojenia nie uszły uwagi dworu wersalskiego, który jak zawsze dotąd starał się pohamować wojownicze zapędy Gustawa III. Nowy szef dyplomacji francuskiej - Armand Marc de Montmorin (Charles de Vergennes zmarł 1 lutego 1787 r.) ostrzegał władcę Szwecji, że jeśli rozpocznie wojnę bez zgody Francji, nie będzie mógł się spodziewać żadnej pomocy z jej strony ${ }^{15}$.

Mimo zdecydowanego sprzeciwu ze strony dworu wersalskiego, w końcu czerwca 1788 r. Gustaw III sprowokował incydent na granicy $z$ Rosją i oskarżając dwór petersburski o wywołanie konfliktu (konstytucja sierpniowa zabraniała mu wypowiadania wojny ofensywnej bez zgody riksdagu), rozpoczał działania wojenne. Po pierwszych niepowodzeniach doczekał się buntu w armii fińskiej i zawiązania przez ponad setkę oficerów konfederacji w Anjala. Zbuntowani oficerowie protestowali przeciwko rozpoczęciu wojny bez zgody riksdagu i oferowali królowi swoje pośrednictwo w rozmowach pokojowych $z$ Katarzyną II. W końcu sierpnia $1788 \mathrm{r}$. położenie Gustawa III było wręcz tragiczne. Zbuntowana armia pertraktowała $z$ carowa, flota została zablokowana przez eskadre rosyjska w Sveaborgu. Tak w Finlandii, jak i w Szwecji uaktywniła się szlachecka opozycja, której przedstawiciele domagali się bezzwłocznego przywrócenia pokoju $z$ Rosja, zwołania riksdagu i przestrzegania przez króla postanowień konstytucji z 1772 r. Rozbity psychicznie i złamany moralnie Gustaw III myślał nawet o abdykacji i osiedleniu się we Francji. Na razie jednak słał rozpaczliwe

${ }_{15}$ Por. C.T. Odhner, Sveriges..., Bd II, s. 347-348, 352-355, 366-367, 397, 475; Z. Anusik, Dyplomacja..., s. 119-124, 174-188; id e m, France..., s. 99-103, 150-162; H.A. Barton, Scandinavia..., s. 154-156; A. Söderhjelm, op. cit., s. 63-64, 79-80, 85; E. Lön n roth, op. cit., s. 103-106; G. Ry s tand, Varör krig? Nagot om bakgrund och „orsaker" till Gustav III:s ryska krig, [w:] Gustav III:s ryska krig, red. G. Artéus, Stockholm 1992, s. 9-22; O. Jägerskiöld, op. cit., s. 312, 315. 
apele o pomoc do dworów zagranicznych. Największe nadzieje wiązał początkowo $z$ dworami berlińskim i londyńskim. W połowie sierpnia $1788 \mathrm{r}$. na europejskiej scenie politycznej pojawiło się bowiem słynne trójprzymierze, czyli sojusz Wielkiej Brytanii, Prus i Holandii, gdzie interwencja wojsk pruskich doprowadziła do zwycięstwa Oranżystów i upadku partii republikańskiej szukającej oparcia we Francji. Nowy sojusz miał być przeciwwaga dla wojujących $z$ Turcją dworów cesarskich (Rosji i Austrii). Ostatecznie jednak Gustawa III uratował najazd wojsk duńskich, które w końcu września uderzyły na Szwecję. Ich marsz wstrzymała bowiem interwencja dyplomatów angielskich i pruskich, którzy już w początkach października doprowadzili do przerwania działań wojennych, a w listopadzie - do ewakuacji oddziałów duńskich. Zręcznie zaś operując hasłami walki z odwiecznym wrogiem, król zdołał zapewnić sobie poparcie trzech niższych stanów tak w walce z Duńczykami, jak i buntownikami ze stanu szlacheckiego. Na zwołanym w końcu stycznia 1789 r. riksdagu król dokonał rozprawy ze szlachecka opozycja. Dnia 20 lutego wydał rozkaz zatrzymania w areszcie domowym 19 liderów opozycji. Dzień później, 21 lutego riksdag przyjął przez aklamację ( $z$ wyraźnymi protestami ze strony szlachty) poprawkę do konstytucji zwana „Aktem jedności i bezpieczeństwa”. Zamach z 21 lutego 1789 r. oznaczał powrót do czasów królewskiego absolutyzmu. Jednocześnie jednak zniesienie większości przywilejów szlacheckich otworzyło droge do kształtowania się kapitalistycznych stosunków na wsi szwedzkiej. Warto więc zwrócić uwagę na paradoksalny fakt, że Gustaw III, w niedalekiej przyszłości jeden $z$ najbardziej zajadłych wrogów rewolucji francuskiej, w czasie obrad riksdagu 1789 r. otworzył droge do takich samych przemian natury społeczno-ekonomicznej, jakie już wkrótce miały zostać zapoczątkowane także we Francji. Dnia 28 kwietnia król rozwiązał riksdag, natomiast 11 maja 1789 r. zlikwidował Radę Państwa. Szwedzka arystokracja utraciła ostatni bastion swego wpływu i znaczenia w państwie. Od tej pory nikt nie miał najmniejszych nawet watpliwości, że cała władza została skoncentrowana w rękach monarchy ${ }^{16}$.

${ }^{16}$ Por. I. de Madariaga, Russia in the Age of Catherine the Great, New Haven-London 1981, s. 401-403, 409; H.A. Barto n, Scandinavia..., s. 156-163; R.N. Bain, op. cit., vol. II, s. 15-16, 22-37, 45-46; O. Jägerskiö1d, op. cit., s. 316; A. Söderhjelm, op. cit., s. 95, 101, 105; C.T. Odhner, op. cit., Bd III (1787-1788), Stockholm 1905, s. 62-65, 76-80, 93-95 n., 134 n., 139 n., 147 n., 157 n., 160 n., 236, 240-241, 259-261; A. Geffroy, op. cit., t. II, s. 68-69, 74-88; 
Od chwili wybuchu wojny szwedzko-rosyjskiej sytuacja wewnętrzna w ogarniętej coraz głębszym kryzysem Francji przestała być głównym obiektem zainteresowania dworu sztokholmskiego. Gustaw III patrzył na wydarzenia rozgrywajace się w tym kraju przez pryzmat własnych niepowodzeń wojennych. Od dworu wersalskiego oczekiwał regularnego wypłacania należnych mu subsydiów oraz interwencji dyplomatycznej w Petersburgu i w Kopenhadze. Kiedy zaś przekonał się, że Francja nie podejmie żadnych działań na jego korzyść, zdecydował się na zwrot w kierunku państw trójprzymierza. Objęcie urzędu generalnego kontrolera finansów przez Jacques'a Neckera nie wywarło większego wrażenia na Gustawie III. Nie wierzył bowiem ani w możliwość szybkiego przezwyciężenia kryzysu wewnętrznego we Francji, ani w to, że pod rządami nowego ministra dojdzie do zaktywizowania francuskiej polityki zagranicznej. Już 15 września 1788 r., informując swojego faworyta, zaufanego doradcy i przyjaciela Gustafa Mauritza Armfelta o wyniesieniu na pierwszy urząd ministerialny Neckera, król nie bez pewnej ironii zauważył: „Oto teść mojego ambasadora [Erika Magnusa Staëla von Holsteina - przyp. Z.A.] skarbnikiem króla Francji; na nieszczęście jednak skarb króla, mojego sojusznika, jest tak samo pusty, jak mój własny" ${ }^{17}$. Informowany na bieżąco przez dobrze poinformowanego Staëla von Holsteina o wypadkach rozgrywających się we Francji w latach 1788-1789, Gustaw III z coraz większym niepokojem przyjmował wieści napływające $z$ kraju

L. Ericson, Kriget till lands 1788-1790, [w:] Gustav III:s ryska..., s. 80-83; J. Glete, Kriget till sjöss 1788-1790, [w:] ibidem, s. 141-148; W. Th a m, Konung Gustaf III och rikets stander vid 1789 års riksdag, Stockholm 1866; C. Nordmann, op. cit., s. 175-192; J.P. Find eis e n, „Królewski rewolucjonista”. Król Gustaw III u progu kapitalistycznej przebudowy szwedzkiego system feudalnego (1771-1792), „Zapiski Historyczne” 1997, t. LXII, z. 2-3, s. 69-85; Z. A nu si k, Dyplomacja..., s. 188-205; id e m, France..., s. 162-177; id e m, Dwór sztokholmski wobec wydarzeń w Holandii w latach 1785-1787, [w:] Gdańsk - Polska - Europa. Praca zbiorowa ofiarowana profesorowi doktorowi habilitowanemu Władysławowi Zajewskiemu $w$ siedemdziesiata rocznice urodzin, red. Z. Kropidłowski, Gdańsk 2001, s. 87-101; idem, Geneza i początki wojny szwedzko-rosyjskiej (kampania 1788 r.) w świetle korespondencji Gustawa III, [w:] Między Zachodem a Wschodem, t. II (Studia ku czci profesora Jacka Staszewskiego), red. J. Dumanowski, B. Dybaś, K. Mikulski, J. Porazinski, S. Roszak, Toruń 2003, s. 43-62; idem, Przykład szwedzki - konfederacja z Anjala, [w:] Król a prawo stanów do oporu, red. M. Markiewicz, E. Opaliński, R. Skowron, Kraków 2010, s. 163-180.

17 Por. Gustaw III do G.M. Armfelta, Leksand 15 IX 1788, Konung Gustaf III:s bref till friherre G.M. Armfelt [dalej: Bref till Armfelt], utg. af E. Tegnér, [w:] Historiska Handlingar, Bd XII, Stockholm 1883, s. 39. 
rządzonego przez władcę, którego przez wiele lat uważał za swojego najbliższego sojusznika ${ }^{18}$.

Król Szwecji od dłuższego już czasu patrzył zresztą $z$ dezaprobata na postępowanie Ludwika XVI i jego ministrów tak w polityce wewnętrznej, jak i zagranicznej. Był oburzony nieotrzymaniem od dworu wersalskiego pomocy w wojnie przeciwko Rosji. Upust narastajacej od dawna frustracji dał jednak w chwili, kiedy dotarła do niego informacja, że ambasador francuski w Sztokholmie, markiz Louis Marc de Pons otrzymał od swojego ministra spraw zagranicznych rozkaz powrotu do Paryża. Zirytowany takim obrotem sprawy, w liście do sekretarza stanu Ulrica Gustafa Franca $z 15$ lipca 1789 r., Gustaw III poddał druzgocącej krytyce politykę Francji w ostatnich latach: „Nie wiem, czy najlepszym sposobem dla odzyskania przez nia dawnej pozycji jest zerwanie wszystkich starych sojuszów, jakie dwór wersalski zawarł na Północy. Odwołując swoja ambasadę ze Sztokholmu, Francja zrywa dawne więzi, które od zawsze istniały między naszymi królestwami. Po tym wszystkim powinna też zerwać pakt familijny domu Bourbonów [z Hiszpanią - przyp. Z.A.], i wówczas, całkowicie osamotniona, będzie mogła spokojnie pogrążyć się w wewnętrznej anarchii. Wszystko to razem odpowiednio upamiętni sławne panowanie Ludwika XVI i będzie szło w parze $z$ godnym podziwu potężnym wsparciem, jakiego Francja udzieliła Holandii przed dwoma laty. Serce mi pęka, gdy widzę tak piękne królestwo, tak okrutnie doświadczone w sferze polityki i finansów"19.

W poczatkach sierpnia do króla dotarły pierwsze wiadomości o wydarzeniach paryskich z 14 i 15 lipca. Wieści te wywołały u Gustawa III prawdziwa zgrozę i wielkie przygnębienie. W pisanym w dniu 7 sierpnia 1789 r. liście do generała Curta von Stedingka, który przez kilkanaście ostatnich lat służył we francuskim regimencie Royal Suédois, monarcha zdecydowanie potępił zarówno kapitulację Ludwika XVI wobec Konstytuanty, jak i jego decyzję

18 Por. Z. Anusik, Dyplomacja..., s. 209-226; idem, France..., s. 178-197; ide m, Wydarzenia we Francji w pierwszych miesiacach rewolucji (maj-październik 1789 r.) $w$ świetle doniesień ambasadora Szwecji w Paryżu (Wersalu) Erika Magnusa Staëla von Holsteina, „Przegląd Nauk Historycznych” 2016, R. XV, nr 1, s. $85-127$.

19 Por. Gustaw III do U.G. Franca, obóz pod Liikala 15 VII 1789, Kon. Gustaf III:s bref till Riks-Drotsen Grefve Axel Wachtmeister och Stats-Sekreteraren Ulric Gustaf Franc, efter handskrifter på Trolle-Ljungby [dalej: Bref till Wachtmeister och Franc], utg. af G. Andersson, Örebro 1860, s. 102. 
o wycofaniu wojska z Paryża. Oburzała go postawa władcy, który w chwili, kiedy „Stany ogłosiły, że ministrowie królewscy oraz urzędnicy cywilni i wojskowi sa odpowiedzialni za swoje czyny przed narodem, sam, w towarzystwie Monsieur [Ludwika hr. Prowansji - przyp. Z.A.] i hrabiego d'Artois, idac pieszo, bez świty, przybył do siedziby Zgromadzonych Stanów, czyniąc bez mała publiczna pokutę i proszac o pomoc w uśmierzeniu rozruchów. Oto, co się wydarzyło, i oto, w jaki sposób słabość, niepewność i nieroztropnie użyta przemoc doprowadzą w rezultacie do obalenia tronu Ludwika XVI"20. Następnego dnia, 8 sierpnia, Gustaw III napisał do swojego zaufanego doradcy i przyjaciela, Gustafa Mauritza Armfelta: „Ta biedna Francja! Ta biedna Francja! Jaka szkoda! Jestem w rozpaczy"21. Tego samego dnia, w liście do Ulrica Gustafa Franca, król wyraził następującą opinię o ostatnich wydarzeniach: „Nowiny z Francji wywołuja u mnie takie wzruszenie, jak gdyby dotyczyły mnie osobiście. Czuję niepokój, pomieszany $z$ największym żalem, mając na uwadze postępowanie i sytuację tego biednego króla, najlepszego człowieka na świecie i najbardziej nieodpowiedniego zarazem, aby rządzić tak wielkim państwem, zwłaszcza takim jak Francja. Jako człowiek, jestem bardzo poruszony okropnościami popełnionymi przez tych szalonych paryżan, a jako król jestem wzburzony niegodziwościami, których Francuzi dopuścili się wobec autorytetu królewskiego, formując armię niezależną od władcy i ustanawiając sobie namiestnika (tak nazywam nowego prewota kupców) [król miał na myśli mera Paryża - Jeana Sylvaina Bailly'ego - przyp. Z.A.], co było z pewnością obraźliwe dla monarchy. Dochodzą mnie również słuchy, że generał Paryża [dowódca gwardii narodowej - Marie Joseph de La Fayette - przyp. Z.A.] jest siostrzeńcem mojej dobrej przyjaciółki, pani de Boufflers, co dodatkowo rozdziera mi serce. Wysyłam do niej list przez barona de Staël. Jestem nieskończenie zadowolony $z$ jego postępowania i odkąd król jest niczym, a pan Necker wszystkim, powinien być on dla nas bardzo użyteczny". Co ciekawe, oburzony postępowaniem poddanych Ludwika XVI, Gustaw III zamierzał skorzystać z kłopotów swojego dawnego sojusznika. W dalszej części tego samego listu pisał bowiem, że doszły go słuchy, jakoby we Francji

${ }^{20}$ Por. Gustaw III do C. v. Stedingka, Kymmenegård 7 VIII 1789, cyt. według A. Söderhjelm, op. cit., s. 144.

${ }^{21}$ Por. Gustaw III do G.M. Armfelta, Kymmenegård 8 VIII 1789, Bref till Armfelt], s. 95. Por. też A. Söd e rhj elm, op. cit., s. 145; N. Åke s o n, op. cit., Bd I, s. 11. 
zamierzano zwolnić ze służby wszystkie oddziały niemieckie, które w dobie ogólnego chaosu i rozprzężenia dochowały wierności królowi. W związku z tym Gustaw III powiadomił sekretarza stanu, że chciałby przyjąć te oddziały do służby w armii szwedzkiej. Nie przewidywał specjalnych trudności, gdyż w jego opinii: „sam Necker oraz inni przywódcy ludu, którzy są nastawieni przeciwko Austrii, powinni być zainteresowani tym, żeby jak najszybciej pozbyć się tych oddziałów". Gdyby jednak Francuzi mieli jakieś opory $\mathrm{w}$ związku $\mathrm{z}$ realizacja tego projektu, to zawsze można by się powołać na traktat sojuszniczy z 1784 r., na mocy którego dwór wersalski powinien przysłać na pomoc Szwecji 12 tys. żołnierzy. Zdaniem króla to powinno być dla francuskiego ministerium dogodnym i wystarczającym pretekstem, żeby usunąc z kraju te niebezpieczne i niewygodne dla niego w danej chwili oddziały ${ }^{22}$.

Dnia 10 sierpnia 1789 r. Gustaw III otrzymał wiadomość o wizycie złożonej przez króla Francji w dniu 17 lipca w Paryżu. W związku $z$ tym napisał ponownie do Gustafa Mauritza Armfelta: „Rewolucja we Francji jest jednym $z$ najbardziej zadziwiających wydarzeń w historii; a ostatni krok króla, który osobiście przybył do paryskiego ratusza, potwierdzając i sankcjonując w ten sposób wszystkie nieprawości popełnione przez lud, jest sprawą tak dziwną, że mógłbym ja porównać tylko ze sprawą Henryka III $z$ czasów, kiedy ten nieszczęśliwy król podpisał, przez wzgląd na fałszywe kalkulacje polityczne, konfederację Ligi Katolickiej. Nicość obecnego króla ocali go być może przed tak fatalnymi następstwami, jakie krok ten przyniósł Henrykowi III. Niemniej jednak dla królestwa jego postępek jest zabójczy. Już wkrótce będzie tam bowiem rząd, jaki mieliśmy w Szwecji w 1720 r., który ustanowią, być może nawet wcale nie zdając sobie $z$ tego sprawy". W dalszej części tego listu król polecił Armfeltowi, aby dowiedział się, jak na ostatnie wydarzenia we Francji zapatruje się dwór madrycki. Prosił go także, by zbierał wszelkie informacje o wypadkach zachodzących w Paryżu, a także o losie królowej, „hrabiego d'Artois, który, jak mówia, znalazł ocalenie w Holandii", jak również o poczynaniach wszystkich tych osób, które maja jakikolwiek wpływ na Ludwika XVI i które będa mogły doprowadzić do zmiany jego ostatnich postanowień. Swoja negatywna opinię o władcy Francji Gustaw III potwierdził jeszcze raz stwierdzeniem, że „jest to naprawdę biedny król,

${ }^{22}$ Por. Gustaw III do U.G. Franca, Kymmenegård 8 VIII 1789, Bref till Wachtmeister och Franc, s. 114-115. 
w całym znaczeniu tego słowa" ${ }^{23}$. W pisanym tego samego dnia liście do Ulrica Gustafa Franca władca Szwecji powrócił do kwestii wynajęcia niemieckich oddziałów pozostających w służbie Francji: „Odkąd to królestwo uległo rozkładowi, jestem prawie pewien, że mój pomysł może zostać zrealizowany. Jedynie brak pieniędzy może nam w tym przeszkodzić. Właśnie przygotowałem depeszę do barona de Staël, którą prześlę panu otwarta, żeby skopiowano ja w biurze. W depeszy tej przedstawiam ambasadorowi szczegóły mojego planu”. Dalej król pisał w sposób następujący: „Tymczasem jest dla mnie sprawą interesujacca, jak król Hiszpanii zapatruje się na kwestię wywrócenia władzy monarszej we Francji i czy spowoduje to jakieś zmiany w hiszpańskiej polityce zagranicznej. Wiadomo mi bowiem, że dwór madrycki nie zgadzał się $z$ Wersalem w sprawie systemu austriackiego i jedynie obawa przed zerwaniem paktu familijnego powstrzymywała Hiszpanów przed przyjęciem całkiem innego systemu sojuszów. Jest bardzo możliwe, że obecne ministerium francuskie (powodowane choćby tylko niechęcia do królowej) zechce działać przeciwko interesom dworów cesarskich. To wszystko może doprowadzić do ustanowienia całkiem nowego porządku rzeczy, o niemożliwych do przewidzenia skutkach. Życzę więc sobie, aby przekazał pan moje uwagi ministrom w Madrycie, Paryżu, Londynie oraz w Berlinie. Chcę także, żeby rozkazał pan ministrowi w Wiedniu, aby sygnalizował nam najdrobniejsze nawet szczegóły dotyczące tego, co mówią na temat wydarzeń we Francji cesarz, [książę Wenzel Anton von - przyp. Z.A] Kaunitz i wszystkie inne znaczące osobistości dworu wiedeńskiego. Dzięki znajomości tych szczegółów będzie bowiem można w mniejszym lub większym stopniu wyrobić sobie opinię na temat tego, jaka wage przykładaja tam do tych ważnych wypadków”24. W przytoczonym wywodzie dwie sprawy zasługują na szczególne podkreślenie. Po pierwsze, przekonanie króla o antyaustriackim nastawieniu Neckera i ludzi,

${ }^{23}$ Por. Gustaw III do G.M. Armfelta, Kymmenegård 10 VIII 1789, Bref till Armfelt, s. 96. Por. też A. Söderhje1m, op. cit., s. 145.

${ }^{24}$ Por. Gustaw III do U.G. Franca, Kymmenegård 10 VIII 1789, Bref till Wachtmeister och Franc, s. 118. O reakcji Hiszpanów na wypadki lipcowe w Paryżu pisał w swojej depeszy z 3 VIII poseł szwedzki w Madrycie, Carl August Ehrensvärd. $Z$ jego relacji wynikało, że dwór hiszpański stara się odciąć społeczeństwo od wszelkich nowin docierających $z$ Francji, gdyż obawia się, żeby tamtejszy przykład nie przypomniał narodowi o istnieniu kortezów, do których Hiszpanie byli w przeszłości bardzo przywiązani. Por. C.A. Ehrensvärd do Gustawa III, Madryt 3 VIII 1789, apostille, RA, Hispanica vol. 31. 
których uważał za przywódców rewolucji francuskiej. Po drugie zaś, opinia, że wypadki we Francji doprowadzą do nieuchronnego przesilenia na arenie międzynarodowej. W obu sprawach przewidywania królewskie okazały się słuszne. Tyle tylko, że na ich spełnienie przyszło mu jeszcze długo poczekać.

Dnia 13 sierpnia 1789 r. Gustaw III w podobnym tonie pisał do Armfelta: „Z niecierpliwością oczekuje poczty, żeby poznać nowiny $z$ Francji. Ta zadziwiająca rewolucja $z$ pewnością wtrąci całą Europę w nowy chaos". Nie wydaje się jednak, by król specjalnie przejmował się ówczesnymi problemami Ludwika XVI. W tym samym liście zwierzał się bowiem swojemu faworytowi $z$ planów ściągnięcia do Szwecji francuskich aktorów, którzy w jego przekonaniu już wkrótce mieli utracić zatrudnienie w ogarniętym anarchią kraju. W tym samym czasie Gustaw III wpadł na pomysł zaproszenia do Sztokholmu francuskich emigrantów. W cytowanym liście do Armfelta znalazło się bowiem następujące stwierdzenie: „Zastanawiałem się i zastanawiam się nadal nad pokusa, aby zaoferować azyl hrabiemu d'Artois. Wydaje mi się bowiem, że jest moim obowiązkiem zainteresować się nieszczęściem wnuka Ludwika XV, a danie schronienia synowi Francji wydaje mi się czymś niezmiernie zaszczytnym"25. Kilka dni później Gustaw III otrzymał wiadomość o zamordowaniu przez lud Paryża 22 lipca kontrolera generalnego finansów - Josepha François Foullona, który zastapił zdymisjonowanego Neckera oraz jego zięcia, intendenta stolicy Louisa Bénigne de Bertiera. Nowina ta wywarła na nim wstrząsające wręcz wrażenie. Dnia 19 sierpnia 1789 r. pisał bowiem do Gustafa Mauritza Armfelta: „Nowiny $z$ Francji wprawiły mnie w takie przerażenie, że nie mogłem wcale zasnać tej nocy i usnąłem dopiero o 4 nad ranem. Tymczasem w noce poprzedzajace 17 lutego 1789 r. i 19 sierpnia 1772 r. spałem bardzo dobrze. Obawiam się ciagle, że zobaczę głowę pana Foullon, która ci łajdacy podają do pocałowania panu Bertier, jego zięciowi. I to ma być ten zachwycający Paryż, gdzie wszystkie narody Europy spotykały się po to, aby szukać przyjemności i znajdować pocieszenie dla swoich zmartwień! To ma być to miejsce, gdzie chcieliśmy się wycofać, jeśli zostalibyśmy stąd wypędzeni. Zaprawdę byłoby to, jak wpaść ze Scylli na Charybdę! Jacy okropni ludzie! To są orangutany (ludożercy) Europy. Dlaczego $z$ takim wdziękiem i uprzejmością łączy się tak zdumie-

${ }^{25}$ Por. Gustaw III do G.M. Armfelta, Kymmenegård 13 VIII 1789, Bref till Armfelt, s. 99. Por. też A. Söd erhjelm, op. cit., s. 146. 
wające wprost okrucieństwo?”26. Zadając Armfeltowi to pełne bólu pytanie, Gustaw III nie mógł nawet przypuszczać, o jaką rozpacz przyprawia go kolejne nowiny napływające ze stolicy Francji.

W swojej depeszy z Paryża z 29 sierpnia 1789 r. Erik Magnus Staël von Holstein zawarł następujace stwierdzenie: „Mamy wielkie szczęście Najjaśniejszy Panie, że nasze dawne związki polityczne $z$ Francją zostały zerwane. Należy bowiem uważać to państwo (jeżeli w ogóle kiedykolwiek wydobędzie się z okropnego kryzysu, w jakim obecnie się znajduje) za wykreślone na wiele lat $z$ rzędu mocarstw europejskich". Dnia 29 września depesza ambasadora dotarła do Gustawa III, przebywającego ówcześnie w fińskiej miejscowości Lovisa. Jeszcze tego samego dnia król sporządził na niej, przeznaczona dla Ulrica Gustafa Franca, notatkę: „Trzeba uprzedzić Staëla, żeby sporządził dla nas szczegółowy spis wszystkich przywódców różnych partii, $z$ informacja o ich projektach i ich talentach. Chcemy także jak najwięcej wiedzieć o aktualnej sytuacji króla, jego żony, braci oraz starych i nowych ministrów"27.

W tej sytuacji nie może dziwić to, że kiedy we wrześniu 1789 r. chargé d'affaires Francji w Sztokholmie, kawaler Jean de Gaussen przedstawił Gustawowi III propozycję mediacji Francji w rozmowach pokojowych $z$ Katarzyną II, król zdecydowanie odrzucił taką możliwość. Dnia 13 października władca Szwecji przekazał sekretarzowi stanu, Ulricowi Gustafowi Francowi pisemne dyspozycje dotyczące przygotowania odpowiedzi na notę złożona przez francuskiego dyplomatę. Król polecił oświadczyć Gaussenowi, że nie zakończy wojny z Rosją, zanim nie odniesie jakiegoś znaczącego zwycięstwa i nie zmusi cesarzowej do przyjęcia swoich warunków, którymi są: powstrzymanie ekspansji rosyjskiej przeciwko Turcji, przywrócenie starej granicy rosyjsko-szwedzkiej i powstrzymanie ingerencji Katarzyny II w wewnętrzne sprawy jego kraju. Ponieważ

${ }^{26}$ Por. Gustaw III do G.M. Armfelta, Kymmenegård 19 VIII 1789, Bref till Armfelt, s. 103. Por. też A. Söd erhjelm, op. cit., s. 146; N. Åke s o n, op. cit., Bd I, s. 11. W sprawie reakcji Gustawa III na wieści napływające $z$ Francji por. też E. Schröderheim, Skrifter till konung Gustaf III:s historia, utg. af E. Tegnér, uppl. 2, Stockholm 1892, s. 105; G.J. Adler beth, Historiska anteckningar. Efter en i von Brinkmanska Arkivet på Trolle-Ljungby befintlig handskrift, utg. af G. Andersson, Del. I, Örebro 1856, s. 75; Ögonvitten om Gustav III, utg. av B. Hennings, Stockholm 1960, s. 378.

27 Por. E.M. Staël v. Holstein do Gustawa III, Paryż 29 VIII 1789 oraz notatka Gustawa III na tej depeszy, RA, Gallica vol. 472. Por. też A. Söder hjelm, op. cit., s. 200 oraz Z. Anusik, Dyplomacja..., s. 226. 
zaś na razie nic nie wskazuje na to, by cesarzowa chciała zaakceptować żądania szwedzkie, wojna będzie kontynuowana. Król polecił także poinformować Gaussena, że mimo niechętnego stanowiska Francji Turcja zawarła formalny traktat ze Szwecją (11 lipca 1789 r. w Stambule), przyznając jej subsydia w wysokości $10 \mathrm{mln}$ piastrów, czyli 4 mln riksdalerów. Gustaw III rozkazał też Francowi, aby uzasadniając odmowę przyjęcia francuskiej oferty mediacyjnej, napisał, że sami Francuzi powinni najlepiej znać powody, dla których zmuszony został do zaakceptowania podobnej oferty złożonej mu przez trzy sprzymierzone dwory. Zrobił to bowiem tylko dlatego, że został porzucony przez swojego dawnego sojusznika i nie mógł liczyć na żadne posiłki z jego strony. Również francuskie ministerium, opanowane przez zwolenników Austrii, nie budziło w nim już takiego zaufania, jakie dawniej żywił wobec najdawniejszego alianta Szwecji. I jakie by nie były okoliczności zmuszające go do takiego postępowania, to nie on wycofał się $z$ sojuszu $z$ Francja. To Francja porzuciła bowiem swoje stare zasady i pierwsza wycofała się $z$ systemu, którego był gorącym zwolennikiem od $1768 \mathrm{r}$. i za utrzymaniem którego opowiadał się zawsze od tamtego czasu. Gustaw III kazał również Francowi zawrzeć w odpowiedzi dla Gaussena stwierdzenie, że nie byłoby ani mądrze, ani roztropnie ze strony króla, gdyby postanowił zrywać stosunki z dworami, które jako jedyne przyszły mu z pomoca, nie majac wobec niego jakichkolwiek wcześniejszych zobowiązań i które cały czas powstrzymuja Danię i nie dopuszczaja do realizacji jej wrogich zamiarów. Francja natomiast, nawet jeśli by chciała, nie byłaby w stanie skutecznie wspomóc Szwecji. Poza tym stan jej spraw wewnętrznych jest taki, że nie bardzo wiadomo, kto tak naprawdę tam rzadzi. W odpowiedzi wręczonej Gaussenowi miało się znaleźć również sformułowanie, że od współdziałania $z$ Francja króla powstrzymuje obawa, że wpływy Austrii mogłyby spowodować odwrócenie się dworu wersalskiego od Szwecji w decydujacym momencie wojny i mogłyby doprowadzić do tego, że Gustaw III ponownie znalazłby się na łasce Rosji. Treść dyspozycji królewskiej kłóciła się z poglądami samego sekretarza stanu, który wydawał się zwolennikiem utrzymania sojuszu $z$ dworem wersalskim, uważając go za bezinteresownego przyjaciela Szwecji, który nie żąda za swoja przyjaźń ani szwedzkiego handlu, jak Anglia, ani Pomorza, jak Prusy. Wyjaśniając Francowi motywy swojego postępowania Gustaw III, napisał więc do niego: „Francja jest obecnie niczym. Nie zamierzam być przyjacielem tej 
ciżby demagogów, którzy zebrali się w Wersalu, a Ludwik XVI jest takim zerem, jak pozbawiony wszelkiego znaczenia doża wenecki". Swoją opinię potwierdził następnego dnia, 14 października 1789 r., gdy na depeszy sekretarza stanu z 30 września zanotował: „Pan de Gaussen jest godnym reprezentantem swojego króla, który nie ma za grosz zdrowego rozsądku. Wyrzekłem się Francuzów i Francji, odkąd stała się ona oligarchiczna i republikańska. Jeśli bowiem chodzi o republikanów, to zdecydowanie bardziej wolę Anglików"28.

Dnia 11 listopada 1789 r. Gustaw III otrzymał wiadomość o październikowych wypadkach w Wersalu i w Paryżu (marsz kobiet na Wersal i przeniesienie siedziby dworu i Konstytuanty do Paryża). Tego samego dnia przygotowal stosowne rozkazy dla Ulrica Gustafa Franca. Nakazał mu zapewnić kawalera Jeana de Gaussena, że jest bardzo zmartwiony tym, co zdarzyło się w Paryżu. Sekretarz stanu miał także przekonać francuskiego dyplomatę, że Gustaw III jest żywo zainteresowany wszystkim, co dotyczy osoby króla Francji i gdyby nie był tak zaangażowany w wojnę $z$ Rosją, nigdy nie zostawiłby swojego starego przyjaciela na pastwę losu ${ }^{29}$. W chwili sporządzania cytowanej notatki władca Szwecji niewiele mógł jednak zrobić dla Ludwika XVI. Po skończonej kampanii 1789 r. wracał bowiem do Sztokholmu tylko po to, by podjać przygotowania do działań wojennych w następnym roku.

W kolejnych miesiaccach Gustaw III pochłonięty był innymi sprawami. Niemniej jednak znajdował czas na studiowanie depesz nadsyłanych $z$ Paryża przez Erika Magnusa Staëla von Holsteina. $Z$ biegiem czasu król tracił jednak stopniowo zaufanie do swojego ambasadora, który zdawał się sprzyjać zmianom, jakie dokonywały się we Francji w pierwszej fazie rewolucji. W pierwszych miesiącach 1790 r. coraz większy wpływ na króla wywierali zdeklarowani wrogowie rewolucji - generał Evert Taube i przyjaciel francuskiej pary królewskiej Hans Axel von Fersen. Również na dworze sztokholmskim coraz większe wpływy uzyskiwali przeciwnicy rewolucyjnej Francji. Niechętni rewolucji byli zaś bez wyjątku najbliżsi współ-

28 Por. Notatki Gustawa III na depeszach U.G. Franca z 26 i 30 IX 1789, Lovisa 13 i 14 X 1789, Bref till Wachtmeister och Franc, s. 146-148.

${ }^{29}$ Por. Notatka Gustawa III na depeszy U.G. Franca z 28 X 1789, Borgå 11 XI 1789, Bref till Wachtmeister och Franc, s. 151. Warto w tym miejscu wspomnieć, że królewskie obawy o los Francji w pełni podzielał jego dawny przyjaciel i minister spraw zagranicznych - Ulrik Scheffer. Por. U. Scheffer do S. Piper, Ek 8 XI 1789, B. Hennings, Ulrik Scheffer brev till Sophie Piper, „Historisk Tidskrift” [Stockholm] 1959, Bd LXXIX, s. 292. 
pracownicy Gustawa III w resorcie spraw zagranicznych: sekretarz stanu Ulric Gustaf Franc, sekretarz Biura Prezydialnego Pehr Olof von Asp i jego pierwszy zastępca baron Schering Rosenhane ${ }^{30}$.

Po udanej kampanii 1790 r. Gustaw III zawarł pokój z Rosją (14 sierpnia w Värälä). Przewidywał on zakończenie wojny na zasadzie status quo ante bellum, milcząco likwidował rosyjska gwarancję dla ustroju Szwecji sprzed 1772 r. i oznaczał de facto uznanie przez dwór petersburski nowelizacji szwedzkiej konstytucji dokonanej w lutym 1789 r. Obie strony były niemal w równym stopniu zadowolone $z$ podpisanego układu. Katarzyna II odzyskała bowiem swobodę ruchów w stosunku do Turcji i znacznie wzmocniła swoja pozycję przetargową $\mathrm{w}$ rokowaniach $\mathrm{z}$ państwami trójprzymierza. Gustaw III zaś, wychodząc obronną ręką z konfliktu, który od początku przybrał dla niego bardzo niekorzystny obrót, mógł skoncentrować swoją uwagę na innych problemach polityki europejskiej. Dla wielu obserwatorów było sprawą oczywistą, że głównym obiektem jego zainteresowania wkrótce stanie się Francja. Wszystko zdawało się też wskazywać na to, że głównymi doradcami króla w sprawach francuskich będą konserwatyści w rodzaju Everta Taubego i Hansa Axela von Fersena, a nie liberałowie pokroju Erika Magnusa Staëla von Holsteina ${ }^{31}$.

Po zawarciu pokoju w Värälä Gustaw III starał się nie tracić $z$ pola widzenia tego, co działo się we Francji. Jeśli nie podejmował na razie żadnych poważniejszych działań wobec tego kraju, to tylko dlatego, że musiał się uporać $z$ rozwiązaniem innych, pilniejszych $z$ jego punktu widzenia kwestii. Nie wzbudziły jego zainteresowania składane w sierpniu i wrześniu 1790 r. przez kawalera Jeana de Gaussena memoriały w sprawie uregulowania szwedzko-francuskich stosunków handlowych. Król nie zamierzał bowiem handlować $z$ rewolucyjną Francją. O wiele bliższy był mu pomysł zorganizowania wielkiej monarchistycznej krucjaty w celu ratowania tronu Ludwika XVI. Już 3 września 1790 r. Gustaw III pisał do Everta Taubego, że Hans Axel von Fersen nakreślił mu bardzo ponury obraz sytuacji we Francji. W związku $z$ tym król pozwolił sobie na następująca konstatację: „Wydaje mi się, że bałagan doszedł tam do szczytu i należałoby zorganizować taką ligę, jaką

30 Por. Z. Anusik, Dyplomacja..., s. 264-270; ide m, France..., s. 233-238.

${ }^{31}$ Por. R.N. Bain, op. cit., vol. II, s. 101-102; N. Åke s o n, op. cit., Bd I, s. 24; O. Jägerskiöld, op. cit., s. 335; Z. Anusik, Dyplomacja..., s. 286-287; idem, France..., s. 249-255. 
zorganizowali Grecy przeciwko Troi, dla przywrócenia porządku i pomszczenia honoru głów koronowanych. Bardzo chciałbym być Agamemnonem tej armii”. Marzenia o objęciu naczelnego dowództwa nad wojskami, których zadaniem byłoby przywrócenie starego porządku we Francji, towarzyszyć miały Gustawowi III do końca jego życia. Na razie jednak musiał odłożyć je na później. Tymczasem w październiku 1790 r. Zgromadzenie Narodowe oficjalnie wprowadziło trójkolorową banderę dla statków i okrętów francuskich. W styczniu 1791 r. francuski chargé d'affaires w Sztokholmie kawaler Jean de Gaussen wręczył Ulricowi Gustafowi Francowi oficjalna notę $z$ zawiadomieniem o zmianie flagi państwowej. Gustaw III nie tylko nie przyjał tego do wiadomości, ale zaproponował nawet w Petersburgu i w Kopenhadze, aby Rosja, Szwecja i Dania nie respektowały na Bałtyku tej zmiany. Propozycja ta została dobrze przyjęta przez oba dwory, które również nie zamierzały przyjmować w swoich portach statków francuskich $z$ trójkolorowa banderą na maszcie. Coraz większa uwage króla przyciagały też poczynania dworu madryckiego, który został przez niego uznany za potencjalnego sojusznika w walce przeciwko rewolucyjnej Francji. $Z$ dużym zadowoleniem przyjął Gustaw III również wiadomość, że także Hiszpania odmówiła uznania trójkolorowej bandery i zamknęła swoje porty przed statkami francuskimi. Na dwór hiszpański liczyli także francuscy emigranci, którzy usiłowali zainteresować madryckich polityków swoimi planami dotyczaccymi przyszłej inwazji na Francję. Osobista wizyta, jaka Karol hrabia d’Artois złożył w Madrycie w lutym 1791 r., nie przyniosła jednak żadnych rezultatów. Dwór hiszpański postanowił bowiem poczekać na dalszy rozwój wypadków na arenie międzynarodowej ${ }^{32}$.

Warto jednak pamiętać o tym, że po zawarciu pokoju z Rosja Gustaw III miał bardzo ograniczone możliwości podjęcia jakichkolwiek działań przeciwko rewolucyjnej Francji. Wycofanie się Szwecji $z$ wojny przeciwko Katarzynie II doprowadziło bowiem do zerwania współpracy $z$ państwami trójprzymierza. Doprowadziło też do zawieszenia rozmów o zawarcie sojuszu $z$ Rzecząpospolitą oraz do ochłodzenia stosunków z Turcją. W rezultacie Szwecja znalazła się

${ }^{32}$ Por. Noty J. de Gaussena adresowane do C.W. v. Dübena, Sztokholm 20 i 24 IX 1790, RA, Gallica vol. 533; Gustaw III do E. Taubego, 3 IX 1790, RA, Stafsundsarkivet, Evert Taubes Samling. vol. I; C.G. Ehrensvärd do Gustawa III, Madryt 14 II 1791, RA, Hispanica vol. 33. Por też N. Åk e s o n, op. cit, Bd I, s. 101; Z. Anu sik, Dyplomacja..., s. 294-295; idem, France..., s. 262-263. 
w kompletnej izolacji na arenie międzynarodowej. Nie zraziło to jednak bynajmniej Gustawa III do podejmowania nowych inicjatyw politycznych. W październiku $1790 \mathrm{r}$. rozpoczał on starania o uzyskanie korony polskiej w przypadku, gdyby nie przyją jej desygnowany przez Sejm Wielki na następcę Stanisława Augusta elektor saski Fryderyk August III. $Z$ tego też powodu władca Szwecji nie zdecydował się na ratyfikacje podpisanego w dniu 7 listopada $1790 \mathrm{r}$. w Warszawie polsko-szwedzkiego traktatu sojuszniczego. Król potrzebował bowiem pieniędzy na spłacenie powojennych długów i realizację kolejnych, rozległych zamierzeń politycznych. Szanse na urzeczywistnienie tych planów rysowały się ewentualnie po zdobyciu korony polskiej, nie obiecywał ich natomiast wcale traktat sojuszniczy wynegocjowany w Warszawie. W końcu listopada 1790 r. Gustaw III rozpoczął też pertraktacje $z$ szykującymi się do wojny $z$ Rosją państwami trójprzymierza. W tym samym czasie prowadził jednak również rozmowy $z$ dworem petersburskim. W początkach $1791 \mathrm{r}$. przedstawił $z$ kolei w Petersburgu i w Kopenhadze projekt utworzenia sojuszu trzech państw północnych. Zapewne liczył na to, że oba dwory popra jego zabiegi o koronę polską. Nie można jednak wykluczyć tego, że już wówczas widział w Danii i Rosji swoich przyszłych sojuszników w wojnie przeciwko rewolucyjnej Francji. Ponieważ jednak na razie projekty te nie przyniosły żadnych rezultatów, w lutym $1791 \mathrm{r}$. Gustaw III ponownie podją rozmowy $z$ dworami berlińskim i londyńskim. Cały czas negocjował również z Katarzyną II. Z rozmów tych Szwedzi starali się wyciągnąć jak największe korzyści, a obie strony szykujące się do wielkiego konfliktu zbrojnego nie szczędziły dworowi sztokholmskiemu daleko idacych obietnic. Przekonany o swoich ogromnych możliwościach, w marcu 1791 r. Gustaw III doprowadził do zerwania rozmów o zawarcie traktatu sojuszniczego z Rzecząpospolita. Podbijając zaś ciagle swoja cenę w negocjacjach $z$ państwami trójprzymierza i $z$ dworem petersburskim, doczekał chwili, kiedy opozycja parlamentarna w Anglii sparaliżowała planowana wyprawę floty na Bałtyk, co z kolei zmusiło do odwrotu także Prusy. Już w końcu kwietnia 1791 r. było prawie pewne, że do wybuchu spodziewanego konfliktu nie dojdzie. Nie wydaje się jednak, żeby Gustaw III zmartwił się zbytnio takim rozwojem wydarzeń. Spokój na Wschodzie umożliwiał mu bowiem skoncentrowanie całej uwagi na wypadkach zachodzacych we Francji ${ }^{33}$.

${ }^{33}$ Por. Z. Anusik, Misja polska $w$ Sztokholmie $w$ latach 1789-1795, Łódź 1993, s. 102-103, 117-118; id e m, Rokowania o polsko-szwedzki traktat sojusz- 
Niemal w tym samym czasie rozpoczął rozmowy z przywódcami francuskiej emigracji. Niepowodzenie lutowej wyprawy do Madrytu skłoniło hrabiego d'Artois do nawiązania bliższego kontaktu $z$ dworem sztokholmskim. Dnia 8 kwietnia 1791 r. napisał on $z$ Parmy list do Gustawa III, w którym prosił króla Szwecji o wsparcie w Stambule jego zabiegów o uzyskanie kilku milionów liwrów tureckiego subsydium. Zdaniem hrabiego najlepszym pośrednikiem $\mathrm{w}$ tych rokowaniach mógłby być baron Georg Joseph von Brentano, znany ze swoich licznych talentów i gorliwości. Odwołując się do Gustawa III jako do dawnego sojusznika Francji i gwaranta traktatu westfalskiego, hrabia nie omieszkał zaznaczyć, że wszystkie jego poczynania podejmowane sa w interesie Ludwika XVI. Wypada jednak wątpić, by król szwedzki, informowany z Paryża przez Hansa Axela von Fersena i Erika Magnusa Staëla von Holsteina o prawdziwym nastawieniu pary królewskiej do działań podejmowanych przez emigrantów, mógł uwierzyć w to ostatnie zapewnienie. Niemniej jednak należy przypuszczać, że nie odmówił on wsparcia wnukowi Ludwika XV. W tym samym czasie władca Szwecji podjał bowiem kilka decyzji, które świadczyły jednoznacznie o jego wrogim nastawieniu wobec rewolucyjnej Francji. Dnia 8 kwietnia 1791 r. Gustaw III napisał do swojego posła przy sejmie Rzeszy w Ratyzbonie, barona Carla Gustafa Oxenstierny, rozkazujac mu popierać żądania książąt niemieckich mających posiadłości w Alzacji i Lotaryngii. Książęta ci czuli się pokrzywdzeni dekretami Zgromadzenia Narodowego (Konstytuanty) z 4 sierpnia 1789 r., które znosiły ich sąy oraz służebności osobiste ciążące na ich chłopach. Co prawda, Konstytuanta proponowała im odszkodowanie, ale propozycja ta została przez nich odrzucona. W grudniu 1790 r., po spacyfikowaniu zbuntowanej Belgii, cesarz Leopold II, powołu-

niczy w 1790 roku, „Zapiski Historyczne” 1996, t. LXI, z. 2-3, s. 37-38; idem, O szwedzki alians. Karta z dziejów stosunków politycznych pomiędzy Sztokholmem a Warszawa $w$ dobie Sejmu Czteroletniego, „Acta Universitatis Lodziensis”, Folia Historica 57, 1996, s. 100-101; i d e m, O polska koronę. Dwór sztokholmski wobec kwestii sukcesji tronu $w$ Polsce $w$ dobie Sejmu Czteroletniego, [w:] Studia i materiały $z$ dziejów nowożytnych, red. K. Matwijowski, S. Ochmann-Staniszewska, Prace historyczne XIII, Wrocław 1995, s. 147-167; idem, Szwedzki rywal Fryderyka Augusta. Gustaw III wobec projektów sukcesji tronu $w$ Polsce $w$ latach 1790-1792, „Rocznik Łódzki” 1997, t. XLIV, s. 89-115; ide m, Czy dwór berliński proponowat Szwecji udział $w$ drugim rozbiorze Polski? Przyczynek do dziejów stosunków politycznych pomiędzy Sztokholmem, Berlinem $i$ Warszawa $w$ latach 1789-1792, [w:] Oświeceni wobec rozbiorów Polski, red. J. Grobis, Łódź 1998, s. 43-63; id e m, Dyplomacja..., s. 288-294; id e m, France..., s. 257-262. 
jąc się na traktat westfalski, wystosował więc do ministra spraw zagranicznych Francji Armanda Marca de Montmorina urzędową notę, protestując przeciwko zastosowaniu wobec książąt niemieckich przepisów prawa francuskiego. Sprawa ta stanowiła dogodny pretekst do obcej interwencji we Francji i dlatego też została tak skwapliwie podchwycona przez dwór sztokholmski. $Z$ tego samego powodu Gustaw III próbował nawiązać bliższy kontakt $z$ dworem wiedeńskim. Jeszcze w początkach kwietnia 1791 r. Georg Gustaf Wrangel, poseł szwedzki w Italii, rezydujący na co dzień w Genui, spotkał się $\mathrm{w}$ tym mieście $z$ cesarzem Leopoldem II i przeprowadził $z$ nim długa rozmowę na temat aktualnej sytuacji we Francji. Ponieważ jednak $z$ rozmowy tej wynikało, że Austria nie zamierza na razie ani mieszać się do spraw francuskich, ani też zacieśniać swoich związków ze Szwecją, Gustaw III zmuszony został do dokonania zwrotu w stronę dworu petersburskiego. O takim rozwiąaniu myślał zreszta od dawna. Pozyskanie przychylności i poparcia ze strony Katarzyny II stawało się natomiast niezbędne od momentu, kiedy do Sztokholmu dotarły informacje o uchwaleniu przez sejm warszawski Konstytucji 3 maja. Tylko ewentualna pomoc cesarzowej prolongować mogła jego nadzieje na polska koronę lub jakieś nabytki terytorialne. Tylko współdziałanie $z$ Rosja przynieść mogło wreszcie powodzenie jego rozległych planów politycznych skierowanych przeciwko rewolucyjnej Francji ${ }^{34}$.

Tymczasem w lutym 1791 r. Hans Axel von Fersen rozpoczą działania zmierzające do zorganizowania ucieczki rodziny królewskiej z Paryża. Jego poczynania były bardzo uważnie śledzone przez dwór sztokholmski. Od początku kwietnia 1791 r. Gustaw III był

${ }^{34}$ Por. Karol hrabia d'Artois do Gustawa III, Parma 8 IV 1791 (kopia), RA, Gallica vol. 521. Por. też N. Åke s o n, op. cit., Bd I, s. 37-38, 63, 76-77; A. Mathiez, La révolution française, t. I (La chute de la royauté), Paris 1928, s. 161; id e m, Rewolucja francuska, Warszawa 1956, s. 148. Warto również w tym miejscu zwrócić uwage na to, że wiadomość o uchwaleniu Konstytucji 3 maja i zaproszeniu na tron polski elektora saskiego wywołała wściekłość króla szwedzkiego. W liście pisanym ok. 18 V 1791 r. stwierdził on bowiem $z$ irytacją: „Tron polski się wściekł! Polacy za to zapłaca, a my się podzielimy”. Por. Gustaw III do G.M. Armfelta, Sztokholm ok. 18 V 1791, Bref till Armfelt, s. 177. Zawiedziony w swoich nadziejach na zdobycie polskiej korony, wracał więc Gustaw III do starych projektów związanych z możliwością dokonania rozbioru Rzeczypospolitej. Rzecz bardzo charakterystyczna, że powrót do tych planów zbiega się dokładnie w czasie z przyjazdem do Sztokholmu nowego ambasadora rosyjskiego, Ottona Magnusa von Stackelberga. Por. Z. Anusik, O polska..., s. 160; idem, Misja..., s. 118; idem, Szwedzki..., s. 109; id e m, Dyplomacja..., s. 295-296; ide m, France..., s. 263-264. 
zresztą na bieżąco informowany o wszystkich ruchach paryskich spiskowców. Informując króla o swoich przedsięwzięciach, Hans Axel von Fersen liczył na to, że jego władca doprowadzi do neutralizacji państw trójprzymierza i zapobiegnie ich wrogim wystąpieniom przeciwko dworowi francuskiemu. Hrabia nie przewidział jednak tego, że Gustaw III zechce osobiście i bezpośrednio zaangażować się w akcję przywracania dawnego porządku we Francji. Nie powinno to jednak stanowić dla Fersena żadnego zaskoczenia. Właśnie $z$ myślą o przyszłej interwencji na rzecz Ludwika XVI Gustaw III już od kilku miesięcy prowadził bowiem rokowania $z$ dworem petersburskim, o czym niewatpliwie informował swojego korespondenta w Paryżu. Ponieważ jednak rozmowy prowadzone w Petersburgu długo nie przynosiły oczekiwanych rezultatów, król szwedzki z coraz większą niecierpliwością oczekiwał na przyjazd do Sztokholmu nowego ambasadora Katarzyny II. Z ogromnym napięciem śledził także wszystkie poczynania hrabiego Fersena w Paryżu. Dnia 10 maja 1791 r. pisał do swojego posła w Petersburgu Curta von Stedingka, że otrzymał ze stolicy Francji wiadomość, że kurier ambasady rosyjskiej, który wyjechał z Paryża 1 kwietnia, zabrał ze soba pakiet korespondencji Hansa Axela von Fersena przeznaczonej dla dworu sztokholmskiego. Ponieważ Stedingk nie uczynił o tym żadnej wzmianki w swoich ostatnich depeszach, król zorientował się, że nie dostał on jeszcze tej przesyłki. Był tym bardzo zaniepokojony i obawiał się, że pakiet został przejęty na terenie Francji, co mogło mieć fatalne następstwa dla francuskiej rodziny królewskiej. W dalszej części tego listu Gustaw III pisał, że wydarzenia z 18 i 19 kwietnia (doszło wówczas do zamieszek przed pałacem tuileryjskim) wystawiły Ludwika XVI na tak oczywiste niebezpieczeństwo, że on sam w jeszcze większym stopniu postanowił zainteresować się jego losem. Rozkazał też Stedingkowi, aby zorientował się, co stało się $z$ feralna przesyłka $z$ Paryża i natychmiast powiadomił go o wynikach swojego dochodzenia. Zakończył zaś stwierdzeniem, że niezmiennym celem jego polityki jest dążenie do jak najszybszego sfinalizowania rokowań z Katarzyną II $^{35}$.

W przeddzień przyjazdu do Sztokholmu Ottona Magnusa von Stackelberga, 17 maja 1791 r. Gustaw III napisał obszerny list do

35 Por. H.A. Barton, Count Hans Axel von Fersen. Aristocrat in an Age of Revolution, Boston 1975, s. 110; Gustaw III do C. v. Stedingka, pałacyk Haga 10 V 1791, RA, Muscovitica vol. 489. Por. też N. Åke s o n, op. cit., Bd I, s. 41; Z. A nu sik, Dyplomacja..., s. 337; ide m, France..., s. 301-302. 
przebywającego w Szwajcarii głównego doradcy francuskiej pary królewskiej i animatora jej sekretnej polityki Louisa Auguste'a Le Tonnelier barona de Breteuil. Rozpoczą od stwierdzenia, że od początku z zainteresowaniem śledził wszystko to, co działo się we Francji. Nieszczęścia tego kraju i rodziny królewskiej przepełniały go bólem i rozpacza. Nigdy jednak nie zapomniał o obowiązkach wynikających $z$ dawnej przyjaźni i przywiązania do rodziny Ludwika XV. Otoczony przez wrogów, walcząc $z$ przeważającymi siłami Cesarstwa Rosyjskiego i $z$ odradzająca się hydra anarchii i swawoli we własnym kraju, $z$ niepokojem obserwował wydarzenia, które pogrążyły Francję w chaosie, w jakim znajduje się nadal, wstrząsnęły tronem i zniszczyły porządek oraz prawo. Wiele razy okazywał też zainteresowanie dla losu francuskiej rodziny królewskiej. Dopóki jednak prowadził wojnę, nie mógł poświęcić sprawom Francji dostatecznie dużo uwagi. Od czasu zawarcia pokoju nie stracił jednak nawet jednej chwili, od razu przystępując do obmyślania środków potrzebnych do przyjścia $z$ pomoca swojemu dawnemu sojusznikowi i wnukowi Ludwika XV. W sytuacji, gdy mocarstwa związane więzami krwi z Domem Francji wydaja się porzucać jego sprawę, uważa za swój święty obowiązek jego wspomożenie. Przez Fersena powiadomił rodzinę królewską o swoich zamiarach. Od niego dowiedział się też, że Breteuil został upoważniony do prowadzenia wszystkich negocjacji $z$ obcymi mocarstwami. Śpieszy więc przedstawić mu swoje plany i poglądy, wysyłając $z$ listem hrabiego Nilsa Antona Barcka, zatrudnionego w resorcie spraw zagranicznych, syna byłego ministra szwedzkiego w Wiedniu. Dalej Gustaw III pisał, że zna bardzo dobrze roztropność, wierność i gorliwość swojego wysłannika i dlatego wybrał go do misji tak ważnej i tak delikatnej. Przekonywał też Breteuila, że powinien on powierzyć Barckowi wszystko to, o czym obawia się pisać bezpośrednio do niego samego. Przechodzac zaś do meritum sprawy, władca Szwecji zaoferował królowi Francji 6 tys. zaprawionych w boju żołnierzy szwedzkich i sześć okrętów liniowych - siły te miały dopomóc mu $\mathrm{w}$ dziele przywracania dawnego porządku. Obiecywał także udział w przyszłej ekspedycji przynajmniej 3 tys. żołnierzy rosyjskich, jeśli tylko uda mu się przezwyciężyć przeszkody na drodze do zawarcia traktatu sojuszniczego z Katarzyną II. W zamian za przysłanie zbrojnej pomocy zażądał od dworu francuskiego zapewnienia pieniędzy niezbędnych do utrzymania i transportu oddziałów, nieograniczonej komendy w sytuacji, gdy osobiście 
znajdzie się na polu walki, i formalnego zapewnienia, że zostana odnowione dawne alianse szwedzko-francuskie, jak tylko dojdzie do restauracji dawnych praw króla Francji. Konkretnie chodziło mu o odnowienie traktatu z 19 lipca 1784 r. oraz tajnej konwencji subsydiowej z 1 czerwca 1784 r. Wysokość rocznych subsydiów miała jednak zostać powiększona do sumy nie mniejszej niż $3 \mathrm{mln}$ liwrów. Gustaw III zapewniał przy tej okazji barona, że wie o tym, że zdobycie pieniędzy może być w obecnej sytuacji bardzo trudne dla króla Francji. Sam gotów byłby przyjść mu $z$ pomoca bez żadnych warunków wstępnych, ale ograniczone zasoby finansowe zmuszaja go do ich postawienia. Jeśli jednak w przyszłości Hiszpania zainteresuje się nieszczęściem Francji i jeśli zechce przyjść jej z pomocą, może dostarczyć żądanych pieniędzy i usunąć jedyną przeszkodę, która uniemożliwia królowi Szwecji natychmiastowe udzielenie pomocy jego francuskiemu kuzynowi. Dalej Gustaw III pisał, że nie wydaje mu się ani użyteczne, ani korzystne dla interesów Francji, aby Hiszpanie wysłali swoją armię na pomoc Ludwikowi XVI. Pojawienie się w granicach Francji wojsk hiszpańskich może bowiem doprowadzić do odnowienia się dawnych animozji między oboma narodami i utrudnić dzieło ratowania rodziny królewskiej. Zupełnie inaczej wygląda sprawa oddziałów szwedzkich. Francuzi nie maja bowiem nic przeciwko Szwedom. Długotrwały sojusz i wspólnie odnoszone zwycięstwa czynia $z$ nich prawie naturalizowanych Francuzów. Ponadto Szwecja nie ma żadnych ukrytych zamiarów wobec Francji. Jedynym jej celem jest bowiem restauracja monarchii. Ludwik XVI nie musi się obawiać sukcesów wojsk szwedzkich, tak jak musiałby się obawiać sukcesów swoich zbyt potężnych i interesownych sąsiadów. Swoje wywody zakończył król stwierdzeniem, że jeśli jego propozycje zostana przyjęte i Breteuil otrzyma zgodę któregoś $z$ mocarstw na dysponowanie jakimś portem w pobliżu granic Francji, to on sam chciałby o tym wiedzieć, aby wysadzić tam na ląd swoje oddziały, ustanowić tam swoją główną kwaterę i zaopatrywać od strony morza swoją armię. W tym samym liście Gustaw III poinformował Breteuila o swoim zamiarze wyjazdu do Akwizgranu, gdyż stan jego zdrowia wymagać miał natychmiastowego udania się do wód. Zapowiadał jednak, że stamtąd będzie śledził dalszy rozwój wypadków we Francji i będzie prowadził negocjacje $z$ niemieckimi książętami, których prawa zostały naruszone przez uchwały buntowniczego Zgromadzenia. Informując barona, że nie czekając na jego odpowiedź, 
natychmiast podejmie niezbędne przygotowania do projektowanej ekspedycji, Gustaw III wyraził też przekonanie, że Ludwik XVI nie powinien wchodzić w żadne układy ze swoimi poddanymi. Odzyskawszy wolność, powinien prowadzić wojnę $z$ buntownikami aż do chwili, kiedy zostana mu przywrócone wszystkie prawa, kiedy zaprowadzi porządek wewnattrz kraju i kiedy zapewni sobie silną pozycję na zewnątrz, niezbędną zarówno dla pożytku władców, którzy zechca przyjść mu z pomoca, jak i dla utrzymania równowagi sił w Europie ${ }^{36}$.

Doczekawszy się wreszcie przyjazdu Stackelberga, Gustaw III nie zamierzał jednak osobiście prowadzić skomplikowanych rokowań $z$ wysłannikiem Katarzyny II. Informowany przez Fersena o znacznym zaawansowaniu przygotowań do wyjazdu rodziny królewskiej z Paryża, władca Szwecji już wcześniej podjął bowiem decyzję o podróży do Akwizgranu, gdzie postanowił oczekiwać na „uwolnienie” Ludwika XVI z rak francuskich buntowników. Wybór Akwizgranu na główna kwaterę Gustawa III nie był bynajmniej przypadkowy. Miasto to od początku emigracji stało się siedzibą dużej grupy arystokratycznych uchodźców z Francji. Przebywał tu książę Louis François de Conti (pod przybranym nazwiskiem hrabiego de Neuteuil), hrabia Joseph Hyacinthe de Vaudreuil, książę André Hercule de Fleury ( $z$ małżonka), hrabia Auguste Gabriel de Coigny i wielu innych. Co prawda, wiosna 1791 r. większość wspomnianych arystokratów (w tym książę de Conti) przebywała w innych miastach europejskich, ale w Akwizgranie pozostała księżna de Croy $z$ rodziną oraz (by posłużyć się sformułowaniem samego Gustawa III) „wszyscy znakomici wygnańcy $z$ dworu francuskiego, tworzacy najlepszą $z$ możliwych kompanię, tak w odniesieniu do mężczyzn, jak i do kobiet". Całe to dostojne i wyrafinowane towarzystwo, stanowiąc doskonały pretekst do pojawienia się władcy Szwecji w Akwizgranie, miało też umilić mu czas oczekiwania na ostateczne rozstrzygnięcia, jakie wkrótce zapaść miały w Paryżu. Od chwili opuszczenia Sztokholmu król pozostawał również w stałym kontakcie ze swoimi zaufanymi współpracownikami - Gustafem Mauritzem Armfeltem oraz Ulricem Gustafem Francem,

${ }^{36}$ Por. Gustaw III do L.A. de Breteuila, pałacyk Haga 17 V 1791 (kopia), RA, Kungl. arkiv I. Handskriftsamlingen: Gustaf III. Ten sam list por. Gustave III par ses lettres, ed. par G. v. Proschwitz, Göteborg-Paris 1986, s. 340-343. Por. także N. Åke s o n, op. cit., Bd I, s. 31, 42-43; H.A. Barto n, Scandinavia..., s. 193; Z. Anusik, Dyplomacja..., s. 338-339; id em, France..., s. 302-304. 
którym powierzył zadanie sfinalizowania rozmów $z$ ambasadorem Rosji. Szykując się do działań na granicy francuskiej, Gustaw III niecierpliwił się brakiem zadowalających postępów w rokowaniach sztokholmskich. Aby przyśpieszyć te negocjacje, gotów był pójść na pewne ustępstwa wobec dworu petersburskiego. Zamierzał np. zrezygnować $z$ konsekwentnie wysuwanego dotąd żądania skorygowania linii granicznej z Rosja. Upierał się jednak przy subsydiach, które miały mu umożliwić odbudowanie dawnego autorytetu władzy królewskiej we Francji. W poszukiwaniu ewentualnych sojuszników przeciwko rewolucji francuskiej władca Szwecji nie brał początkowo pod uwagę ani emigrantów, ani cesarza. Uważał, że nastawiona wówczas na kierunek antyangielski polityka Leopolda II uniemożliwi mu skuteczną interwencję w obronie interesów jego siostry i szwagra. W czasie pobytu w Brunszwiku Gustaw III prowadził również rozmowy $z$ reprezentujacym interesy dworu pruskiego księciem Karolem Wilhelmem Ferdynandem Brunszwickim. Otrzymał od niego zapewnienie o gotowości państw trójprzymierza do zawarcia korzystnego dla Szwecji traktatu sojuszniczego. I chociaż król szwedzki nie był już w zasadzie zainteresowany podtrzymywaniem rozmów $z$ dworami berlińskim i londyńskim, to jednak złożył obietnicę, że odłoży na kilkanaście dni ostateczna decyzje w sprawie sfinalizowania sztokholmskich rozmów z Rosją. Gustaw III postanowił bowiem potraktować propozycje księcia Brunszwickiego jako zabezpieczenie, na wypadek gdyby negocjacje sztokholmskie nie doprowadziły do podpisania układu sojuszniczego $z$ dworem petersburskim. Piszac c list do Armfelta w dniu 8 czerwca 1791 r., Gustaw III nie mógł jeszcze wiedzieć o tym, że w Sztokholmie podpisano już wstępne porozumienie ze Stackelbergiem. Dnia 24 maja negocjatorzy ze strony szwedzkiej, hrabia Carl Axel Wachtmeister, Gustaf Mauritz Armfelt, Ulric Gustaf Franc i Anders Håkansson, złożyli bowiem swoje podpisy na akcie traktatu $z$ dworem petersburskim. W tym samym dniu podpisali również tajną konwencję dotyczacą współdziałania obu dworów przeciwko Prusom i Anglii. Gustaf Mauritz Armfelt parafował natomiast tajny protokół w sprawie przyszłego współdziałania Szwecji i Rosji przeciwko rewolucyjnej Francji. Na mocy tego porozumienia Katarzyna II miała wypłacić dworowi sztokholmskiemu subsydia w wysokości 2,04 mln riksdalerów za pierwsze sześć miesięcy wojny oraz dodatkowo 169 tys. riksdalerów z przeznaczeniem do prywatnej szkatuły Gustawa III. Informacje o tych dokonaniach 
sztokholmskich negocjatorów Armfelt przekazał jednak królowi dopiero w liście z 31 maja 1791 r. Ostrzegał swojego dostojnego korespondenta, że sprawa nie jest całkowicie zakończona. Wszystkie podpisane w Sztokholmie dokumenty musiały bowiem zostać ratyfikowane przez cesarzowa, a $z$ tym mogły być dość poważne trudności ${ }^{37}$.

Dnia 9 czerwca 1791 r. Erik Magnus Staël von Holstein, który nie został wtajemniczony w plany Gustawa III, pisał do króla o nasilaniu się w Paryżu pogłosek o spodziewanym ataku obcych wojsk na Francję. Jego zdaniem pogłoski te były podsycane przez arystokratów, którzy chcieli w ten sposób zastraszyć swoich wrogów i zachęcić do działania własnych stronników. Odnosząc się zaś do licznych spekulacji na temat zagranicznej podróży króla szwedzkiego, ambasador odnotował, że mówi się nawet o tym, że zamierza on przyjechać na kilka dni incognito do Paryża. O wiele bardziej interesująca dla Gustawa III była jednak treść listu, który tego samego dnia napisał w Solurze baron de Breteuil. Ten bowiem obiecywał mu ogromne korzyści po odzyskaniu wolności przez Ludwika XVI. Baron pisał jednak także, że na razie, dopóki król jest w rękach buntowników, należy postępować bardzo ostrożnie i nie obnosić się jawnie z przyjaźnią szwedzko-francuską, żeby

37 Por.Z.A nu sik, Opolska..., s. 160-161; ide m, Szwedzki..., s. 110; id e m, Dyplomacja..., s. 340-341; id e m, France..., s. 304-305; A. Söd er hjelm, Sverige..., s. 229-230; e a d e m, Revolutionärer och emigranter, Stockholm 1918, s. 81, 86 n. W kwestii instrukcji Gustawa III dotyczących przebiegu rokowań ze Stackelbergiem por. Gustaw III do G.M. Armfelta, Rostok 2 VI 1791, Bref till Armfelt, s. 177-179. Por. też N. Åkeson, op. cit., Bd I, s. 40-41, 45-48; C.T. Odhner, Gustaf III och Katarina II efter freden $i$ Värälä, Stockholm 1895, s. 21-29 (tu szczegółowe omówienie negocjacji szwedzko-rosyjskich od II do V 1791 r.); oraz Gustaw III do G.M. Armfelta, Brunszwik 8 VI 1791, Bref till Armfelt, s. 179-181. Problemy $z$ finalizacja rozmów o podpisanie traktatu sojuszniczego $z$ Rosja przewidywał w tym samym czasie również C. v. Stedingk, który pisał do Gustawa III o trudnych rozmowach, jakie dwór petersburski prowadzi $z$ wysłannikami Londynu i Berlina. Por. C. v. Stedingk do Gustawa III, Petersburg 16/27 V 1791, apostille, RA, Muscovitica vol. 451. Także szwedzki sekretarz stanu dość sceptycznie odnosił się do perspektywy ratyfikacji przez cesarzowa wynegocjowanych w Sztokholmie porozumień. Por. U.G. Franc do C. v. Stedingka, Sztokholm 27 V 1791, RA, Muscovitica vol. 489. Dodajmy też w tym miejscu, że w tym samym czasie Curt v. Stedingk otrzymał nominacje na ambasadora Szwecji na dworze petersburskim. Por. A. Forsse11, Histoire de l'administration des affaires étrangères 1721-1809, [w:] Histoire de l'Administration des Affaires Étrangères de Suède, Upsal 1940, s. 362. Co prawda, Forssell nie podaje dokładnej daty nominacji Stedingka na stanowisko ambasadora, ale należy przypuszczać, że nastąpiła ona wkrótce po przyjeździe do Sztokholmu Ottona von Stackelberga. 
nie ściagnąć na niego jakiegoś niebezpieczeństwa. Ludwik XVI znajduje się bowiem w takim położeniu, że musi zachowywać pozory i postępować $z$ najwyższą delikatnością, unikając wszelkich spięć i zadrażnień. Breteuil przekonywał też Gustawa III, że jednym $z$ powodów, dla których jego król znosi cierpliwie krzywdy i prześladowania, jest brak pieniędzy. Wszystko wskazuje jednak na to, że już wkrótce stanie on na czele armii i wraz $z$ nią upomni się o swoje prawa. Zdaniem Breteuila Ludwik XVI miał być przekonany o tym, że przyszły sukces zostanie osiągnięty dzięki poparciu narodu, a nie dzięki pomocy pochodzącej $z$ zagranicy. $\mathrm{W}$ tej kwestii baron w pełni zgadzał się $z$ poglądami swojego władcy. Uprzejmie podziękował więc za ofertę zbrojnej pomocy, będąc przekonanym, że do realizacji jego planów wystarczą umiejętności francuskich generałów i żołnierzy. Uskarżając się na zbyt dużą odległość Szwecji od Francji, z żalem skonstatował, że w tych okolicznościach, przynajmniej na razie, Ludwik XVI nie będzie prosił Gustawa III o wywiązanie się z jego sojuszniczych zobowiązań. Jednak natychmiast po tym, jak tylko król odzyska wolność, baron nie omieszka przekazać wiadomości o miejscu dogodnym do założenia obozu wojskowego. Dwór francuski wyznaczy też odpowiedni port do lądowania oddziałów szwedzkich. Według Breteuila wszystkie warunki, które przedstawił Gustaw III, sa tak oczywiste i sprawiedliwe, że król z pewnościa je zaakceptuje, a następnie skrupulatnie i $z$ wielka przyjemnością wypełni. Do pryncypiów jego systemu politycznego należy bowiem podtrzymanie sojuszu $z$ dworem sztokholmskim. Jednocześnie baron ostrzegał króla szwedzkiego przed Francuzami, których mógłby spotkać w Spa i w Akwizgranie. Radził zachować wobec nich dużą ostrożność i nie deklarować się otwarcie $z$ przyjaźnią dla króla Francji. Zgromadzenie Narodowe (Konstytuanta) miało mieć bowiem wśród emigrantów wielu szpiegów, którzy skrupulatnie wykorzystywali wszelkie niedyskrecje i brak ostrożności swoich rozmówców. Gdyby szpiedzy ci donieśli o tym, co robi i mówi w Spa król Szwecji, mogłoby to spowodować zwiększenie dozoru nad osobą Ludwika XVI. Breteuil pisał też, że dobra znajomość zarówno książąt niemieckich, jak i ludzi, którzy kieruja ich sprawami, skłania do przypuszczeń, że Gustaw III napotka na ogromne trudności w realizacji swoich wielkich planów. Swój list baron zakończył licznymi pochwałami pod adresem młodego Barcka, który odziedziczyć miał wszystkie cnoty swojego sławnego ojca. Dziękując za podpowiedzi Gustawa III w sprawach, których prowa- 
dzenie powierzył mu jego władca, Breteuil prosił króla szwedzkiego, aby zechciał uwierzyć, że jego król nigdy nie myślał poważnie o tym, aby pertraktować $z$ własnymi poddanymi w kwestii swoich monarszych uprawnień. Na Ludwika XVI rzuca się wiele kalumni, o czym sam Gustaw III będzie miał okazję przekonać się w Spa. Wiele razy król Francji czuł się urażony niesprawiedliwymi plotkami rozsiewanymi na temat jego postępowania, ale znosił to cierpliwie, będac przekonany o tym, że jego końcowy sukces zamknie usta wszystkim potwarcom ${ }^{38}$.

Wydaje się, że odpowiedź Breteuila w pełni zadowoliła Gustawa III. Co prawda, baron dość jednoznacznie odrzucił propozycje zbrojnej interwencji wojsk szwedzkich we Francji, ale nie wykluczał współdziałania $z$ dworem sztokholmskim w chwili, gdy Ludwik XVI odzyska możliwość dysponowania własna osobą. List barona otwierał więc droge do dalszych negocjacji, na czym w gruncie rzeczy najbardziej zależało szwedzkiemu królowi. Było bowiem dla niego sprawą zupełnie oczywista, że przed sfinalizowaniem rokowań z Katarzyną II nie będzie w stanie podjąc żadnych działań przeciwko rewolucyjnej Francji. Sązić można, że list Breteuila dotarł już do rąk króla, gdy rankiem 14 czerwca 1791 r. wjeżdżał on do Akwizgranu. Tutaj też Gustaw III z niecierpliwością oczekiwać miał na rezultaty działań Fersena w Paryżu, spodziewając się w każdej chwili nadejścia wiadomości o pomyślnym przebiegu planowanej ucieczki francuskiej rodziny królewskiej. Nadal niepokoił się jednak brakiem postępów w rokowaniach $z$ dworem petersburskim i nalegał na jak najszybsze zakończenie tych negocjacji. Dnia 19 czerwca 1791 r. w liście do Gustafa Mauritza Armfelta i Ulrica Gustafa Franca zapowiadal, że gdy tylko otrzyma wieści potwierdzające bezpieczny wyjazd francuskiej rodziny królewskiej z Paryża, natychmiast wyśle do Sztokholmu swojego adiutanta $z$ nowymi rozkazami dotyczacymi sprawy podpisania negocjowanej konwencji $z$ Rosja. W tym samym liście król przekazywał również polecenie, żeby Armfelt zaraz po podpisaniu traktatu $z$ dworem petersburskim rozpoczą przygotowania do wysłania szwedzkich oddziałów wojskowych nad granicę francuską. Zbrojenia szwedzkie miały jednak zostać utrzymane w ścisłej tajemnicy, a koncentrację oddziałów miano przeprowadzić pod pretekstem zapewnienia bez-

38 Por. E.M. Staël v. Holstein do Gustawa III, Paryż 9 VI 1791, RA, Gallica vol. 476; L.A. de Breteuil do Gustawa III, Solura 9 VI 1791, RA, Gallica vol. 524; Z. Anusik, Dyplomacja..., s. 341-343. 
pieczeństwa granic państwa w obliczu możliwości wybuchu wojny między Rosja a państwami trójprzymierza. Dokładnie w tym samym czasie Erik Magnus Staël von Holstein zaczą podejrzewać, że jego władca zamierza odegrać jakąś rolę w rozwiązywaniu wewnętrznych problemów Francji. W depeszy pisanej 19 czerwca 1791 r. zapewniał bowiem Gustawa III o swojej lojalności i bezgranicznym oddaniu dla jego sprawy. Przyrzekał także posłuszeństwo dla wszystkich jego rozkazów. Potwierdzając otrzymanie polecenia, w myśl którego Gustaw III nakazywał odwołanie $z$ Francji wszystkich oficerów szwedzkich znajdujących się nadal w jej służbie, zastanawiał się tylko nad tym, jak powinien postapić w przypadku, gdyby od opuszczajaccych służbę oficerów zażądano przysięgi, że nie podejmą oni żadnych działań skierowanych przeciwko rewolucji. W tej samej depeszy znalazła się także informacja, że jeden z przywódców Zgromadzenia Narodowego, człowiek, który darzyć miał Gustawa III najwyższym szacunkiem, wspomniał o możliwości podpisania bardzo korzystnego dla Sztokholmu traktatu sojuszniczego. W innych okolicznościach Staël $z$ pewnością nie potraktowałby obojętnie takiego wynurzenia. Teraz jednak, wiedząc o zdecydowanej niechęci króla wobec porządków panujących we Francji, nie podtrzymał dyskusji i nie próbował nawet wchodzić w jakiekolwiek szczegóły dotyczace tej propozycji ${ }^{39}$.

W przeciwieństwie do ambasadora w Paryżu, który nie był informowany o polityce dworu sztokholmskiego wobec Francji, zamiary Gustawa III od dawna były znane jego posłowi przy dworze petersburskim. Dopiero 14 czerwca 1791 r. Curt von Stedingk wyraził jednak w pełniejszej formie swoją opinię na ich temat. Pisał bowiem wówczas, że w sprawie rokowań o podpisanie traktatu sojuszniczego $z$ Rosją wszystko będzie zależało od postawy państw trójprzymierza. Jeśli sprzymierzeni będą trzymać się dobrze i będa stanowić poważne zagrożenie dla dworu rosyjskiego, Katarzyna II będzie potrzebowała porozumienia $z$ Gustawem III i zaakceptuje przedstawione przez niego warunki. Jeśli jednak Londyn i Berlin wycofają się ze swojej dotychczasowej polityki, wówczas Rosjanie będą próbowali zawrzeć sojusz ze Szwecją za możliwie najniższa

${ }^{39}$ Por. Gustaw III do G.M. Armfelta, Akwizgran 16 VI 1791 oraz Gustaw III do G.M. Armfelta i U.G. Franca, Akwizgran 19 VI 1791, Bref till Armfelt, s. 182183 i 184-185; oraz A. Södrhjelm, Sverige..., s. 232; N. Åke s o n, op. cit., Bd I, s. 31-32, 49-50. Por. też E.M. Staël v. Holstein do Gustawa III, Paryż 19 VI 1791, RA, Gallica vol. 476; Z. Anusik, Dyplomacja..., s. 343-344; idem, France..., s. 307-308. 
cenę. Równie interesujące były uwagi Stedingka w odniesieniu do spraw francuskich. W tej samej depeszy poseł pisał bowiem, że na dworze petersburskim zaczęto poważnie watpić w to, czy król Szwecji naprawdę jest zdecydowany na odegranie aktywnej roli w rozwiąywaniu problemów Francji. Sam poseł zachowywał w tej sprawie całkowite milczenie, używając całej swojej zręczności dla zmylenia ciekawskich. Uważał bowiem, że musi zachować wielką ostrożność w sprawie, od której zależy ocalenie tak rodziny królewskiej, jak i całej Francji. Stedingk przekonywał Gustawa III, że aczkolwiek on sam życzyłby sobie pełnego triumfu kontrrewolucji we Francji, to jednak należy powstrzymać się od otwartych wystapień przeciwko nowym porządkom dopóty, dopóki rodzina królewska nie będzie całkowicie bezpieczna. Jego zdaniem również książęta powinni wstrzymać się na razie od wszelkich wrogich wobec rewolucji poczynań. Co ciekawe, podobnie jak nieco wcześniej Breteuil, Stedingk także prosił Gustawa III o zachowanie dużej ostrożności w Akwizgranie. Twierdził bowiem, że doskonale zna ludzi tam przebywających. Mają oni zwyczaj mówić, że w pobliżu granic Francji przebywa 50 tys. emigrantów i jeśli tylko ktoś powie, że jest ich zaledwie 10 tys., to uważaja go za zdeklarowanego demokratę. W ogóle Stedingk doszedł do wniosku, że nie nadszedł jeszcze czas na wybuch kontrrewolucji we Francji. Uważał, że najlepiej byłoby poczekać do końca kadencji Zgromadzenia Narodowego (Konstytuanty), które miało się rozwiązać jesienią. Niemniej jednak $z$ całego serca zachęcał swojego króla do interwencji we Francji w celu ratowania Ludwika XVI i jego rodziny. Był przekonany, że również cesarzowa zdecyduje się wreszcie na współdziałanie $z$ władca Szwecji i udzieli mu wsparcia w dziele ratowania francuskiej rodziny królewskiej ${ }^{40}$. I chociaż Stedingkowi nie udało się do końca przeniknać prawdziwych intencji dworu petersburskiego, jedno wydaje się pewne. W Akwizgranie, w Sztokholmie i w Petersburgu $z$ równa niecierpliwością oczekiwano wieści o powodzeniu ucieczki Ludwika XVI. Spokój panował tylko w Paryżu, gdzie przy wszystkich podejrzeniach i domniemaniach nie wiedziano absolutnie niczego o spisku dojrzewającym na dworze królewskim.

Dnia 20 czerwca 1791 r. Gustaw III otrzymał pomyślne wiadomości ze Sztokholmu. Gustaf Mauritz Armfelt poinformował go bowiem o gotowości Katarzyny II do przekazania Szwedom twierdzy Nyslott

${ }^{40}$ Por. C. v. Stedingk do Gustawa III, Petersburg 3/14 VI 1791, RA, Muscovitica vol. 451. 
i zawarcia układu, którego głównym celem miało być współdziałanie obu sprzymierzeńców w sprawach francuskich i przywrócenie utraconej władzy królowi Francji. Zadowolony $z$ takiego obrotu rzeczy władca Szwecji przewidywał szybkie zakończenie rokowań, tym bardziej że w drogę ze Sztokholmu do Akwizgranu wyruszył, wiozący osobisty list cesarzowej do króla, specjalny wysłannik dworu petersburskiego, generał Piotr A. von Pahlen. Gustaw III, niecierpliwie oczekujący na rezultaty ucieczki Ludwika XVI, snuł uzasadnione przypuszczenia, że do czasu przyjazdu generała Pahlena sprawy francuskie powinny się już definitywnie wyjaśnić, co z kolei powinno ułatwić i przyśpieszyć sfinalizowanie negocjacji z dworem petersburskim. Nie martwił się również zbytnio perspektywą zatrzymania uciekającej z Paryża rodziny królewskiej. Przewidywał bowiem, że wydarzenie to spowodowałoby tak głęboki kryzys w stosunkach międzynarodowych, że dwór petersburski z konieczności zostałby zmuszony do szybkiego zawarcia układu ze Szwecja. Zdaniem Gustawa III również dwór berliński byłby skłonny wesprzeć sprawę Ludwika XVI. Na przeszkodzie w realizacji planów przywrócenia dawnego porządku we Francji stanąc mogła jedynie wroga postawa Anglii oraz ewentualny sprzeciw cesarza wobec planów podpisania szwedzko-rosyjskiego traktatu sojuszniczego. Na razie jednak król szwedzki nie zamierzał martwić się na zapas. Dnia 21 czerwca 1791 r. wyjechał z Akwizgranu do Spa, aby znaleźć się bliżej „wielkiego wydarzenia", które rozgrywało się na terytorium Francji ${ }^{41}$.

Zatrzymanie Ludwika XVI w Varennes (21 czerwca 1791 r.) wpłynęło w bardzo istotny sposób na postępowanie Gustawa III.

${ }^{41}$ Por. Gustaw III do G.M. Armfelta, Akwizgran 21 VI 1791, Bref till Armfelt, s. 185-187. Warte podkreślenia jest również to, że królowi szwedzkiemu zależało na sojuszu $z$ Katarzyna II nie tylko ze względów czysto politycznych. W tym samym liście pisał bowiem do Armfelta: „La plus forte objection, la seule même raisonnable, qu'on pouvait faire contre une coalition de la Suède et de la Russie dans ce moment, était la craintre d'exposer notre commerce au ressentiment de l'Angleterre. Enfin, apres treize ans de souhaits, je me verrai donc enfin lié avec seule souveraine qui soutient l'honneur des têtes couronnées". Co równie ciekawe, szykujac się do udzielenia pomocy Ludwikowi XVI, Gustaw III nie tracił z oczu sprawy swoich zabiegów o koronę polska, pisząc do Armfelta: „Les affaires de Pologne doivent être mises à côté ; je ne regarde pas cela comme fini, mais le tems n'est pas encore arrivé où l'on se battra pour cette nouvelle Helène qui porte une couronne en dot à son époux". Por. ibidem, s. 186. W kwestii ówczesnych działań Gustawa III w sprawach Francji por. też A. Söderhjelm, Sverige..., s. 233; N. Åke s o n, op. cit., Bd I, s. 56; C.T. Odhner, Gustaf III och Katarina II efter..., s. 33-34; Z. Anu sik, Dyplomacja..., s. 354-355; ide m, France..., s. 319. 
Niemal natychmiast po otrzymaniu wiadomości o niepowodzeniu ucieczki rodziny królewskiej władca Szwecji zdecydował się na powrót do Akwizgranu. Tutaj też postanowił czekać na przyjazd generała Pahlena, po spotkaniu $z$ którym wiele sobie obiecywał. Projektowany od dłuższego czasu traktat $z$ Katarzyna II wydawał mu się bowiem w zaistniałej sytuacji jedynym sposobem ratowania monarchii we Francji. Od postawy dworu petersburskiego uzależniał też swoje dalsze postępowanie. Dnia 27 czerwca $1791 \mathrm{r}$. napisał do Gustafa Mauritza Armfelta, że wróci do Szwecji albo w ciągu ośmiu najbliższych dni, albo też $\mathrm{w}$ tym roku nie wróci wcale. Gustaw III nie zamierzał jednak czekać bezczynnie na przyjazd rosyjskiego dyplomaty. Jeszcze tego samego dnia przygotował nowe instrukcje dla swojego ambasadora w Paryżu - barona Erika Magnusa Staëla von Holsteina. Żądał w nich wyraźnie, aby wszystkie jego poczynania były zgodne $z$ nowa polityką dworu sztokholmskiego wobec Francji. Zabraniał też Staëlowi utrzymywania jakichkolwiek stosunków $z$ osobami, które nie byłyby upoważnione do działania bezpośrednio przez Ludwika XVI. Króla Francji uznawał za więźnia nierozporządzającego swobodnie swoją osobą i w zwiąku $z$ tym zabraniał Staëlowi uczestniczenia w konferencjach $z$ tzw. ministrem spraw zagranicznych. W tym samym dokumencie Gustaw III nakazywał ambasadorowi, aby nie podejmował jakichkolwiek działań $z$ własnej inicjatywy i we wszystkim dostosowywał się do postępowania innych ambasadorów. Dostał on również rozkaz wspierania ze wszystkich sił partii królewskiej. Oprócz tego w instrukcjach Gustawa III znalazło się stwierdzenie, że nic nie jest bardziej sprzeczne $z$ interesami władcy Szwecji niż zawarcie porozumienia między Ludwikiem XVI a Zgromadzeniem Narodowym. Celem szwedzkiej polityki wobec Francji jest bowiem „ukręcenie łba hydrze i przywrócenie tam starego porządku”. Staël miał więc działać na rzecz przywrócenia francuskiego tronu rodzinie Bourbonów, restaurowania praw fundamentalnych monarchii i zapewnienia Francji należnego jej miejsca na arenie międzynarodowej. Co ciekawe, Gustaw III zwracał również uwagę na bezpieczeństwo samego ambasadora. Stwierdził bowiem, że po ludziach, którzy nie wahali się podnieść ręki na własnego król, można się spodziewać wszystkiego ${ }^{42}$. W instrukcjach królewskich z 27 czerw-

${ }^{42}$ Por. Gustaw III do G.M. Armfelta, Akwizgran 27 VI 1791, Bref till Armfelt, s. 187-188. Treść instrukcji Gustawa III dla E.M. Staëla v. Holsteina z 27 VI 1791 r. cyt. według A. Söderhjelm, Sverige..., s. 256-257, 259-260. 
ca cele polityki szwedzkiej wobec Francji zostały więc jasno i precyzyjnie zdefiniowane. Gustaw III wykluczał jakiekolwiek rokowania $z$ francuskimi „buntownikami” i zamierzał dążyć do pełnej restauracji ancien regime'u w tym kraju.

Powyższe instrukcje zawiózł do Paryża Erik Bergstedt, już w lutym 1791 r. mianowany przez Gustawa III nowym sekretarzem ambasady szwedzkiej w stolicy Francji. W tym charakterze towarzyszył on swojemu władcy w podróży do Akwizgranu. Nominacja Bergstedta wiązała się bezpośrednio $z$ przejściem dotychczasowego sekretarza misji paryskiej - Arona Isaka Silfversparrego do sztokholmskiej centrali szwedzkiej służby zagranicznej. Od Silfversparrego, który notabene także towarzyszył królowi w jego wojażu do Spa i Akwizgranu, Bergstedt miał przejać obowiązki zaufanego korespondenta Gustawa III w stolicy Francji. Po przyjeździe do Paryża zaczął też pisywać podwójne raporty - oficjalne oraz tajne, przeznaczone wyłącznie dla króla. Rzecz jasna, o tych drugich w ogóle nie był informowany formalny zwierzchnik Bergstedta, ambasador Erik Magnus Staël von Holstein. Wybór Bergstedta na stanowisko sekretarza legacji paryskiej z pewnością nie był przypadkowy. Gustaw III postanowił bowiem wysłać do Paryża człowieka o zdecydowanie konserwatywnych i monarchistycznych pogladach. Bergstedt nie zawiódł też pokładanych w nim nadziei i bardzo szybko okazać się miał zdeklarowanym wrogiem francuskiej rewolucji. Poglądy nowego sekretarza misji paryskiej zjednały mu także poparcie ze strony kilku najbardziej zaufanych doradców Gustawa III. Do grona protektorów Erika Bergstedta zaliczano bowiem Pehra Olofa von Aspa, Hansa Axela von Fersena i Nilsa von Rosensteina. Z sympatia odnosił się również do swego następcy Aron Isak Silfversparre. Nie trzeba dodawać, że wszyscy przyjaciele i protektorzy Bergstedta byli zwolennikami restauracji dawnego porzadku we Francji. Przed swoim wyjazdem z Akwizgranu Bergstedt otrzymał od króla osobne, zbieżne jednak z treścią rozkazów dla ambasadora, instrukcje. Gustaw III nakazywał w nich sekretarzowi legacji paryskiej przeciwdziałanie niekorzystnemu dla interesów Szwecji rozwojowi sytuacji we Francji i działanie na rzecz przywrócenia tam spokoju, porządku i stabilizacji. Można także przypuszczać, że Erik Bergstedt zawiózł do Paryża osobisty list Gustawa III do Ludwika XVI. W liście tym król Szwecji przekazał władcy Francji wyrazy swojego ubolewania i współczucia, zapew- 
niając go równocześnie, że przyjaciele nie opuszczą go w nieszczęściu, a inni królowie już wkrótce pośpieszą mu na pomoc ${ }^{43}$.

Pisząc list do Ludwika XVI w dniu 30 czerwca 1791 r., Gustaw III miał za soba długą rozmowę $z$ Hansem Axelem von Fersenem. Spośród wszystkich uczestników ucieczki rodziny królewskiej z Paryża jedynie Fersen uniknął bowiem zatrzymania w Varennes. Stało się tak dlatego, że w Bourguet otrzymał on od Ludwika XVI polecenie, aby odłączył się od jego świty i zawiózł listy króla do uciekającego w tym samym czasie w kierunku granicy belgijskiej Monsieur, Ludwika hrabiego Prowansji. To polecenie uratowało Fersena. Dnia 22 czerwca o godzinie 6 rano dotarł on do Mons, gdzie spotkał brata królewskiego w otoczeniu licznego orszaku towarzyszących mu dworzan. Jeszcze tego samego dnia Fersen napisał do Everta Taubego, informując go o ucieczce rodziny królewskiej z Paryża. Późnym wieczorem opuścił Mons, spodziewając się już wkrótce dołączyć do dostojnych uciekinierów. Następnego dnia około godziny 23 hrabia Fersen przyjechał do Arlon. Tutaj doszło do nieoczekiwanego spotkania $z$ markizem François Claude'em de Bouillé, od którego dowiedział się o zatrzymaniu rodziny królewskiej w Varennes. Jeszcze tego samego dnia Hans Axel von Fersen napisał list do ojca, w którym znalazło się znamienne stwierdzenie: „Wszystko stracone, mój drogi ojcze, i jestem w wielkiej rozpaczy. Król został zatrzymany w Varennes, 16 mil od granicy". Wobec tak gwałtownego załamania się wszystkich jego planów i nadziei Fersen (zgodnie z wcześniejszymi instrukcjami Ludwika XVI) postanowił pojechać do Brukseli, aby wręczyć listy króla Francji byłemu ambasadorowi Austrii w Wersalu, hrabiemu Françoisowi de Mercy-Argenteau, z którym organizatorzy ucieczki od dawna pozostawali w bezpośrednim kontakcie. Dnia 25 czerwca 1791 r. Fersen dotarł do Brukseli, gdzie odbył pierwsza rozmowę $z$ austriackim dyplomata. Wbrew jego początkowym nadziejom okazało się jednak, że Austriacy nie zrobili dosłownie niczego, aby pomóc $\mathrm{w}$ realizacji opracowanego jeszcze w Paryżu (ze współudziałem barona de Breteuil) planu działania. Ani jeden oddział nie został przesunięty w stronę granicy

43 Por. A. Söderhjelm, Sverige..., s. 242-243, 257-259, 281-282. Por. też Gustaw III do Ludwika XVI, Akwizgran 30 VI 1791, A. v. Fersen, Rescue the Queen. A Diary of the French Revolution 1789-1793 [dalej: Rescue the Queen], eds A. Carlsson, E. Elstob, London 1971, s. 38-39; Z. Anusik, Dyplomacja..., s. 356-357; id e m, France..., s. 32-322. 
francuskiej, a sam François de Mercy-Argenteau nie otrzymał od Leopolda II żadnych instrukcji za wyjatkiem dwóch listów adresowanych do królowej Francji, które miał wręczyć Marii Antoninie po jej przyjeździe do stolicy Brabancji. To dość niefrasobliwe postępowanie cesarza spotkało się $z$ dezaprobata ze strony Fersena, który w swoim dzienniku zapisał: "Typowy Włoch $z$ tego Leopolda”. Fersen nie tracił jednak nadziei i zamierzał zrobić wszystko, co w jego mocy, aby ratować francuska rodzinę królewską $z$ opresji, w która popadła częśsiowo $z$ jego winy. Zapewnienie osobistego bezpieczeństwa Ludwikowi XVI i Marii Antoninie stało się odtąd jednym $z$ najważniejszych celów jego życia. Namiestniczka Niderlandów Austriackich, arcyksiężniczka Maria Krystyna zaproponowała hrabiemu, aby udał się on do Wiednia, żeby szukać pomocy dla Marii Antoniny i Ludwika XVI bezpośrednio u cesarza. Fersen natychmiast podchwycił ten pomysł. Jednocześnie jego przyjaciel, James Quentin Craufurd wystapił z propozycją, że pojedzie do Londynu, aby również na dworze św. Jakuba zabiegać o pomoc dla francuskich Bourbonów. W Brukseli Fersen rozmawiał także $z$ najmłodszym bratem króla Francji, Karolem hrabią d'Artois. Nie wywarł on jednak najlepszego wrażenia na szwedzkim dyplomacie, który wśród cech jego charakteru dostrzegł przede wszystkim wielkopańską niedbałość i zbytnia popędliwość ${ }^{44}$.

Hans Axel von Fersen nie mógł jednak podejmować żadnych akcji dyplomatycznych bez zgody Gustawa III. Dlatego też po kilku dniach opuścił Brukselę i już 29 czerwca 1791 r. zjawił się w Akwizgranie, gdzie następnego dnia spotkał się ze swoim władcą. Król poczatkowo chcial, aby Fersen podjął się misji do dworu londyńskiego. Ten jednak zaproponował wysłanie tam Craufurda, który

${ }^{44}$ Por. Dziennik Fersena, Mons 22 VI, Arlon 23 VI, Bruksela 25 i 28 VI 1791, Rescue the Queen, s. 31-34; Axel von Fersens dagbok [dalej: Fersens dagbok], utg. av A. Söderhjelm, Bd I, Stockholm 1925, s. 82-85; H.A. v. Fersen do E. Taubego, Mons 22 VI 1791, RA, Stafsundsarkivet, Evert Taubes Samling. vol. II; H.A. v. Fersen do A.F. v. Fersena, Arlon 23 VI 1791, Rescue the Queen, s. 32. Ten sam list por. Le comte de Fersen et la cour de France. Extraits des papiers du grand maréchal de Suède, comte Jean Axel de Fersen [dalej: Fersen et la cour de France], publ. par R.M. Klinckowström, t. I, Paris 1877, s. 140. Por. też Gustaw III do G.M. Armfelta, Akwizgran 27 VI 1791, Bref till Armfelt, s. 187; A. Söderhjelm, Sverige..., s. 234; oraz N. Åkes o n, op. cit., Bd I, s. 62. Warto również zwrócić w tym miejscu uwagę na to, że już 27 VI 1791 r. Fersen wysłał do Paryża swojego podwładnego i przyjaciela, porucznika (sztabskapitana w armii szwedzkiej) Andersa Fredrika Reuterswärda $z$ zadaniem informowania go o rozwoju sytuacji wewnętrznej we Francji. Por. H.A. Barto n, Count..., s. 127. 
już wcześniej zgodził się jechać do Anglii. W czasie tej rozmowy udało się również Fersenowi przekonać Gustawa III do pomysłu wyprawienia posła do dworu wiedeńskiego. Nie trzeba dodawać, że jedynym branym pod uwage kandydatem do roli wysłannika króla Szwecji do stolicy Austrii był sam niefortunny organizator ucieczki Ludwika XVI z Paryża. W Akwizgranie Fersen spotkał także dość liczna grupę swoich dawnych znajomych i przyjaciół. Najbardziej ucieszył się jednak ze spotkania $z$ Evertem Taubem, który w pełni podzielał jego przekonanie o potrzebie ratowania francuskiej rodziny królewskiej. Dnia 30 czerwca zjawił się w Akwizgranie również specjalny wysłannik Katarzyny II - generał Piotr A. von Pahlen. To właśnie Taube, Fersen i Pahlen stanowili w początkach lipca 1791 r. grupę najbardziej zaufanych powierników i doradców Gustawa III w sprawach francuskich. Król Szwecji pozostawał także w ścisłym kontakcie $z$ francuskimi książętami, którzy przenieśli się tymczasem do zamku Schönbornlust nieopodal Koblencji. Jeszcze 20 czerwca 1791 r. hrabia d'Artois pisał stamtąd do Gustawa III, że wdzięczny za pamięć i zainteresowanie okazywane mu od początku jego wygnania, wysyła Jeana François barona d'Escars jako swojego reprezentanta $u$ jego boku. W tym samym liście hrabia zapewniał władcę Szwecji, że wszyscy prawdziwi Francuzi, czyli ogromna większość narodu, sa gotowi do przelania krwi w słusznej sprawie i czekają tylko na pomoc ze strony sojuszników i przyjaciół książąt. Przesyłając królowi serdeczne podziękowania za ofertę współdziałania w przywracaniu porządku i ukarania zbrodni we Francji, hrabia d'Artois nie zapomniał również wspomnieć o tym, że list Gustawa III do barona von Brentano bardzo ułatwił poczynania francuskich emigrantów w Stambule. Kontakty z Koblencja nabrały dla króla Szwecji jeszcze większego znaczenia w chwili, gdy do hrabiego d'Artois dołączył jego starszy brat - Ludwik hrabia Prowansji. Teraz bowiem na emigracji znaleźli się obaj bracia Ludwika XVI, którzy w dniu 30 czerwca 1791 r. podjęli decyzję, że wobec faktycznego uwięzienia króla Francji w Paryżu Monsieur obejmie tymczasowo obowiązki regenta ${ }^{45}$.

${ }^{45}$ Por. Dziennik Fersena, Akwizgran 30 VI 1791, Rescue the Queen, s. 38; Fersens dagbok, s. 85; A. Sö d e r hjelm, Sverige..., s. 242, 246; Karol hrabia d'Artois do Gustawa III, Schönbornlust 20 VI 1791, RA, Gallica vol. 521; N. Åke so n, op. cit., Bd I, s. 65; A. Geffroy, op. cit., t. II, s. 167-169. Szerzej o okolicznościach, w jakich doszło do przeniesienia siedziby hrabiego d'Artois $z$ Turynu do Koblencji, por. J. Godechot, La contre-révolution française. Doctrine et 
Decyzja książąt niemal natychmiast została zaaprobowana przez Gustawa III. W liście do Gustafa Mauritza Armfelta $z$ dnia 7 lipca 1791 r. król szwedzki nazywał bowiem hrabiego Prowansji „regentem Francji”. Z ogromną uwagą śledził również zabiegi francuskich emigrantów, którzy podjęli w tym samym czasie starania o uzyskanie posiłków wojskowych od książąt niemieckich. Od wyników rozmów wysłanników „regenta” na dworach niemieckich uzależniał też swoje dalsze postępowanie. Spodziewał się bowiem stanąć na czele armii oddanej przez Niemców do dyspozycji francuskich emigrantów. Armfelta zapewniał, że brakuje mu jedynie odpowiednio licznej armii, żeby mógł już w najbliższym czasie rozpocząć wojnę przeciwko rewolucyjnej Francji. Najbardziej niepokoił się jednak o rezultaty sztokholmskich rokowań $z$ dworem petersburskim. Uzyskanie subsydiów rosyjskich było bowiem warunkiem sine qua non powodzenia planowanej przez niego operacji. Dlatego też już 9 lipca Gustaw III wręczył Pahlenowi sporządzony przez siebie, a przeznaczony dla Katarzyny II memoriał. Pisał w nim, że sprawa Ludwika XVI powinna być traktowana tak, jak gdyby była sprawą wszystkich innych władców europejskich. Zachęcając cesarzowa do udziału w jej rozwiązaniu, prosił ja o wsparcie finansowe i dostarczenie 6-8 tys. żołnierzy rosyjskich na projektowana wyprawę przeciwko Francji. Co ciekawe, już wówczas król Szwecji ostrzegał swoją kuzynkę, by nie pokładała zbyt wielkich nadziei w możliwościach wojskowych francuskich emigrantów. Niemniej jednak on sam przez cały czas utrzymywał $z$ nimi najściślejsze związki. Hrabiego Prowansji zapewniał o chęci wsparcia jego działań na dworach niemieckich. Dziękując królowi za tę inicjatywę, Monsieur pisał $z$ kolei do niego, że nie watpi w to, że negocjacje, do których postanowił się włączyć władca Szwecji, zakończą się sukcesem, a jego przykład skłoni do działania również innych monarchów. Pozostając w bardzo dobrych stosunkach $z$ dworem książąt w Koblencji, Gustaw III zaczął się zastanawiać, czy nie byłoby dla niego lepiej, gdyby otwarcie opowiedział się po stronie emigrantów przeciwko słabemu, chwiejnemu i niekonsekwentnemu królowi Francji. Dnia 10 lipca 1791 r. pisał do Curta von Stedingka, że warta poważnego zastanowienia wydaje się kwestia, kto w aktualnej sytuacji powinien zasiadać na tronie francuskim: Ludwik XVI

action. 1789-1804, Paris 1961, s. 166-167. Por. też Z. Anusik, Dyplomacja..., s. 359-360; id e m, France..., s. 323-324. 
czy też może któryś z jego braci - Ludwik XVII lub Karol $\mathrm{X}^{46}$. Jeśli jednak myśl o detronizacji Ludwika XVI powstała w głowie Gustawa III, to była ona jedynie przelotnym wrażeniem.

Zasady swojej polityki wobec Francji wyłuszczył władca Szwecji w obszernym liście do Gustafa Mauritza Armfelta i Ulrica Gustafa Franca $z 10$ lipca 1791 r. Pisał w nim, że jedyne, do czego zamierza dążyć, to obmyślenie środków, które mogłyby przyśpieszyć decyzję Katarzyny II w sprawie udzielenia przez Rosje pomocy francuskim emigrantom. Ze swojej strony podją już odpowiednie kroki w tym zakresie. Zdecydował się bowiem wysłać do Wiednia hrabiego Hansa Axela von Fersena w celu wywarcia nacisku na cesarza i księcia Antona Wenzela von Kaunitza. Również baron Carl Gustaf Oxenstierna (poseł szwedzki w Ratyzbonie) otrzymał specjalne pełnomocnictwa, aby wesprzeć francuskich książąt w ich rokowaniach dotyczących warunków wynajęcia na czas wojny przeciwko rewolucyjnej Francji oddziałów należących do elektora palatyna Renu. $Z$ misją zaciągnięcia w służbę francuskich emigrantów żołnierzy landgrafa Hesji-Kassel wyprawiony miał też zostać w najbliższym czasie hrabia Nils Anton Barck. Wszystkie plany Gustawa III zależały jednak od wyniku rokowań sztokholmskich. Dlatego też władca Szwecji polecał swoim negocjatorom, aby w przypadku, gdyby cesarzowa zgodziła się zapewnić odpowiednio wysokie subsydia i dostarczyć posiłki wojskowe na wyprawę przeciwko Francji, zrezygnowali $z$ forsowania pomysłu korekty linii granicznej $z$ Rosja i zaprzestali domagania się ustąpienia przez dwór petersburski miejscowości Valkiala i Kärnäkoski. Najważniejsze dla Gustawa III było jak najszybsze zawarcie traktatu sojuszniczego z Rosja, ponieważ każde opóźnienie musiało odwlec ewentualną interwencję w wewnętrzne sprawy Francji aż do wiosny następnego roku. Król przewidywał, że najlepszym miejscem do wysadzenia na ląd interwencyjnych oddziałów szwedzkich i rosyjskich będzie port w Ostendzie. Wattpił bowiem, by udało się dokonać tej operacji w którymś z portów francuskich. Pisząc swój list w dniu 10 lipca 1791 r., Gustaw III nie dysponował jeszcze żadnymi informacjami na temat ewentualnej postawy Anglii wobec projektowanej przez

${ }^{46}$ Por. Gustaw III do G.M. Armfelta, Akwizgran 7 VII 1791, Bref till Armfelt, s. 188-189; A. Söderhjelm, Sverige..., s. 249, 251-252, 253-254; Ludwik hrabia Prowansji do Gustawa III, Schönbornlust 6 VII 1791, RA, Gallica vol. 521; N. Åke s on, op. cit., Bd I, s. 65, 84; Z. Anu sik, Dyplomacja..., s. 360-361; id e m, France..., s. 324-325. 
niego wyprawy. Uważał jednak, że dworowi londyńskiemu zależy jedynie na zyskaniu na czasie i nie ma on żadnych sprecyzowanych planów politycznych ani wobec Szwecji, ani wobec Francji. Co ciekawe, król szwedzki był pełen optymizmu i przewidywał rozpoczęcie działań wojennych przeciwko francuskim rebeliantom już $\mathrm{w}$ najbliższym czasie. Wydał bowiem rozkazy, by natychmiast po podpisaniu traktatu $z$ Rosją rząd sztokholmski rozpoczął działania zmierzajace do ustanowienia regencji na czas jego nieobecności w kraju, zebrania przeznaczonych do udziału w ekspedycji oddziałów wojskowych oraz zapewnienia odpowiedniej liczby statków i okrętów do ich przewiezienia w pobliże granic Francji ${ }^{47}$.

Dnia 12 lipca 1791 r. do Akwizgranu dotarła pierwsza depesza Erika Bergstedta $z$ Paryża. Nowy sekretarz misji szwedzkiej w stolicy Francji pisał o pojawieniu się pogłosek, że Ludwik XVI zaoferować miał Zgromadzeniu Narodowemu uznanie konstytucji i sprowadzenie $z$ powrotem do kraju wszystkich emigrantów pod warunkiem przyjęcia przedstawionych przez niego postulatów. Propozycje królewskie dotyczyć miały zwiększenia zakresu jego uprawnień i wycofania najbardziej kontrowersyjnych dekretów Konstytuanty. Sam Bergstedt nie sadził jednak, żeby postulaty królewskie zostały zaakceptowane. Pozostawały one bowiem w wyraźnej sprzeczności zarówno $z$ ideami wyznawanymi przez większość deputowanych, jak i $z$ nastrojami opinii publicznej. W sumie jednak relacja Bergstedta nie wzbudziła większego zainteresowania Gustawa III. Jego uwaga koncentrowała się bowiem na zupełnie innych zagadnieniach. Dnia 14 lipca król napisał kolejny list do Gustafa Mauritza Armfelta, w którym odniósł się do przewidywanego przez siebie rozwoju wydarzeń na arenie międzynarodowej. Odrzucił zdecydowanie, sugerowana mu przez jednego $z$ najbardziej zaufanych doradców - Andersa Håkansona, możliwość zawarcia sojuszu $z$ dworem kopenhaskim, chociaż przed kilkoma miesiącami brał jeszcze pod uwagę taką ewentualność. Uważał natomiast, że nie powinien

47 Por. Gustaw III do G.M. Armfelta i U.G. Franca, Akwizgran 10 VII 1791, Bref till Armfelt, s. 189-191. W sprawie ustępstw wobec cesarzowej król pisał: „il faut être aussi généreux que l'Impératrice et sacrifier quelques rochers pour secourir une maison royale opprimée". Por. ibidem, s. 190. W kwestii przeszkód w skorzystaniu $z$ portów francuskich Gustaw III pisał dosłownie: „puisqu'il est incertain si l'on pourra se saisir de quelque port de France, depuis que la fuite et l'arrestation du roi ont éveillé un esprit de surveillance et d'inquiétude qui pourra déchacer de semblables projets". Por. ibidem; oraz N. Åke s o n, op. cit., Bd I, s. 86; Z. An u sik, Dyplomacja..., s. 361-362; id e m, France..., s. 325-326. 
mieć specjalnych trudności $z$ zawarciem układu subsydiowego $z$ Hiszpanią. Jego zdaniem dwór madrycki, obserwujący z niepokojem rozwój sytuacji we Francji i pozostający w zaostrzającym się coraz bardziej konflikcie $z$ Anglia, powinien być zainteresowany zbliżeniem tak do Szwecji, jak i do jej nowej sojuszniczki - cesarzowej Rosji ${ }^{48}$.

W tym samym liście Gustaw III odniósł się także do swoich planów dotyczących polityki wewnętrznej. Przekonywał swoich najbliższych współpracowników, że w Szwecji należy w pierwszej kolejności zgnieść opozycję demokratyczną. Uważał bowiem, że wszędzie tam, gdzie pojawią się „jakobini”, należy się spodziewać ich dążenia do obalenia istniejącego porządku. $Z$ tego faktu wysnuwał Gustaw III paradoksalny na pozór wniosek. W jego przekonaniu, żeby doprowadzić do uspokojenia sytuacji w Szwecji, należało zrobić wszystko, aby przywrócić silną władzę królewską we Francji. To bowiem zapewnić miało Szwecji regularną wypłatę (przewidzianych w wygasłym już traktacie $z 19$ lipca 1784 r.) francuskich subsydiów. Król przewidywał zresztą, że $z$ łatwością uda mu się uzyskać zwiększenie wypłat ze strony Francji po przywróceniu tam zasad ancien regime'u. Drugim celem polityki wewnętrznej Gustawa III miało być doprowadzenie do ugody $z$ antykrólewska opozycja liberalnej arystokracji. Miało to zapobiec zarówno niepokojom wewnętrznym, jak i dążeniom trzech stanów nieuprzywilejowanych do dalszego ograniczenia przywilejów stanu szlacheckiego. Pogodzenie się $z$ opozycją szlachecką uważał król za rzecz trudną, ale możliwą. Przewidywał jednak, że będzie mógł zwołać nowy riksdag i rozpoczać rozmowy z przedstawicielami opozycji dopiero po ostatecznym uregulowaniu spraw francuskich. Bardzo dużą uwage przywiazywał także do kwestii rokowań z Rosją. Za najbardziej istotna uznawał w tym czasie kwestię artykułu dotyczacego określenia wysokości rosyjskich subsydiów dla Szwecji. Król uważał, że możliwa do zaakceptowania przez obie strony byłaby suma 500 tys. rubli rocznie. Gdyby jednak dwór petersburski nastawał na wprowadzenie do treści traktatu artykułu przewidującego wspólna akcję przeciwko Prusom, wówczas Katarzyna II powinna - zdaniem Gustawa III - dorzucić jeszcze następnych 500 tys. rubli rocznie, co zresztą i tak nie stanowiłoby wystarczającej rekompen-

48 Por. E. Bergstedt do Gustawa III, Paryż 6 VII 1791, RA, Gallica vol. 476; oraz Gustaw III do G.M. Armfelta, Akwizgran 14 VII 1791, Bref till Armfelt, s. 192-193; Z. Anusik, Dyplomacja..., s. 362. 
saty dla Szwecji, która decydując się na podpisanie traktatu pokojowego $z$ Rosja, utraciła subsydia wypłacane jej dotąd przez Turcję. Równie interesujace wydaje się to, że Gustaw III polecił Armfeltowi podjęcie starań w celu zapewnienia wypłaty przez cesarzowa dodatkowych środków na dofinansowanie prywatnego skarbu królewskiego. Wszystko to świadczy niezbicie o krytycznym położeniu finansowym Gustawa III, któremu nawet najbardziej oddani doradcy podsuwali myśl o zwołaniu nowego riksdagu. Król odrzucał jednak zdecydowanie taką możliwość. Mając do wyboru: stawić czoła narastającej opozycji wewnętrznej czy organizować monarchistyczna krucjatę przeciwko rewolucyjnej Francji, opowiedział się bez wahania po stronie tego drugiego rozwiązania ${ }^{49}$.

Szykujac się do interwencji we Francji, Gustaw III myślał także poważnie o tym, aby zapewnić minimum bezpieczeństwa francuskiej rodzinie królewskiej. Polecił więc Erikowi Bergstedtowi, aby spróbował nawiązać bezpośredni kontakt z królem i królową. Dnia 17 lipca do Akwizgranu nadeszła odpowiedź od sekretarza misji paryskiej. Bergstedt pisał, że obecny kryzys sprawił, że nie został on jeszcze przedstawiony ani ministrowi spraw zagranicznych, ani korpusowi dyplomatycznemu. $Z$ tego względu, nie uzyskawszy jeszcze formalnej akredytacji przy dworze paryskim, nie mógł się starać o audiencję w Tuileriach. Nie wyobrażał też sobie, aby udało mu się dostać do pałacu incognito. Para królewska była bowiem bardzo dobrze strzeżona i wpuszczano do niej tylko osoby ze specjalnej listy, układanej każdego dnia przez Ludwika XVI i zatwierdzanej przez jego nadzorców. Sądzić też można, że Bergstedt nie zamierzał ryzykować samowolnego wtargnięcia do siedziby królewskiej. W dalszej części swojej depeszy pisał bowiem, że każdy podejrzany o intrygowanie w celu uwolnienia króla będzie powieszony na latarni bez żadnego miłosierdzia. Twierdził także, że hrabia Fersen miał wiele szczęścia, że udało mu się uniknać wściekłości ludu i nigdy nie powinien wracać do Paryża. Charakteryzując nastroje panujące ówcześnie we Francji, Bergstedt pisal, że Zgromadzenie Narodowe (Konstytuanta) gotowe jest bronić kraju przed wszelka obca interwencją. Nie obawia się jednak najazdu, gdyż powszechnie jest przekonanie, że interwentów będzie można pobić ich własnymi rękami, przeciagając żołnierzy na stronę rewolucji. Wedle relacji szwedzkiego dyplomaty, w Paryżu dominował też pogląd,

49 Por. Gustaw III do G.M. Armfelta, Akwizgran 14 VII 1791, Bref till Armfelt, s. 193-196; Z. Anusik, Dyplomacja..., s. 362-363; id e m, France..., s. 327. 
że w najbliższym czasie nie dojdzie do utworzenia żadnej ligi antyfrancuskiej. Zdaniem Francuzów cesarz pochłonięty był bowiem wyłącznie rokowaniami z Turcją w Szystowej (Sistowej), król pruski zajęty był sprawą tejże Turcji i Polski, a książęta niemieccy byli zbyt słabi i zbyt podzieleni, aby mogli stanowić jakiekolwiek zagrożenie dla rewolucji. Lekceważąc całkowicie możliwości państewek włoskich oraz Hiszpanii, Zgromadzenie Narodowe obawiało się jedynie Wielkiej Brytanii, która mogłaby pokusić się o zagarnięcie francuskich kolonii. W tej samej depeszy Bergstedt pisał, że od czasu przyjazdu Gustawa III do Akwizgranu uważa się to miasto za centrum kontrrewolucji i siedlisko knowań skierowanych przeciwko wolności Francji. Ponieważ jednak istniała obawa, że król szwedzki może stanąc na czele wyprawy władców przeciwko rewolucji, sekretarz misji paryskiej zapewniał swojego władcę, że oba zwalczające się w Konstytuancie stronnictwa będą dążyły do zapewnienia sobie przychylności z jego strony. Bergstedt był także przekonany o tym, że pierwsze mocarstwo, które sprzymierzy się ze Zgromadzeniem Narodowym, będzie mogło liczyć na wielkie korzyści. Znając jednak doskonale usposobienie Gustawa III, nawet nie próbował sugerować, aby mocarstwem tym była Szwecja ${ }^{50}$.

Tymczasem Gustaw III czynił dalsze postępy na drodze do przyszłej interwencji we Francji. W Akwizgranie spotkał się z markizem de Bouillé, który już wcześniej zdecydował się podjać (aczkolwiek w dość luźnej i bliżej nieokreślonej formie) współpracę $z$ braćmi Ludwika XVI. Na naradzie $z$ udziałem króla, markiza i Everta Taubego uzgodniono też szczegóły dotyczące współdziałania wojsk szwedzkich $z$ francuskimi emigrantami. Jako miejsce lądowania oddziałów Gustawa III wybrano wówczas Normandię. Gdyby jednak lądowanie w którymś z portów francuskich okazało się niemożliwe, wojska szwedzkie miały zostać wysadzone na brzeg w belgijskiej Ostendzie. To drugie rozwiązanie od początku wydawało się zreszta królowi bardziej realne. Opracowane przez niego samego (przy współudziale Everta Taubego) plany przyszłej kampanii zakładały bowiem, że wojska przeznaczone do udziału w wyprawie do Francji zbiora się w Öresundzie lub w Göteborgu i stamtąd zostana przerzucone właśnie do Ostendy. Co ciekawe, Gustaw III przewidywał, że całą operację uda mu się zrealizować już w końcu sierpnia. Opty-

50 Por. E. Bergstedt do Gustawa III, Paryż 11 VII 1791, RA, Gallica vol. 476. Por. też A. Söderhjelm, Sverige..., s. 287; N. Åkes on, op. cit., Bd I, s. 60; Z. Anu sik, Dyplomacja..., s. 363-364; id e m, France..., s. 327-328. 
mistą wydawał się także generał de Bouillé. Był on niemal pewien, że niebawem wojska szwedzkie pojawia się w pobliżu granic Francji. $Z$ tego właśnie powodu jego syn, młody hrabia Louis Joseph podjął decyzję o wstąpieniu do służby w armii szwedzkiej, a sam markiz przystapił do sztabowego opracowania planów przyszłych operacji militarnych ${ }^{51}$. W połowie lipca 1791 r. ani Gustaw III, ani markiz de Bouillé nie mogli jednak jeszcze wiedzieć, że ich plany dotyczące Francji trzeba będzie odłożyć na później. Rokowania sztokholmskie nie przyniosły bowiem na razie oczekiwanych w Akwizgranie rezultatów. Katarzyna II wyraźnie grała na zwłoke i przesyłała do Sztokholmu instrukcje usztywniajace stanowisko rosyjskich negocjatorów. Cesarzowa nie tylko odmawiała pożądanych przez Szwecję ustępstw w sprawie korekty granic, lecz nie czyniła także wielkich nadziei na wypłatę subsydiów, bez których szwedzka interwencja we Francji była po prostu niemożliwa do zrealizowania. W tej sytuacji nie dziwi postawa Gustafa Mauritza Armfelta, który ostrzegał swego władcę, że słabość emigrantów może wystawić na ogromne niebezpieczeństwo projektowaną przez niego wyprawę. Najbardziej zaufany doradca pisał też do Gustawa III, że szwedzka armia i flota będa gotowe do działania dopiero w końcu października. Armfelt był zresztą od początku dość sceptyczny wobec planów króla i wyrażał obawy o losy całego przedsięwzięcia, spodziewając się zarówno silnej opozycji wewnętrznej, jak i niechęci ze strony innych władców europejskich ${ }^{52}$.

${ }^{51}$ Por. A. Söderhjelm, Sverige..., s. 248-250; e adem, Revolutionärer..., s. 81; eadem, Fersen et Marie-Antoinette. Journal intime et correspondance du comte Axel de Fersen, Paris 1930, s. 199; N. Åke s o n, op. cit., Bd I, s. 57, 71, 110; Z. Anusik, Dyplomacja..., s. 364-365; ide m, France..., s. 328-329.

${ }^{52}$ W liście Katarzyny II do Ottona Magnusa von Stackelberga, który notabene przekazał kopię tego listu Armfeltowi, znalazły się m.in. następujące sformułowania: „Mais s'il faut enfin venir à quelque troc de frontière, il est nécessaire que l'égalité sert de base, car je ne veux ni perdre, ni gagne; et je vous defends expressément d'entrer en aucune espèce de discussion sur la cession de Högfors, puisque l'opinion publique a fait considérer cet endroit comme nécessaire à notre défence. A l'égard de l'argent, vous connaissez mes finances tout aussi bien que moi. Je peux faire des envois pour mon ami et mon parent, mais je n'ai rien en commun avec les finances et les dettes de la Suède". Por. G.M. Armfelt do Gustawa III, Sztokholm 17 VII 1791, Bref till Armfelt, s. 189. Szczegółowe omówienie przebiegu rozmów sztokholmskich i stanowiska Katarzyny II wobec Francji por. C.T. Odhner, Gustaf III och Katarina II efter..., s. 34-37; I. de Madariaga, op. cit., s. 422 . $Z$ przytoczonych przez tych badaczy dokumentów wynika, że carowa gotowa była podjać działania w celu przywrócenia Francji miejsca w koncercie mocarstw europejskich. W tym celu zgadzała się zaoferować Gustawowi III 
Zanim jednak ostrzeżenia Armfelta dotarły do rak Gustawa III, ten ostatni rozwiną zakrojona na szeroka skalę akcję dyplomatyczną. O swoich planach w tym zakresie informował król Armfelta już w swoim liście $z 10$ lipca 1791 r. W ciagu kilkunastu następnych dni plany królewskie zostały wcielone w życie. Zgodnie $z$ wcześniejszymi ustaleniami do Wiednia wysłany został hrabia Hans Axel von Fersen. Równie ważne poselstwo powierzone zostało Evertowi Taubemu, który wyruszyć miał do Koblencji, gdzie przebywali obaj młodsi bracia Ludwika XVI. Pomysł króla, który uważał, że w przyszłej interwencji we Francji najważniejszą rolę obok Austrii, Rosji i Szwecji powinni odegrać francuscy emigranci, zdecydowanie nie podobał się Fersenowi. Zaufany przyjaciel Marii Antoniny od początku myślał bowiem o przywróceniu pełni władzy francuskiej parze królewskiej i $z$ tego powodu opowiadał się przeciwko wysuwaniu na plan pierwszy ksiąząt, stanowiących realne zagrożenie dla Ludwika XVI. Gustaw III nie myślał jednak przejmować się dąsami swojego dyplomaty i konsekwentnie realizował uzgodniony wcześniej z Evertem Taubem plan działania. Ponieważ zaś podpisana w dniu 24 maja w Sztokholmie tajna konwencja preliminaryjna $z$ Rosja przewidywała, że w projektowanej wyprawie przeciwko Francji obok 16 tys. Szwedów i 8 tys. Rosjan weźmie również udział 12 tys. żołnierzy heskich, hrabia Nils Anton Barck wyjechał do Kassel, aby negocjować $z$ landgrafem warunki wynajęcia jego oddziałów. Zadanie postawione przed młodym dyplomata było zreszta niezmiernie trudne. Funduszy na sfinansowanie tego przedsięwzięcia dostarczyć miał bowiem dwór londyński. Problem polegał jednak na tym, że dopiero 18 lipca 1791 r. Gustaw III napisał do Gustafa Adama von Nolckena, posła szwedzkiego w Londynie, zalecając mu podjęcie starań o angielskie subsydia dla landgrafa heskiego na Kassel. Podczas pobytu w Akwizgranie król szwedzki wpadł również na pomysł, aby zwrócić się o pomoc do elektora bawarskiego. Wydał więc rozkaz baronowi Carlowi Gustafowi Oxenstiernie, posłowi szwedzkiemu przy sejmie Rzeszy w Ratyzbonie, aby udał się do Monachium, gdzie miał podjąc starania o uzyskanie posiłków wojskowych przeciwko rewolucyjnej Francji. Dnia 16 lipca Gustaw III napisał też osobisty list do króla Hiszpanii - Karola IV, zapowiadając wysłanie do Francji 16 tys. swoich żoł-

500 tys. rubli rocznego subsydium i 10 tys. żołnierzy. W kwestii stosunku Armfelta do projektowanej przez króla wyprawy do Francji por. A. Söderhjelm, Sverige..., s. 261-262. Por. też Z. A nu sik, Dyplomacja..., s. 365. 
nierzy i prosząc dwór madrycki o subsydium w wysokości $12 \mathrm{mln}$ liwrów. Przystępując do montowania antyfrancuskiej koalicji, król szwedzki nie zapomniał także o dworze berlińskim. Dnia 23 lipca 1791 r. jego poseł w Berlinie - Christian Ehrenfried von Carisien otrzymał rozkaz nakłonienia Prus do przystapienia do projektowanej ligi władców, która miała się upomnieć o pogwałcone prawa Ludwika XVI. Wysłany tego samego dnia z Akwizgranu do Londynu James Quentin Craufurd otrzymał dokładnie takie samo polecenie $\mathrm{w}$ odniesieniu do dworu angielskiego ${ }^{53}$. Uprzedzając nieco dalszy bieg wypadków, zaznaczmy w tym miejscu, że żaden $z$ wysłanników króla Szwecji nie zdołał zrealizować celu swojej misji. Na każdym dworze szwedzcy dyplomaci napotkali na trudności, których nie potrafili przezwyciężyć. Wszyscy władcy w ten lub inny sposób zdystansowali się bowiem od przedstawionych im propozycji współdziałania przeciwko rewolucyjnej Francji.

Wyprawiwszy swoich posłów do dworów, od których spodziewał się uzyskać pomoc zbrojna lub finansowa, Gustaw III rozpoczą przygotowania do powrotu do Szwecji. Zdał sobie bowiem sprawę $z$ tego, że projektowana wyprawa przeciwko rewolucyjnej Francji będzie mogła dojść do skutku najwcześniej za kilka miesięcy. Niemal w przeddzień wyjazdu dotarła do króla kolejna depesza od Erika Bergstedta. Sekretarz misji paryskiej pisał w niej, co następuje: „Dwaj oficerowie szwedzcy, panowie Fieandt i König przybyli do mnie wczoraj i powiedzieli mi, że zostali wysłani przez Wasza Wysokość z zadaniem rozpoznania biegu Sekwany od Paryża aż do Hawru i że pan baron Wrede uprzedził ich, zgodnie $z$ rozkazem Waszej Wysokości, że powinni mnie o tym poinformować. Ponieważ wcześniej nie otrzymałem w tej sprawie żadnych rozkazów, byłem bardzo zakłopotany tymi przejawami zaufania. Nie wahałem się jednak udzielić im przestróg i zaopatrzyć ich w mapy nowych departamentów, które zostały opublikowane już po wybuchu rewolucji. To była zreszta jedyna rzecz, jaka mogłem dla nich zrobić, nie znając jeszcze tego kraju na tyle dobrze, aby udzielić im jakichś użytecznych wiadomości i nie ośmielając się mieszać zbyt mocno w sprawę, która mogłaby mieć dla mnie bardzo nieprzyjemne następstwa, gdyby została wykryta". O ile misja kapitana Fieandta i korneta Königa mogła stanowić zaskoczenie dla Bergstedta, to nie

53 Por. A. Söderhjelm, Sverige..., s. 247, 250-251; N. Åkeson, op. cit., s. 68-69, 72-73, 74-75, 76, 80-81; Z. Anu sik, Dyplomacja..., s. 366-367; id e m, France..., s. 330. 
była ona rzecz jasna żadna niespodzianką dla Gustawa III. Jeszcze w czerwcu rozkazał on bowiem Armfeltowi, aby wysłał do Francji dwóch kartografów $z$ zadaniem rozpoznania drogi $z$ Hawru do Paryża. Król szwedzki spodziewał się, że już wkrótce droga ta poprowadzi swoich żołnierzy na pomoc udręczonemu Ludwikowi XVI. $\mathrm{Na}$ razie jednak musiał się zajać innymi sprawami. Dnia 25 lipca 1791 r. Gustaw III opuścił więc Akwizgran, udając się w drogę powrotną do Szwecji ${ }^{54}$.

Gustaw III powrócił z Akwizgranu do swojej stolicy w dniu 3 sierpnia 1791 r. Niemal natychmiast jego rezydencja w Drottningholmie została przekształcona w główną kwaterę kontrrewolucji. Tu bowiem nadchodziły raporty od Everta Taubego, Nilsa Antona Barcka i Carla Gustafa Oxenstierny. Tu wreszcie napływały doniesienia z Madrytu, Wiednia i Petersburga. Przez cały czas król pozostawał też w kontakcie ze swoimi dyplomatami. Szczególną wage przykładał jednak do wiedeńskiej misji Hansa Axela von Fersena. Już 5 sierpnia $1791 \mathrm{r}$. zrelacjonował mu szczegółowo przebieg swojej rozmowy $z$ Charles'em de Calonne, który przyjechał do Akwizgranu nazajutrz po wyjeździe Fersena. W czasie tego spotkania omawiano ewentualność uzyskania angielskich posiłków przeciwko Francji. Zarówno król, jak i Calonne mieli nadzieję, że dwór londyński przeznaczy do tej wyprawy oddziały hanowerskie. Gustaw III szybko doszedł jednak do wniosku, że ostateczna decyzja w tej sprawie pozostaje pod dużym znakiem zapytania. Pocieszał się natomiast myślą, że zarówno William Pitt, jak i Jerzy III obiecali Calonne'owi zachowanie pełnej neutralności w sprawach francuskich. W tym samym liście król informował swojego wysłannika na dwór wiedeński, że wiadomość o nieszczęściach Ludwika XVI wywarła wielkie wrażenie na Katarzynie II. Twierdził także, że spodziewane zawarcie pokoju rosyjsko-tureckiego bardzo ułatwi cesarzowej podjęcie skutecznych działań na rzecz Francji. Kilka dni później Gustaw III rozkazał Fersenowi, aby popierał on w Wiedniu działania podejmowane przez hrabiego Barcka w Kassel. Sam król zdawał się jednak wattpić w możliwość nakłonienia landgrafa do podpisania układu ze Szwecją. Pisał bowiem, że władca Hesji wysuwa tak ekstrawaganckie żądania, jak gdyby $z$ góry spodziewał się odmowy ich spełnienia. Zainteresowanie Gustawa III sprawami francuskimi nie

${ }^{54}$ Por. E. Bergstedt do Gustawa III, Paryż 18 VII 1791, apostille, RA, Gallica vol. 476; A. Söderhjelm, Sverige..., s. 260; N. Åkes on, op. cit., Bd I, s. 84, 132-133; Z. Anusik, Dyplomacja..., s. 367. 
uszło uwagi sfer dworskich Sztokholmu. Pisała o tym wyraźnie jego szwagierka, Hedvig Elisabeth Charlotta w liście do swojej przyjaciółki Sophie Piper. Księżna przekazała też siostrze Hansa Axela von Fersena znamienną informację, że w czasie przedstawienia w teatrze król powiedział do niej: „mam nadzieję, że w ciagu 3 lub 4 miesięcy wszystko [we Francji - przyp. Z.A.] powróci do dawnego porządku" 55 .

Sądzić można, że Gustaw III rzeczywiście wierzył w możliwość rychłego przywrócenia we Francji zasad dawnego porządku. Jego dobrego nastroju nie zmącił nawet list od jednego $z$ największych feudałów francuskich, znanego ze swoich liberalnych poglądów deputowanego Konstytuanty, Armanda de Vignerot du Plessis de Richelieu księcia d'Aiguillon, który przesłał mu świeżo wydrukowany egzemplarz nowej konstytucji. Wiedzac o wrogich zamiarach króla wobec jego ojczyzny, książę nie wahał się napisać: „Życzyłbym sobie gorąco, aby Wasza Wysokość, czytając uważnie to dzieło rozumu i filozofii, które prawdopodobnie jest spotwarzane w Jego oczach, zechciał mu oddać sprawiedliwość, na która według mnie zasługuje. $Z$ niecierpliwością będę też oczekiwał na wieści, spodziewając się otrzymać dla nowego prawa mojej ojczyzny, którego Francuzi sa zdecydowani bronić aż do śmierci, pochwałę ze strony oświeconego monarchy i uczciwego człowieka. Będę także czekał na zapewnienie, że zechce on respektować wolną wolę dumnego i szlachetnego narodu, który pragnie pozostać wiernym sojusznikiem ludu Szwecji"56. Ponieważ treść tego listu pozostawała w całkowitej sprzeczności z poglądami wyznawanymi przez Gustawa III, należy przypuszczać, że władca Szwecji nie zaszczycił księcia d'Aiguillon żadną odpowiedzią.

O wiele więcej radości sprawił królowi list, który otrzymał w końcu sierpnia od markiza de Bouillé. Generał pisał w nim, że zgodnie $z$ rozkazami Gustawa III przekazanymi mu przez barona de Breteuil nie robi na razie niczego w sprawie przygotowania projektowanych operacji wojskowych, czekając na ostateczna decyzję króla. Informował jednak władcę Szwecji, że w Luksemburgu znajduje

55 Por. N. Åkes on, op. cit., Bd I, s. 130; C.T. Odhner, Gustaf III och Katarina II efter..., s. 44-45; Gustaw III do H.A. v. Fersena, Drottningholm 5 i 9 VIII 1791 oraz apostille do depeszy z 5 VIII 1791, RA, Stafsundsarkivet, Hans Axel von Fersens Samling, vol. 11. Por. też Hedwig Elisabeth Charlotta księżna Sudermanii do S. Piper, Sztokholm 7 VIII 1791, cyt. według A. Söderhjelm, Sverige..., s. 274. Por. również Z. Anu sik, Dyplomacja..., s. 431.

56 Por. A. ks. d’Aiguillon do Gustawa III, Paryż 4 VIII 1791, RA, Gallica vol. 524. 
się artyleria oblężnicza, która może zostać wykorzystana w działaniach wojennych przeciwko Francji. Bouillé wspomniał także o zamiarze wydania przez cesarza i króla pruskiego wspólnego manifestu w sprawach Francji (co rzeczywiście nastąpiło kilkanaście dni później). Jego zdaniem król pruski wyrazić miał życzenie, aby wydanie manifestu poprzedziło rozpoczęcie właściwych działań zbrojnych. Markiz był jednak przekonany o tym, że dwory niemieckie zaczekają na wyjaśnienie postawy Anglii, zanim zdecydują się na rozpoczęcie jakichkolwiek działań przeciwko Francji. W tym samym liście generał pisał, że Fryderyk Wilhelm II zaproponował mu opracowanie planu wspólnych działan połączonych armii. W związku $z$ tym markiz starał się przekonać do tego pomysłu również braci Ludwika XVI. Uważał bowiem opracowanie takiego planu za gwarancje przyszłych sukcesów armii koalicyjnych. Generał przekonywał także Gustawa III o konieczności gromadzenia na granicach Francji żywności i sprzętu wojennego. Uprzedzając rozkazy królewskie, przedstawił też ksiażętom w Koblencji plan rozmieszczenia armii szwedzkiej na wybranych przez niego terenach nad Mozą. Sam Bouillé nie był jednak pewien, czy rada książęca zatwierdzi tę propozycję i czy zgodzą się na nią inne mocarstwa. Nawiąując do spraw wielkiej polityki, markiz pisał z kolei, że należy przypuszczać, że cesarz zamierza konsultować swoje zamiary względem Francji przede wszystkim $z$ władcami $z$ domu Bourbonów, z Anglią i z Prusami. Dopiero po zaakceptowaniu jego planów przez te dwory można się będzie spodziewać przedstawienia ich Szwecji, Rosji i kantonom szwajcarskim. Bouillé ostrzegał jednak króla, że dwory niemieckie moga być niechętnie usposobione wobec pomysłu udziału wojsk szwedzkich i rosyjskich w dziele restauracji monarchii we Francji. I nawet jeśli nie będą one ujawniać widocznej opozycji, to nie należy się spodziewać żadnego poparcia $z$ ich strony dla starań dworu sztokholmskiego o uzyskanie subsydiów na planowana wyprawę. Przewidując przyszłe trudności, markiz napisał więc do przebywającego w Madrycie Paula François księcia de La Vauguyon, prosząc go o rozpoczęcie zabiegów na rzecz uzyskania hiszpańskich subsydiów dla króla Szwecji. Zgodnie $z$ jego propozycją Hiszpania miała zaciągnąć w Holandii pożyczkę w wysokości $12 \mathrm{mln}$ florenów (przekazując następnie cała tę sumę Gustawowi III) i wesprzeć zabiegi króla o wynajęcie żołnierzy landgrafa heskiego. Będąc przekonanym, że poparcie sprawy Ludwika XVI przez Szwecję i Rosję będzie dla Francji dużo mniej 
niebezpieczne niż ewentualna pomoc ze strony Austrii i Prus, markiz zapewniał księcia de La Vauguyon, że przedstawione przez niego propozycje pochodza $z$ dworu książąt w Koblencji. Czynił tak dlatego, aby w najmniejszym nawet stopniu nie kompromitować Gustawa III, który nie upoważnił go do występowania w swoim imieniu. $Z$ obserwacji ostatnich wydarzeń na arenie międzynarodowej Bouillé nie wyciagał jednak zbyt optymistycznych wniosków. Twierdził co prawda, że jeśli dwory wiedeński i berliński chciałyby naprawdę działać na rzecz przywrócenia monarchii we Francji, to nic nie powinno im przeszkodzić. Niepokoiło go jednak widoczne rozbicie wśród mocarstw europejskich. Obawiał się także, żeby negocjacje $z$ nowym rządem francuskim nie doprowadziły do ugody, która byłaby bardzo niebezpieczna dla całej Europy, jeśli we Francji zostałby utrzymany dotychczasowy stan rzeczy, stanowiacy niebezpieczny przykład dla wszystkich ludów. Zapowiadając swój wyjazd na Śląsk, gdzie miał się spotkać $z$ królem pruskim, markiz zapewniał równocześnie Gustawa III, że wróci na czas, aby wykonać jego rozkazy w sprawie przyjęcia i rozmieszczenia armii szwedzkiej w pobliżu granic Francji. O wszystkich swoich posunięciach Bouillé informować miał także Hansa Axela von Fersena ${ }^{57}$.

Hrabia Fersen był zreszta na bieżąco informowany również o wszystkich działaniach Gustawa III. Kiedy bowiem do Sztokholmu dotarła datowana na dzień 13 sierpnia 1791 r. odpowiedź Jerzego III na wcześniejszy list władcy Szwecji, ten ostatni natychmiast wysłał do Wiednia specjalnego kuriera $z$ kopia listu króla angielskiego. Na przełomie sierpnia i września uwage króla pochłaniało jednak głównie przygotowanie planów militarnej interwencji we Francji. Gustaw III od poczattku był zwolennikiem przeprowadzenia restauracji tronu Ludwika XVI z użyciem niewielkich sił wojskowych. Twierdził bowiem, że 120-tysięczna armia może tylko rozpętać wojnę, podczas gdy 20-tysięczna w zupełności wystarczy do przywrócenia dawnej władzy królowi. Już w początkach sierpnia $1791 \mathrm{r}$. był też gotowy projekt lądowania oddziałów szwedzkich w Normandii. Zakładano w nim, że inwazji dokona korpus liczacy 6-7 tys. żołnierzy, a jako miejsce przyszłego lądowania przewidywano Cherbourg, La Hogue lub Fosse de Coleville. Po kolejnych konsultacjach $z$ Evertem Taubem Gustaw III dokonał jednak istotnych poprawek $\mathrm{w}$ tym projekcie. Uzgodniony w początkach wrze-

57 Por. F.C. de Bouillé do Gustawa III, Aschaffenburg 11 VIII 1791, ibidem. Por. też Z. Anu sik, Dyplomacja..., s. 432-433; oraz id e m, France..., s. 390-391. 
śnia plan lądowania w Normandii przewidywał, że w inwazji na tę prowincję weźmie udział 30 tys. żołnierzy, a od strony Flandrii będa prowadzone dodatkowe działania osłonowe. Wobec braku zgody cesarza na udostępnienie portu w Ostendzie król poważnie myślał o wykorzystaniu któregoś $z$ portów angielskich. Do udziału w wyprawie szykował 16 tys. żołnierzy. Liczył także na to, że Katarzyna II dostarczy mu korpus posiłkowy w sile 10 tys. ludzi. W wyprawie miały także wziąć udział oddziały francuskich emigrantów. Niezbędnym warunkiem rozpoczęcia całej akcji było jednak uzyskanie rosyjskich subsydiów, które miały umożliwić Gustawowi III sfinansowanie własnych zbrojeń ${ }^{58}$.

O swoich ostatnich posunięciach, jak również o planach na najbliższa przyszłość pisał król szczegółowo w liście do Curta von Stedingka z 13 września 1791 r. Nakazał mu wyjaśnić cesarzowej, że dalsza zwłoka w działaniu naraża na ogromne niebezpieczeństwo Ludwika XVI oraz jego rodzinę. Przedstawiając swoje dotychczasowe poczynania, król przypomniał, że jeszcze w czasie pobytu w Akwizgranie przedstawił palatynowi Renu i landgrafowi Hesji propozycję wynajęcia ich oddziałów wojskowych. Spotkał się jednak z opieszałością i niezdecydowaniem, które w jego opinii dominować miały we wszystkich gabinetach europejskich. Gustaw III pocieszał się jednak myślą, że jeśli cesarz weźmie udział w wojnie, inni książęta niemieccy pójdą za jego przykładem. W dalszej części tego listu król informował Stedingka, że do Wiednia wyprawił Hansa Axela von Fersena, a do króla Anglii wysłał list przez hrabiego de Mercy-Argenteau. Napisał także do Williama Pitta, aby poznać jego opinię w sprawach Francji. Z Londynu otrzymał bardzo dobre wiadomości. Jerzy III zadeklarował bowiem pełna neutralność, dając innym władcom wolna rękę w dziele ratowania Ludwika XVI. Ponieważ zaś w Pillnitz cesarz obiecał, że przyjdzie z pomocą władcy Francji, Fersen otrzymał polecenie, aby naciskał na Leopolda II, starając się skłonić go do podjęcia definitywnej decyzji w tej spra-

58 Por. N. Åkeson, op. cit., Bd I, s. 116-117, 124, 127-128, 133-134. Por. też E. Taube do Gustawa III, Akwizgran 8 VIII 1791, Fersen et la cour de France, s. 180. W działaniach przeciwko Francji król zamierzał użyć wojsk austriackich, rosyjskich, pruskich, szwedzkich, hiszpańskich, sardyńskich, angielskich, hanowerskich, heskich i niemieckich. W sumie stanowić to miało 100 tys. ludzi pod jego własnym dowództwem. Większość tych sił miała być jednak wykorzystana do działań osłonowych. Por. C.G. N or d in, Dagboksanteckningar för åren 1786-1792, [w:] Historiska Handlingar, Bd VI, Stockholm 1868, s. 172 (zapiska z 7 VIII 1791 r.). Por. też Z. Anu sik, Dyplomacja..., s. 433-434; i d e m, France..., s. 391-392. 
wie. Gustaw III przekazał też Stedingkowi wiadomość, że hrabia d’Artois skłonił w Pillnitz cesarza i króla pruskiego do wydania wyraźnej deklaracji, iż podejmą oni działania w sprawach francuskich. Żąając od swojego ambasadora uzyskania jasnej odpowiedzi dworu petersburskiego, król przekonywał go równocześnie, że 30 tys. żołnierzy wysadzonych w Normandii wystarczy do odniesienia zwycięstwa nad zwolennikami rewolucji we Francji. W tym samym liście Gustaw III powiadomił też Stedingka, że podjął starania o uzyskanie subsydiów hiszpańskich majacych umożliwić mu sfinansowanie planowanej wyprawy do Francji ${ }^{59}$.

Kilka dni później, 20 września 1791 r., do Sztokholmu przyjechał baron Jean François d'Escars, wysłany z Pillnitz przez hrabiego d'Artois, który powierzył mu obowiązki przedstawiciela książąt u boku Gustawa III. Król szwedzki bez wahania zgodził się na oficjalna akredytację barona na swoim dworze. Nowy dyplomata francuski złożył zaś Gustawowi III szczegółowe sprawozdanie z przebiegu rozmów i rezultatów konferencji w Pillnitz ${ }^{60}$. W początkach października Gustaw III otrzymał kolejny list od braci Ludwika XVI. Ludwik hrabia Prowansji i Karol hrabia d'Artois informowali w nim króla, że wysłali do Paryża deklarację ogłoszoną w Pillnitz, a swój list do władcy Francji opublikowali w formie manifestu. Apelowali też o pośpiech w działaniach, gdyż ich wrogowie mieli robić wszystko, aby podważyć tron ich brata i zniszczyć francuską monarchię. Zdaniem książąt trzeba więc było utrudnić ich przygotowania do obrony, dodać otuchy wiernym poddanym króla Francji i powiadomić Europę o prawdziwych uczuciach wszystkich władców. Nie szczędząc komplementów pod adresem Gustawa III, bracia Ludwika XVI przekonywali go, że ze względu na dobro wspólnej sprawy i oczekiwania mieszkańców Francji musieli ujawnić opinii publicznej znane im zamiary mocarstw i składane przez nie obietnice. Ksiażęta byli także pewni tego, że chociaż Szwecja jest tak bardzo oddalona, Gustaw III zdoła pokonać wszelkie trudności i pośpieszy na pomoc królowi i narodowi, który zawsze był wiernym

59 Por. Gustaw III do C. v. Stedingka, Drottningholm 13 IX 1791, RA, Muscovitica vol. 489. W sprawie ówczesnych planów króla por. też C.G. Nor din, op. cit., s. 177 (zapiska z 31 VIII 1791 r.).

${ }^{60}$ Por. Karol hrabia d'Artois do Gustawa III, Drezno 29 VIII 1791, RA, Gallica vol. 521. Por. też A. Söderhjelm, Sverige..., s. 275-276; oraz N. Åkeson, op. cit., Bd I, s. 138. Oboje datuja przyjazd d'Escarsa do Sztokholmu na 21 IX 1791 r. Według dzienników C.G. Nordina poseł książąt przyjechał jednak do stolicy Szwecji w dniu 20 IX. Por. ide m, op. cit., s. 182-183. 
przyjacielem Szwecji ${ }^{61}$. Wypada sądzić, że król Szwecji nie we wszystkim zgadzał się $z$ przywódcami francuskiej emigracji. Nie miał jednak ani czasu, ani ochoty na jakakolwiek polemikę $z$ książętami. Niemal w tym samym czasie do Sztokholmu dotarła bowiem wiadomość o zaprzysiężeniu przez Ludwika XVI nowej konstytucji francuskiej. Gustaw III był zaskoczony i wstrząśnięty tym wydarzeniem. Wydawało się bowiem, że może ono doprowadzić do przekreślenia planów zbrojnej interwencji we Francji62.

Podobnie patrzył na to zagadnienie reprezentant dworu francuskiego w Sztokholmie, kawaler Jean de Gaussen, który już 30 września $1791 \mathrm{r}$. pisal do swojego ministra spraw zagranicznych, że: „akceptacja konstytucji przez króla powinna bez wątpienia doprowadzić do zaniechania nie tylko przygotowań wojennych czynionych przez Jego Wysokość, ale również przez wszystkie inne mocarstwa, które chciałyby mieszać się do naszych spraw". W tym samym liście Gaussen ostrzegał jednak Montmorina, że Gustaw III nie zmienił wcale swojego dotychczasowego sposobu myślenia, oficjalnie oświadczajacc, że Ludwik XVI nie jest naprawdę wolny i $z$ tego powodu nie ma on zamiaru uznawać francuskiej konstytucji ${ }^{63}$. Dosłownie kilka dni później Gaussen wszedł w posiadanie listu Ludwika XVI z dnia 19 września 1791 r., w którym władca Francji oficjalnie poinformował Gustawa III o zaprzysiężeniu przez siebie nowej konstytucji ${ }^{64}$. Z listem królewskim do Sztokholmu nadeszła obszerna depesza Armanda Marca de Montmorina. Francuski minister spraw zagranicznych pisał w niej do kawalera de Gaussen: „Wie pan zapewne, że rozchodzą się wieści, jakoby król Szwecji chciał wmieszać się w nasze wewnętrzne sprawy. Jakkolwiek jesteśmy dalecy od przywiazywania wagi do tych plotek, to są one wystarczające, żeby król przedstawił władcy Szwecji swój sposób myślenia tak w sprawie obecnej sytuacji we Francji, jak i w kwestii swoich zamiarów dotyczacych przywrócenia trwałego spokoju. Po tym, jak król zatwierdził akt konstytucji, musi on być uznany nie tylko za cieszącego się pełną wolnością, ale i dysponującego pełnią władzy przyznanej mu przez konstytucję. W tej sytuacji

${ }^{61}$ Por. Ludwik hrabia Prowansji i Karol hrabia d'Artois do Gustawa III, Schönbornlust koło Koblencji 14 IX 1791, RA, Gallica vol. 521. Por. też Z. Anusik, Dyplomacja..., s. 435; idem, France..., s. 393.

62 Por. A. Sö d e rhjelm, Sverige..., s. 276; Z. A nu sik, Dyplomacja..., s. 435-436.

${ }^{63}$ Por. J. de Gaussen do A.M. de Montmorina, Sztokholm 30 IX 1791, cyt. według A. Söderhjelm, Sverige..., s. 277.

${ }^{64}$ Por. Ludwik XVI do Gustawa III, Paryż 19 IX 1791, RA, Gallica vol. 520. 
jakiekolwiek próby pomszczenia znieważonej jakoby godności królewskiej są bezzasadne i moga spowodować trudne do przewidzenia następstwa. Taki jest sposób myślenia króla i poleca on wyjaśnić wszystkie te kwestie Francowi. Król zapomniał już o wszystkim, co wydarzyło się w ciagu ostatnich dwóch lat, i dawne urazy nie będą rzutować na jego postępowanie. Jego jedynym celem jest zapewnienie spokoju wewnętrznego i zewnętrznego. Nieco mniej lub nieco więcej władzy nie stanowi o jego osobistym szczęściu, gdyż konstytucja, która zaakceptował, zapewnia tę władzę narodowi francuskiemu. I jeśli obywatele wszystkich klas skupiaja się wokół niej, nie będzie on niczego żałował, ani też nie będzie sobie życzył żadnych zmian w tym względzie. Decyzja o akceptacji została podjęta po namyśle i ze względu na swoją użyteczność wraz z silnym postanowieniem dochowania wierności złożonej przysiędze. W tej sytuacji król musi zadbać o to, aby jego królestwo nie było niepokojone $z$ zagranicy. Ma więc pan zapewnić swoich rozmówców, że wszelkie próby podważenia konstytucji przez mocarstwa zagraniczne sprawią królowi nieskończenie wielka przykrość. Rozchodzą się bowiem niestety pogłoski, że cesarz i król pruski chcieliby sprowokować wszystkich władców europejskich do wystapienia przeciwko narodowi francuskiemu. Że wszyscy władcy zamierzaja wyruszyć na pomoc królowi i że cała Europa zamierza sprzymierzyć się przeciwko suwerennemu narodowi po to, aby narzucić mu zmianę jego formy rządu. Wszystko to wydaje się tak dziwaczne, tak przeciwne poczuciu prawa narodów i rozwagi politycznej, że nie ma tu nic więcej do dodania. Jednak ponieważ doświadczenie uczy, zwłaszcza w ostatnich czasach, że rzeczy nawet najbardziej niewiarygodne moga się doczekać swojej realizacji, jesteśmy zmuszeni zwrócić baczną uwage na to, co tak otwarcie mówi się na ten temat. Król jest bardzo daleki od tego, aby sądzić, że władca Szwecji weźmie udział w przedsięwzięciu tak przeciwnym prawom narodów. Gdyby jednak się na to zdecydował, powinien pan wyraźnie zaznaczyć w szwedzkim ministerium, że wszelkie kroki podjęte w celu zmiany porządku rzeczy, który ustanowił naród francuski i który został zaakceptowany przez króla, będa uznane za zamach na niepodległość Francji. Nawet jeśli umniejszono zakres władzy królewskiej, Ludwik XVI nie będzie występował przeciwko woli narodu i narażał królestwa na podwójne nieszczęście wojny domowej i wojny zewnętrznej. To sa motywy działania króla, które przedstawia się na wszystkich dworach, żeby odwieść je od mieszania 
się w wewnętrzne sprawy Francji. Jego Wysokość ma nadzieję, że jego argumenty przyniosa pożądany skutek. W tym tonie ma pan rozmawiać ze szwedzkim ministerium i ma pan prosić, aby sprawa ta została przedstawiona również królowi. Ten władca powinien uznać, że król, który tak wiele poświęcił dla utrzymania spokoju swojego państwa, nie zaniedba niczego, aby odwieść go od podejmowania bezużytecznych zamierzeń" ${ }^{65}$.

Warto w tym miejscu odnotować znamienny fakt, że 7 października 1791 r. francuski chargé d'affaires postanowił przekazać kopię powyższego listu szwedzkiemu sekretarzowi stanu - Ulricowi Gustafowi Francowi. Jean de Gaussen przesłał też na ręce Franca list Ludwika XVI adresowany do Gustawa III wraz z egzemplarzem nowej konstytucji francuskiej. Następnego dnia sekretarz stanu odesłał mu jednak nienaruszony pakiet, odmawiajac mu jednocześnie prawa do reprezentowania dworu francuskiego w Sztokholmie. Od chwili zatrzymania Ludwika XVI w Varennes Szwecja i Rosja nie uznawały bowiem de facto misji francuskich w swoich stolicach. Teraz nastapiło więc jedynie formalne potwierdzenie tego stanu rzeczy. Już 8 października 1791 r. Franc poinformował Curta von Stedingka o odmowie przyjęcia pakietu korespondencji przesłanej mu przez Gaussena, stwierdzając przy tej okazji, że zdaniem Gustawa III nie ma żadnych misji francuskich ani w Szwecji, ani w Rosji. W biuletynie pisanym w dniu 11 października do Hansa Axela von Fersena sekretarz stanu zawiadomił go $z$ kolei, że od tej pory Gaussen będzie traktowany jak osoba prywatna i nie będzie zapraszany na konferencje ministerialne. W tej sytuacji dwór francuski podją ostentacyjne przygotowania do odwołania swojego reprezentanta ze Sztokholmu, nie śpieszac się jednak $z$ wydaniem mu rozkazów, aby faktycznie wracał do Francji ${ }^{66}$.

Cofnięcie akredytacji dotychczasowemu reprezentantowi dworu paryskiego wynikało niewątpliwie $z$ przyjęcia w Sztokholmie posła przysłanego przez francuskich emigrantów. Na twarda postawę Gustawa III w tej sprawie wpływała jednak również świadomość tego, że jego działania znajda pełna akceptację w oczach Katarzyny II. Już w połowie września 1791 r. jego negocjatorom udało się

${ }^{65}$ Por. A.M. de Montmorin do J. de Gaussena, Paryż 19 IX 1791 (kopia), RA, Gallica vol. 533. Por. też Z. Anu sik, Dyplomacja..., s. 436-437; idem, France..., s. 393-394.

66 Por. A. Söd e rhj elm, Sverige..., s. 274, 278-279; N. Åk e s o n, op. cit., s. 137. Por. też U.G. Franc do J. de Gaussena, Drottningholm 8 X 1791 (kopia), RA, Muscovitica vol. 489. 
bowiem uzgodnić warunki przyszłego traktatu $z$ dworem petersburskim. Na mocy zawartego wówczas porozumienia Gustaw III miał otrzymywać 300 tys. rubli rocznego subsydium. Zwlekał jednak $z$ podpisaniem ostatecznej wersji układu sojuszniczego, licząc na zwiększenie wysokości wypłat rosyjskich do 500 tys. rubli rocznie. O wszystkich tych sprawach król informował szczegółowo Curta von Stedingka w liście $z$ dnia 7 października 1791 r. ${ }^{67}$ Kilka dni później, 11 października, do Drottningholmu nadszedł list od barona de Breteuil. Zaufany pełnomocnik Ludwika XVI na emigracji pisał w nim, że Gustaw III powinien być zadowolony ze swoich zabiegów o zawarcie traktatu subsydiowego $z$ dworem madryckim. Książę de La Vauguyon zapewnił go bowiem, że król Hiszpanii wydał stosowne dyspozycje w tej sprawie. Breteuil prosił jednak króla o przesłanie dokładniejszych informacji na ten temat. Baron zapewniał też władcę Szwecji, że wierzy w to, że już niedługo skończą się wszystkie nieszczęścia króla Francji i jego królestwa, jeśli tylko wszystkie mocarstwa, które interesują się tą sprawą, będą działać tak konsekwentnie i tak zdecydowanie, jak Gustaw III. Breteuil pocieszał się także myślą o tym, że zapał króla Szwecji i cesarzowej Rosji doprowadzi do pokonania wszystkich trudności i zburzy zimną kalkulację polityczną innych dworów. Również on przewidywał jednak, że myśl o interwencji we Francji trzeba będzie odłożyć do wiosny przyszłego roku ${ }^{68}$.

Już 14 października Gustaw III odpowiedział na list Breteuila. Poinformował w nim barona, że właśnie cofnął akredytację dla chargé d'affaires Francji w Sztokholmie, gdyż uważa, że Ludwik XVI nie dysponuje prawdziwa swoboda działania. Skarżąc się na to, że cesarz postanowił wykorzystać przyjęcie konstytucji przez króla Francji do ostudzenia gorliwości i zapału króla Prus, Gustaw III zastanawiał się równocześnie nad motywami kierującymi postępowaniem Ludwika XVI. Odpierał jednocześnie oskarżenia francuskiego dworu pod adresem książąt, uważając je za niesłuszne i niesłużące wspólnej sprawie. Informując barona o bliskiej finalizacji rozmów z Rosja i stwierdzając, że na wiosnę powinien być gotowy do działania, Gustaw III ubolewał jednak nad tym, że ta zwłoka może

${ }^{67}$ Por. N. Åkeson, op. cit., Bd I, s. 137; Z. Anusik, Dyplomacja..., s. 438; id e m, France..., s. 395.

68 Por. L.A. de Breteuil do Gustawa III, Bruksela 25 IX 1791, RA, Gallica vol. 524. Ten sam list por. też M. Price, Louis XVI and Gustavus III: Secret Diplomacy and Counter-Revolution 1791-1792, "The Historical Journal” 1999, vol. XLII, No. 2, s. 456; oraz Z. Anu sik, Dyplomacja..., s. 438; id e m, France..., s. 395-396. 
dać buntownikom czas na przygotowanie się do obrony. Był wyraźnie niezadowolony, że odkłada się do wiosny to, co powinno być zrobione jesienią. W dalszej części tego listu król pisał, że ponieważ Hans Axel von Fersen niczego nie osiagnał na dworze cesarskim, odsyła go do Brukseli, gdzie będzie rezydował przez zimę. Zapowiadał jednocześnie, że baron Carl Gustaf Oxenstierna zostanie w najbliższym czasie mianowany przez niego ministrem u boku książąt. Zdaniem króla to Monsieur reprezentował bowiem wówczas prawdziwe władze francuskie. Król pozwolił sobie przy tej okazji na wyrażenie nadziei, że przykład dany przez niego i przez Katarzynę II spowoduje, że inni władcy też wyślą swoich posłów do książąt. Gustaw III radził też Breteuilowi, aby Ludwik XVI zwrócił się o pomoc do króla Prus, który jest dobrze usposobiony, ale nie chce działać wbrew woli króla Francji. Proponował też swoje pośrednictwo w rozmowach $z$ dworem berlińskim. Na zakończenie swojego listu władca Szwecji wytoczył szereg zarzutów pod adresem króla Francji, oskarżając go o zaprzepaszczenie interesów jego korony i jego rodziny. Atak na Ludwika XVI okazał się jedynie wstępem do stwierdzenia, że ze względu na postępowanie tego władcy Gustaw III postanowił wspierać nie jego, ale jego braci. Król nie omieszkał też zaznaczyć, że jego poglądy w tej kwestii sa w pełni akceptowane przez Katarzynę II $^{69}$.

Nie trzeba dodawać, że list tej treści musiał w istotny sposób wpłynąć na ochłodzenie stosunków między dworem sztokholmskim a zaufanym doradca króla Francji. W pisanym tego samego dnia liście do Curta von Stedingka Gustaw III zaznaczył, że jego dalsza polityka wobec Francji jest uzależniona od podpisania traktatu z Rosja. Z listu królewskiego wynikało także, że szwedzkie zabiegi w tej sprawie były wspierane w Petersburgu przez wysłannika książąt, hrabiego Valentina Esterhazy'ego. I aczkolwiek poparcie ze strony francuskich emigrantów nie miało w sumie większego znaczenia, to sprawiło Gustawowi III niekłamana przyjemność i przyśpieszyło jego decyzję o wysłaniu szwedzkiego posła do Koblencji ${ }^{70}$.

69 Por. Gustaw III do L.A. de Breteuila, pałacyk Haga 14 X 1791, cyt. według N. Åke s o n, op. cit., Bd II, s. 150, 224-227. Por. też M. Price, op. cit., s. 456-458. Warto w tym miejscu zaznaczyć, że już następnego dnia, 15 X 1791 r. Gustaw III wysłał do swojego posła na dworze berlińskim Christiana Ehrenfrieda von Carisiena depeszę $z$ rozkazem uzyskania jednoznacznej deklaracji Fryderyka Wilhelma II w sprawach francuskich. Por. N. Åkes o n, op. cit., Bd II, s. 145; Z. Anu sik, Dyplomacja..., s. 438-439.

${ }^{70}$ Por. Gustaw III do C. v. Stedingka, Drottningholm 14 X 1791, RA, Muscovitica vol. 489. 
W tym samym dniu, w którym Gustaw III napisał cytowane wyżej listy, baron Jean François d'Escars złożył na ręce króla oficjalną notę dyplomatyczną. Celem tego wystapienia było nakłonienie władcy Szwecji do jak najszybszego sfinalizowania rozmów sojuszniczych $z$ dworem petersburskim. Wysłannik książąt rozpoczął od przypomnienia podstawowych faktów. Pisał, że powszechnie wiadomo, że Gustaw III szykuje do interwencji we Francji swoją armię i flotę, oczekując równocześnie na zawarcie odpowiednich traktatów sojuszniczych. Potrzebuje jednak subsydiów, których źródłem moga być jedynie Rosja i Hiszpania. Oba te państwa nie zaczna jednak płacić, zanim nie podpisza ze Szwecją odpowiednich traktatów. Król żąda od Rosji 500 tys. rubli rocznego subsydium. Jej pełnomocnik oferuje jednak tylko 300 tys. rubli, co odwleka zawarcie traktatu. Tymczasem Hiszpania jest skłonna związać się aliansem z państwami Północy. Czeka jednak na podpisanie sojuszu szwedzko-rosyjskiego. Zawarcie tego układu zapewni więc Gustawowi III zarówno subsydia rosyjskie, jak i hiszpańskie. Dalej d'Escars pisał, że ponieważ cesarz zawiesił swoje działania do końca zimy, odwleka to udział Austrii, Prus i Rzeszy w dziele ratowania Francji. Tylko Gustaw i Katarzyna stanowią więc pozytywny przykład dla całej Europy, a jedyne, co ich dzieli, to określenie wysokości rosyjskich subsydiów. Wysłannik książąt prosił więc Gustawa III, aby zaakceptował propozycje rosyjskie i zgodził się przyjąc subsydia w wysokości 300 tys. rubli. Wydatki poniesione przez Szwecję w dziele ratowania Francji z pewnością zostaną bowiem w przyszłości zrekompensowane przez Rosję. Nie ulega również wątpliwości, że Gustaw III uzyska subsydia od Hiszpanii, kiedy ta sprzymierzy się z mocarstwami Północy. Można będzie wtedy określić satysfakcjonujacca dla króla Szwecji wysokość płaconych przez nią subsydiów. List króla Hiszpanii, który Gustaw III zechciał pokazać d'Escarsowi, jest w tym względzie jasny i jednoznaczny. Francuski dyplomata gorąco namawiał też króla do zawarcia potrójnego aliansu, którego przyszłych uczestników łączyć miały wspólne poglądy i wspólna nienawiść do hydry demokracji. Jego zdaniem działania sprzymierzonych dworów miały być przykładem i zachętą dla reszty Europy. D’Escars zapewniał też Gustawa III, że wszystkie jego wysiłki zostaną wynagrodzone przez Ludwika XVI, który nie będzie się wahał $z$ odnowieniem dawnych układów ze Szwecja na tych samych albo na korzystniejszych dla niej warunkach. Obmyślenie nagrody dla Gustawa III z pewnością będzie jednym z pierwszych 
życzeń braci władcy Francji. Sojusz króla Szwecji z cesarzową będzie więc pierwszym ogniwem w łańcuchu wydarzeń jednakowo ważnych dla interesów i sławy Gustawa III. Zachęcając króla do zawarcia układu $z$ Rosja, baron zdecydowanie odradzał natomiast podpisywanie jakichkolwiek traktatów $z$ Anglia, obojętną wobec losów Ludwika XVI i wrogą wobec Francji. W końcowej części wystąpienia d'Escarsa znalazł się również następujący wywód: „Wasza Królewska Mość zbawi Francję. Rebelianci i buntownicy już drżą na dźwięk imienia Gustawa. Wierna Francja pokłada wszystkie swoje nadzieje w tym imieniu. Czekaja na niego Ludwik XVI, zjednoczony bez watpienia w sekrecie $z$ poglądami swoich dostojnych braci, $z$ domem de Condé, $z$ ogromem szlachty, $z$ liczną częścią wojska i dobrych obywateli. Już wybrzeża Normandii i Bretanii sa pokryte ludźmi oczekującymi przybycia floty Waszej Wysokości. Już tysiące szlachty i wiernych żołnierzy czekaja, by zebrać się pod Waszymi sztandarami. Już jesteś wzywany jako anioł stróż Francji i jako restaurator jej tronu. Szykowane sa liczne wawrzyny na Twoje przybycie". Na zakończenie d'Escars przypomniał jeszcze, że zarówno Monsieur, jak i hrabia d'Artois bardzo życzyliby sobie szybkiego zawarcia sojuszu szwedzko-rosyjskiego. Obiecał również napisać do hrabiego Esterhazy'ego, aby zrobił wszystko, co w jego mocy, by skłonić cesarzową do przyjęcia warunków zaproponowanych przez króla szwedzkiego ${ }^{71}$. Interesujace wystapienie dyplomaty reprezentujacego interesy francuskich emigrantów okazało się jednak w sumie nieco spóźnione i nie wpłynęło w jakikolwiek sposób na dalsze postępowanie Gustawa III. Rokowania szwedzko-rosyjskie zbliżały się bowiem do pomyślnego końca.

Dnia 19 października 1791 r. negocjatorzy szwedzcy: Carl Axel Wachtmeister, Evert Taube, Gustaf Mauritz Armfelt, Ulric Gustaf Franc i Anders Håkansson oraz ambasador rosyjski w Sztokholmie Otto Magnus von Stackelberg złożyli swoje podpisy na tekście traktatu drottningholmskiego łączącego sojuszem Rosję i Szwecję. Zgodnie $z$ brzmieniem tego układu zakładano ścisła współpracę posłów obu stron przy dworach zagranicznych. W wypadku ataku ze strony innego państwa przewidywano najpierw bona officia, a potem wysłanie posiłków zbrojnych. Szwecja miała dostarczyć w takim przypadku 8 tys. piechoty, 2 tys. kawalerii, 6 okrętów linio-

${ }^{71}$ Por. Nota J.F. d'Escarsa wręczona Gustawowi III, Sztokholm 14 X 1791, RA, Gallica vol. 533. Por. też Z. Anu sik, Dyplomacja..., s. 439-441; idem, France..., s. 397-398. 
wych i 2 fregaty. Ze swej strony Rosja powinna wysłać na pomoc Szwedom 12 tys. piechoty, 4 tys. kawalerii, 9 okrętów liniowych i 3 fregaty. Gdyby stypulowane posiłki okazały się niewystarczajace, druga strona miała się udać na pomoc sojusznikowi $z$ większymi siłami, jeśli jej własna sytuacja pozwalałaby na takie rozwiazanie. Traktat przewidywał również, że oba dwory nie będa w przyszłości osobno i bez konsultacji zawierać żadnego pokoju ani też innego układu. Od 1 stycznia 1793 r. kupcy obu stron mieli korzystać $z$ takich samych praw i przywilejów, jak obywatele sprzymierzonych mocarstw. Podpisany w dniu 19 października układ miał obowiąywać przez osiem lat i mógł zostać przedłużony na sześć miesięcy przed upływem terminu jego ważności. Do traktatu drottningholmskiego załączono dwa artykuły odrębne i tajne. Pierwszy $z$ nich przewidywał, że w razie wybuchu wojny rosyjsko-tureckiej Szwecja nie będzie zobowiązana do przysłania Rosji posiłków ani $\mathrm{w}$ postaci wojska, ani floty, ani pieniędzy. Artykuł drugi stanowił, że przez cały czas obowiązywania traktatu Szwecja będzie otrzymywała subsydia rosyjskie w wysokości 300 tys. rubli rocznie. Pierwsza rata - 150 tys. rubli miała zostać wypłacona już po wymianie not ratyfikacyjnych. Następnych 150 tys. rubli miało wpłynać do kasy Gustawa III w sześć miesięcy później. Kolejne wypłaty miały następować co sześć miesięcy przez osiem lat. Jednocześnie król Szwecji zobowiązał się doprowadzić do odpowiedniego stanu swoje siły morskie i lądowe. Obie strony zobowiązały się też nie wchodzić w żadne układy sprzeczne $z$ brzmieniem zawartego traktatu ${ }^{72}$. Gustaw III miał więc teraz wszelkie powody do zadowolenia. Mogło się bowiem wydawać, że oto zniknęła ostatnia przeszkoda na drodze do upragnionej interwencji w obronie Ludwika XVI i pomszczenia poniżonej godności wszystkich innych królów.

Podpisanie traktatu drottningholmskiego stanowiło istotny przełom w dziejach polityki szwedzkiej wobec Francji. Gustaw III był bowiem przekonany, że $z$ pomoca Rosji uda mu się wreszcie przekonać innych władców o konieczności interwencji na rzecz Ludwika XVI. Już 28 października 1791 r. król Szwecji napisał do Katarzyny II, wyrażając radość ze sfinalizowania rokowań sojuszniczych i informując ją o swoich ostatnich posunięciach. W liście tym

${ }^{72}$ Por. Kopia szwedzko-rosyjskiego traktatu sojuszniczego podpisanego w Drottningholmie w dniu 19 X 1791 r., RA, Muscovitica vol. 489. Por. też C.T. Od hner, Gustaf III och Katarina II efter..., s. 50-54; A. Sö de rhjelm, Sverige..., s. 273 (tu błędna data - 14 zamiast 19 X); Z. Anusik, Dyplomacja..., s. 441-442; idem, France..., s. 398-399. 
pisał, że wysłał Hansa Axela von Fersena do Brukseli, rozkazując mu podjęcie działań na rzecz przywrócenia dawnych prerogatyw koronie francuskiej. Jednocześnie zapewniał jednak cesarzową, że w instrukcjach jego posła nie znalazły się żadne sformułowania skierowane przeciwko francuskim książętom. Przy tej samej okazji Gustaw III przypomniał swój pomysł, aby Monsieur przyjął natychmiast tytuł regenta. Pochwalił też akredytowanie przez cesarzowa Nikołaja P. Rumiancewa u boku książąt w Koblencji oraz wysłanie przez nią osobistych listów do Leopolda II i do Fryderyka Wilhelma II. Uważał bowiem, że wszystkie te posunięcia władczyni Rosji powinny pomóc ich wspólnej sprawie. Ze swojej strony król napisał z kolei do Karola IV, starając się wciągnąć Hiszpanię do akcji przeciwko francuskim buntownikom. W dalszej części swojego listu Gustaw III pisał, że na wiosnę chciałby być gotów do działania. Namawiał też Katarzynę II do ogłoszenia deklaracji, że zamierza ona podjać akcję na rzecz Ludwika XVI, co powinno zmusić innych władców do naśladowania przykładu dworu petersburskiego. Starając się uzgodnić $z$ cesarzową postępowanie w sprawie odpowiedzi na list Ludwika XVI $z$ notyfikacja przyjęcia przez niego nowej konstytucji, król wystąpił z propozycją odwołania posła rosyjskiego $z$ Paryża. Zapowiadał też wysłanie własnego posła do Koblencji. Swój list do carowej Gustaw III zakończył wyrażeniem obawy o bezpieczeństwo ministrów cudzoziemskich akredytowanych w stolicy Francji (ani w Sztokholmie, ani w Petersburgu nie było bowiem ministrów francuskich, wobec których można by ewentualnie zastosować represalia) oraz obietnica konsultowania $z$ Katarzyna II wszystkich swoich dalszych posunięć ${ }^{73}$. Do listu do cesarzowej Gustaw III załączył też memorandum w sprawie lądowania w Normandii. Znalazła się w nim również mapa sporządzona przez kapitana Fieandta $z$ zaznaczeniem drogi z Hawru do Paryża. Do działań w Normandii król zamierzał użyć: 11 okrętów liniowych, 7 fregat, 3 brygów, 2 kutrów, 25 szalup zaopatrzonych w jedno działo 24 funtowe i 40 łodzi desantowych, z których każda mogła pomieścić 100 ludzi. Flota miała przerzucić do Francji 16 tys. piechoty i 2400 kawalerii. $Z$ tymi siłami Gustaw III planował zajęcie Paryża i dokonanie restauracji starego porządku we Francji ${ }^{74}$.

${ }^{73}$ Por. Gustaw III do Katarzyny II, Sztokholm 28 X 1791, N. Åke s o n, op. cit., Bd II, s. 227-230; Z. Anu sik, Dyplomacja..., s. 538; id e m, France..., s. 495-496.

${ }^{74}$ Pełny tekst tego memorandum por. L. Manderström, Om Gustaf III:s yttre politik under de två senaste åren af dess regering, Stockholm 1859, Bilaga $Q$, 
W poczatkach listopada $1791 \mathrm{r}$. Gustaw III napisał do Christiana Ehrenfrieda von Carisiena w Berlinie oraz do Johana Fredrika von Nolckena w Wiedniu, nakazując im podjęcie starań o pozyskanie obu dworów na rzecz koncepcji współdziałania wszystkich monarchów europejskich w sprawie Francji. O ile jednak pozyskanie Fryderyka Wilhelma II wydawało mu się możliwe do osiągnięcia, to w kwestii współpracy z Leopoldem II był bardziej sceptyczny. W tym samym czasie (4 listopada) Gustaw III pisał bowiem do Curta von Stedingka, że wieści $z$ Madrytu napawaja go optymizmem i każą mu wierzyć w to, że Hiszpania zdecyduje się czynnie włączyć w dzieło restauracji dawnego porzadku we Francji. W stosunku do cesarza król w dalszym ciagu był jednak bardzo nieufny i podejrzewał go o niechęć wobec wysiłków podejmowanych przez inne dwory. Najlepszym dowodem na potwierdzenie tych obaw miało być złe przyjęcie w Wiedniu wiadomości o akredytowaniu Rumiancewa i Oxenstierny u boku książąt w Koblencji ${ }^{75}$. Kilkanaście dni później Gustaw III przedstawił Katarzynie II plan lądowania wojsk szwedzkich w Normandii, przekonując ją równocześnie o konieczności współdziałania Rosji, Szwecji, Austrii, Prus, Hiszpanii i Sardynii w dziele przywracania starego porządku we Francji ${ }^{76}$. W pisanym 25 listopada 1791 r. liście do Curta von Stedingka Gustaw III zapewniał swojego ambasadora na dworze cesarzowej Rosji, że wszystko wskazuje na to, iż w najbliższym czasie Hiszpania zdecyduje się na wejście do antyfrancuskiej koalicji. Ponieważ zaś Johan Fredrik von Nolcken donosił $z$ Wiednia, że Andriej K. Razumowski, reprezentant Rosji na dworze cesarskim, jest zwolennikiem interwencji mocarstw w obronie Ludwika XVI, tego samego dnia Gustaw III napisał do swojego przedstawiciela w stolicy Austrii, aby wraz $z$ posłem rosyjskim i hiszpańskim starał się wpłynać na cesarza, żeby ten porzucił swoją neutralność i włączył się aktywnie w dzieło ratowania monarchii we Francji ${ }^{77}$.

Dnia 30 listopada $1791 \mathrm{r}$. dotarł do Drottningholmu list barona de Breteuil. Zaufany minister Ludwika XVI pisał w nim, że w dal-

s. 74; oraz N. Åkeson, op. cit., Bd I, s. 139-140. Por. też Z. Anusik, Dyplomacja..., s. 538-539; id e m, France..., s. 496.

75 Por. N. Åke s o n, op. cit., Bd II, s. 149; oraz Gustaw III do C. v. Stedingka, Drottningholm 4 XI 1791, apostille, RA, Muscovitica vol. 489.

76 Por. Gustaw III do Katarzyny II, Drottningholm 21 XI 1791, N. Åk e s o n, op. cit., Bd I, s. 140. Por. też Z. Anu si k, Dyplomacja..., s. 539; id e m, France..., s. 496-497.

77 Por. Gustaw III do C. v. Stedingka, Drottningholm 25 XI 1791, RA, Muscovitica vol. 489. Por. też N. Åke s o n, op. cit., Bd II, s. 149. 
szym ciagu oczekuje na ostateczną decyzję cesarza w sprawie sankcji władcy Francji dla nowej konstytucji. Usprawiedliwiając decyzję swojego monarchy w tej kwestii, Breteuil pisał, że Ludwik XVI trzymany jest przez buntowników w całkowitej niewiedzy co do tego, czego może się spodziewać ze strony mocarstw. W tym okrutnym położeniu, bez rady i wsparcia, uznał więc za konieczne zaprzysiężenie konstytucji po to, żeby uwierzono w jego dobrą wolę, żeby zdobyć zaufanie ludu, żeby go uspokoić i żeby zdobyć sposobność do łatwiejszego działania. Ponieważ zaś również królowa była przekonana, że w najbliższym czasie nie będzie można spodziewać się żadnych posiłków zagranicznych, Ludwik XVI podjął decyzję, że nie będzie odmawiał wydawania żądanych od niego przez buntowników deklaracji i zaręczeń oraz że będzie postępował zgodnie $z$ zasadami nowej konstytucji. Breteuil przekonywał Gustawa III, że król zdaje sobie sprawę $z$ całej okropności swojego położenia i chciałby je zmienić, ale w obecnych okolicznościach nie może niczego zrobić. $Z$ tego względu ograniczył wszystkie swoje żądania wobec cesarza do prośby o jak najszybsze zwołanie kongresu. Król poprosił Leopolda II, aby skłonił do udziału w tym kongresie inne mocarstwa, określił miejsce jego przyszłych obrad i spowodował bezzwłoczne nominowanie wszystkich delegatów. Pretekstu do zwołania kongresu miała dostarczyć sprawa Awinionu i szkód wyrządzonych w Alzacji ksiażętom niemieckim. W czasie trwania kongresu Ludwik XVI zamierzał wystapić w roli mediatora między mocarstwami a swoim ludem. W ten sposób, bez ryzyka dla siebie i dla swojej rodziny, spodziewał się znaleźć możliwość współdziałania $z$ mocarstwami $\mathrm{w}$ dziele restauracji ancien regime'u. $\mathrm{W}$ dalszej części swojego listu baron starał się przekonać Gustawa III o konieczności podporządkowania francuskich książąt woli i poglądom wyznawanym przez Ludwika XVI. Proponował też, aby król Szwecji zapośredniczył ugodę między władcą Francji a jego braćmi. $\mathrm{W}$ istocie Breteuilowi chodziło jednak o to, by dwór tuileryjski mógł potajemnie kierować poczynaniami emigrantów. Pisał bowiem, że książęta nie powinni nic wiedzieć o zawarciu porozumienia między władca Francji a królem Szwecji i powinni być przekonani, że wszelkie wskazówki odnośnie do ich postępowania pochodzą wyłącznie od Gustawa III. Uskarżając się na obojętność cesarza wobec losów francuskiej rodziny królewskiej, Breteuil obawiał się, że Leopold II odrzuci pomysł zwołania kongresu. Dlatego też namawiał Gustawa III, aby z Rosja i Prusami wywarł odpowiedni nacisk 
na cesarza, żeby skłonić go do zmiany jego dotychczasowego postępowania. Uważał także, że konieczne będzie włączenie do przyszłej ligi również Hiszpanii, której władca powinien objąć jej formalne przywództwo. Zapewniając Gustawa III, że Ludwik XVI z pewnością zrekompensuje wszystkie wydatki poniesione na jego rzecz przez skarb szwedzki, Breteuil za wszelką cenę starał się jednak odwieść króla od poparcia pomysłu obwołania regentem hrabiego Prowansji. Twierdził bowiem, że jest mu przeciwny zarówno Ludwik XVI, jak i król Hiszpanii oraz cesarz, którzy nigdy nie pozwolą na wprowadzenie go w życie. Na zakończenie Breteuil wyraził życzenie, aby król Szwecji i cesarzowa Rosji podzielili zapatrywania innych dworów na tę kwestię i cofnęli swoje poparcie dla zabiegów książąt o ustanowienie regencji. Obiecywał też Gustawowi III, że Francja nigdy nie zapomni tego, co zrobił dla jej króla, a jej siły i zasoby zostana oddane do jego dyspozycji, jak tylko Ludwik XVI odzyska utraconą władzę ${ }^{78}$.

List barona de Breteuil bez watpienia wpłynął na dalsze postępowanie Gustawa III, aczkolwiek król nie we wszystkim zgadzał się $z$ ministrem Ludwika XVI. Pod wpływem nalegań barona zdecydował się jednak napisać do Leopolda II w sprawie pożądanego przez dwór tuileryjski kongresu. Od początku jednak władca Szwecji był przekonany, że pomysł ten nie zostanie zaaprobowany przez dwór wiedeński. $Z$ tego też powodu zdecydował się na podjęcie zabiegów o poszerzenie sojuszu drottningholmskiego przez włączenie do niego Hiszpanii. Uważał bowiem, że najlepszym sposobem przyjścia $z$ pomoca Ludwikowi XVI będzie utworzenie ligi państw europejskich z królem Hiszpanii (uznawanym w Sztokholmie za głowę domu Bourbonów) na czele. Przywództwo Karola IV miało być jednak czysto formalne. Wojskami ligi dowodzić miał bowiem osobiście Gustaw III. $Z$ tego też względu dwór sztokholmski nie lekceważył postawy Leopolda II i za wszelką cenę starał się go przekonać o konieczności czynnego wystąpienia przeciwko zbuntowanym poddanym francuskiego króla. Dyplomacja szwedzka podjęła też zabiegi o uzgodnienie $z$ cesarzem planu przyszłych operacji przeciwko Francji. Wszystkie te działania nie przynosiły

78 Por. L.A. de Breteuil do Gustawa III, Bruksela 11 XI 1791, RA, Gallica vol. 524. Ten sam list por. M. Price, op. cit., s. 458-459. Por. też Z. Anusik, Dyplomacja..., s. 539-541; idem, France..., s. 497-498; ide m, Kongres zbrojny u granic Francji. Niespełniona nadzieja kontrrewolucji spod znaku Tuileriów w latach 1791-1792, „Przegląd Nauk Historycznych” 2003, R. II, nr 2 (4), s. 111-179. 
jednak oczekiwanych rezultatów, a szwedzkie oferty w dalszym ciągu były bardzo chłodno przyjmowane na dworze wiedeńskim, który nie życzył sobie obecności wojsk Gustawa III w Europie Zachod$n{ }^{79}{ }^{79}$. Dążąc do zaostrzenia sytuacji w stosunkach $z$ rewolucyjną Francją, Gustaw III podjął też decyzję o odwołaniu z Paryża Erika Magnusa Staëla von Holsteina. Dnia 16 grudnia 1791 r. przygotowano w Sztokholmie rozkazy nakazujące ambasadorowi opuścić stolicę Francji w ciągu 14 dni od daty otrzymania tej przesyłki. Jednocześnie poinformowano Staëla, że jego dotychczasowe obowiązi przejmie Erik Bergstedt ${ }^{80}$.

W pisanym w dniu 17 grudnia 1791 r. liście do braci Ludwika XVI Gustaw III przedstawił pryncypia swojej ówczesnej polityki wobec Francji. Rozpoczał od poinformowania ksiąząt o tym, że przyjął Jeana François barona d'Escars w Sztokholmie, uznając go za jedynego reprezentanta interesów Francji na swoim dworze. Dalej stwierdził, że głównym celem jego działań będzie doprowadzenie do poszerzenia sojuszu szwedzko-rosyjskiego o Hiszpanię. Niepokój króla budziła jednak niepewna postawa tak Ludwika XVI, jak i cesarza. Ponieważ jednak pora roku nie nadawała się do podejmowania jakichkolwiek działań, Gustaw III wyrażał nadzieję, że do wiosny uda mu się przezwyciężyć wszystkie trudności. Jednocześnie wzywał swoich korespondentów do zachowania spokoju i niepodejmowania żadnych ryzykownych kroków. Twierdził bowiem, że trzeba cierpliwie poczekać do końca zimy, starając się uśpić Zgromadzenie, tak żeby nie zdążyło przygotować odpowiedniej obrony. W liście królewskim znalazła się także sugestia, aby sekretni agenci książąt starali się sprowokować Zgromadzenie do wrogich wystąpień przeciwko Rzeszy, co powinno zmusić do działania zarówno Leopolda II, jak i innych książąt niemieckich. Zapewniając braci Ludwika XVI, że Fryderyk Wilhelm II jest bardzo przychylnie usposobiony wobec ich interesów, Gustaw III żądał od nich równocześnie zachowania ścisłego sekretu, upoważniając ich do zapoznania $z$ treścią swojego listu jedynie biskupa Arras, Louisa François Conzié oraz Charles'a de Calonne. Niewatpliwie pod wpływem na-

${ }^{79}$ Por. N. Åkes on, op. cit., Bd II, s. 151, 168-170, 205; Z. Anusik, Dyplomacja..., s. 541; idem, France..., s. 498-499.

${ }^{80}$ Por. N. Åkes o n, op. cit., Bd II, s. 158-159. Kilka dni później Gustaw III poinformował o swojej decyzji C.A. v. Ehrensvärda w Madrycie oraz C. v. Stedingka w Petersburgu. W swojej depeszy pisał również, że decyzję o odwołaniu Iwana M. Simolina z Paryża podjęła także Katarzyna II. Por. Gustaw III do C.A. v. Ehrensvärda, Sztokholm 22 XII 1791 (kopia), RA, Muscovitica vol. 489. 
legań barona de Breteuil Gustaw III podjął też próbę zapośredniczenia ugody między książętami a Marią Antoniną, przekonując swoich korespondentów, że jest ona niezbędna dla ocalenia Francji. Zalecał im także rezygnację $z$ wszelkich podejmowanych na własną rękę operacji militarnych. Na zakończenie swojego listu król stwierdził, że chciałby widzieć Karola IV na czele przyszłej ligi antyfrancuskiej po to, aby pozbawić przywództwa cesarza. Król Hiszpanii obiecal już zreszta swoje wsparcie finansowe dla projektów dworu szwedzkiego, co pozwoli na wiosnę rozpoczać operacje militarne. Zdaniem Gustawa III jego flota i oddziały wojskowe były wówczas gotowe do działania, ale specjalnie spowolnił on trochę wszystkie przygotowania, aby uśpić francuskie Zgromadzenie. Król poinformował także książąt, że jak tylko Staël von Holstein wyjedzie $z$ Paryża do Copet, odeśle on do stolicy Francji nienaruszony pakiet korespondencji (zawierajacy notyfikację nowej konstytucji francuskiej) przekazany mu przez kawalera Jeana de Gaussen ${ }^{81}$.

Sytuacja króla Szwecji nie była jednak bynajmniej tak klarowna, jak starał się ją on przedstawić francuskim książętom. Gustaw III od dawna bowiem borykał się $z$ narastajacca opozycją wewnętrzna, a chroniczny brak pieniędzy skłaniał go do myśli o zwołaniu riksdagu. Król spodziewał się, że stany uchwalą nadzwyczajne podatki, które będzie można obrócić na sfinansowanie wyprawy przeciwko rewolucyjnej Francji. Obawiał się jednak poważnej opozycji ze strony przedstawicieli stanu szlacheckiego. Dlatego też zdecydował się spotkać ze stanami nie w Sztokholmie, ale na prowincji. Jego wybór padł na miejscowość Gävle. Obwieszczenie o zwołaniu zgromadzenia stanowego $\mathrm{w}$ tym miasteczku zostało opublikowane w dniu 20 grudnia 1791 r. W obawie przed rozruchami król otoczył miejsce obrad przyszłego riksdagu poważnymi siłami wojska i mieszczańsko-chłopskiej milicji. $Z$ niepokojem oczekiwał też na spotkanie $z$ reprezentacja swoich poddanych ${ }^{82}$.

Szykując się do opuszczenia stolicy, nie tracił jednak z oczu spraw francuskich. W końcu grudnia 1791 r. król Szwecji podjął kolejna próbę przekonania Fryderyka Wilhelma II o tym, że Ludwik XVI

${ }^{81}$ Por. Gustaw III do Ludwika hrabiego Prowansji i Karola hrabiego d'Artois, Sztokholm 17 XII 1791, N. Åke s o n, op. cit., Bd II, s. 236-240; Z. A nu sik, Dyplomacja..., s. 541-542; id e m, France..., s. 499-500.

${ }^{82}$ Por. A. Söderhjelm, Sverige..., s. 302; N. Åkes on, op. cit., Bd II, s. 160162; R.N. Bain, op. cit., vol. II, s. 160-161. 
nie dysponuje prawdziwa wolnością, wobec czego władcy europejscy powinni dokonać wspólnej interwencji w wewnętrzne sprawy Francji. Przy tej samej okazji pisał do króla pruskiego, że cesarz albo w ogóle nie zna, albo też przedstawia $\mathrm{w}$ fałszywym świetle prawdziwe intencje władcy Francji, który tylko pozornie współpracuje $z$ buntownikami, a $\mathrm{w}$ istocie oczekuje pomocy ze strony innych królów. W swoim następnym liście do króla pruskiego pisanym w dniu 13 stycznia 1792 r. Gustaw III stwierdził, że list Marii Antoniny powinien ostatecznie przekonać Fryderyka Wilhelma II o prawdziwym usposobieniu Ludwika XVI oczekujacego na pomoc ze strony Prus. Ostrzegał jednocześnie swojego korespondenta przed wysłanym do Berlina hrabia Louis'em de Ségur, określając go jako niewdzięcznika, który jako jeden $z$ pierwszych zdeklarował się przeciwko parze królewskiej. Wzywając Fryderyka Wilhelma II, aby wystapił w obronie króla Francji w imię solidarności wszystkich władców, zapewniał go równocześnie, że został upoważniony przez Ludwika XVI do występowania w jego imieniu zarówno wobec dworu berlińskiego, jak i wobec innych dworów, które zamierzał wciągnąc do akcji ratowania francuskiej monarchii ${ }^{83}$.

W połowie stycznia 1792 r. Gustaw III wydawał się jednak mocno zniechęcony trudnościami, na jakie napotykał na swojej drodze do sformowania ligi antyfrancuskiej. Irytowała go zarówno słabość i niekonsekwencja Ludwika XVI, jak i postawa pozostałych dworów europejskich. W tym samym czasie król pisał bowiem do Everta Taubego: „Niestety! Jakże słabemu władcy chciałbym przyjść $z$ pomocą! Nie mówię nic więcej w obawie, żeby nie powiedzieć zbyt dużo. Gdyby nie to, że nigdy w życiu nie wycofałem się ze swoich wcześniejszych zamierzeń i gdyby nie wzgląd na moje związki $z$ cesarzowa, byłbym skłonny porzucić cała tę sprawę i tych małodusznych władców, którzy nie wiedza, czy mają umrzeć, czy też się sprzymierzyć" 84 . Wydaje się jednak, że powodem złego nastroju króla mogły być także trudności, jakie piętrzyła przed nim opozycja wewnętrzna. Dnia 13 stycznia 1792 r. kawaler Jean de

${ }^{83}$ Por. Gustaw III do Fryderyka Wilhelma II, Sztokholm 23 XII 1791 i 13 I 1792, N. Åke s o n, op. cit., Bd II, s. 157, 240-242. Warto również zwrócić w tym miejscu uwagę na to, że 15 I 1792 r. Gustaw III wysłał rozkazy do C.E. v. Carisiena, nakazując mu podjąć starania o wciagnięcie dworu berlińskiego do wspólnej akcji mocarstw przeciwko rewolucyjnej Francji. Por. ibidem, s. 196. Por. też Z. A n u sik, Dyplomacja..., s. 543; id e m, France..., s. 500-501.

${ }^{84}$ Por. Gustaw III do E. Taubego, Sztokholm 13 I 1792, RA, Stafsundsarkivet, Evert Taubes Samling. vol. I. 
Gaussen pisał bowiem do swojego ministra spraw zagranicznych Antoine'a Delessarta: „Naród szwedzki jest, ogólnie rzecz biorąc, bardzo przeciwny pomysłowi króla, który zamierza domagać się od niego pieniędzy po to, aby wyprawić się do dalekich krajów i maszerować tam na czele swoich oddziałów, wdając się w przedsięwzięcie, które niechybnie doprowadzi do wciągnięcia Szwecji w otchłań takich nieszczęść, $z$ których nigdy nie będzie się mogła wydobyć". Również w swoich następnych styczniowych depeszach francuski chargé d'affaires w Sztokholmie pisał o problemach Gustawa III ze zdobyciem potrzebnych mu pieniędzy. Ostrzegał jednak swojego ministra, że jeśli tylko król zdobędzie odpowiednie środki finansowe, $z$ pewnością przeznaczy je na realizację swoich wrogich zamiarów wobec Francji ${ }^{85}$.

W połowie stycznia 1792 r. do rak Gustawa III trafiły dwa listy, które pod koniec grudnia 1791 r. napisali do niego Ludwik hrabia Prowansji i Karol hrabia d'Artois. W pierwszym $z$ nich bracia Ludwika XVI skarżyli się na lekceważenie ich problemów przez cesarza zaczynającego powoli wierzyć w to, że będzie dyrygował postępowaniem wszystkich gabinetów europejskich. Niechęć Leopolda II nie przerażała jednak bynajmniej obu książąt, którzy byli przekonani, że Gustaw III, Katarzyna II oraz królowie Hiszpanii i Neapolu wkrótce zdołaja zjednoczyć wszystkich prawdziwych przyjaciół Francji, co doprowadzi do usunięcia wszelkich przeszkód na drodze do triumfu wspólnej sprawy wszystkich władców. W tym samym liście bracia Ludwika XVI zapewniali króla Szwecji, że przez barona d'Escars będa go informować o wszystkich swoich planach i projektach. Poinformowali go również o rozpoczęciu przygotowań do zapewnienia odpowiedniego wsparcia oddziałom szwedzkim, które wyląduja na wybrzeżach Normandii. W swoim drugim liście, pisanym 24 grudnia 1791 r., Ludwik hrabia Prowansji i Karol hrabia d'Artois zapewniali $z$ kolei króla, że na bieżąco informują barona Oxenstiernę o wszystkich swoich poczynaniach, niczego przed nim nie ukrywając, gdyż wiedzą, że zawsze będą mogli liczyć na przychylność i poparcie ze strony jego władcy. Książęta prosili jednak Gustawa III, aby nie próbował osobiście kierować ich postępowaniem. Nie chcąc rozwijać tego drażliwego wątku, poprzestali na stwierdzeniu, że baron d'Escars i baron Oxenstierna sa ich zaufa-

${ }^{85}$ Por. J. de Gaussen do A. Delessarta, Sztokholm 13 I 1792, cyt. według A. Söderhjelm, Sverige..., s. 303. Por. też ibidem, s. 304; oraz Z. Anusik, Dyplomacja..., s. 544 . 
nymi powiernikami i w razie konieczności będą w stanie wyjaśnić królowi wszelkie wątpliwości w tej sprawie ${ }^{86}$.

Odpowiadając na korespondencję książąt w dniu 20 stycznia 1792 r., Gustaw III chwalił ich za opublikowanie listów do Ludwika XVI. Ostrzegal ich jednak przed publikowaniem listów do cesarza, bo to mogłoby go zrazić do ich sprawy. Zalecał też książętom podjęcie zabiegów o przyjaźń Leopolda II, którego w żadnym wypadku nie powinni lekceważyć, gdyż jest on władca mającym do dyspozycji 200 tys. żołnierzy. W nawiązaniu do prośby o powstrzymanie się od chęci kierowania wszystkimi poczynaniami książąt, Gustaw III oświadczył swoim korespondentom, że zawsze przemawiał do nich szczerze, a jeśli jego rady im się nie podobały, powinni byli mu wcześniej o tym otwarcie powiedzieć, gdyż i tak nie zmieniłoby to w niczym jego życzliwego stosunku do nich. W tym samym liście król pisał, że poczynania Zgromadzenia Prawodawczego zaostrzającego konflikt $z$ cesarzem powinny przysłużyć się ich wspólnej sprawie. Jeśli bowiem pokój zostanie zerwany, zaczna wreszcie działać książęta niemieccy. I jakkolwiek kroki te zostały podjęte przez francuskich buntowników dość późno, Gustaw III był przekonany, że nic nie zdoła zawrócić Legislatywy z raz obranej drogi. Dlatego też zdecydował się na akredytowanie barona Carla Gustafa Oxenstierny u boku elektora Trewiru i wysłał do niego rozkazy, aby starał się przekonać arcybiskupa o konieczności zachowania twardej postawy wobec żądań francuskich. Król pisał również, że wie o trudnej sytuacji francuskich emigrantów, ale prosił książąt, aby powstrzymali się od wszelkich działań, ponieważ nawet jeśli będą musieli opuścić ziemie elektora Trewiru, zawsze znajda schronienie $\mathrm{u}$ innych książąt. Władca Szwecji zaoferował braciom Ludwika XVI gościnę na Pomorzu. Pisał także, że chętnie zaprosiłby ich do Sztokholmu, ale zdaje sobie sprawę $z$ tego, że nie zechca oni opuścić swoich towarzyszy niedoli ${ }^{87}$.

Dokładnie w tym samym czasie Gustaw III napisał do Hansa Axela von Fersena, proszac go, aby przekazał baronowi de Breteuil, że on sam nie spodziewa się niczego dobrego po projektowanym

86 Por. Ludwik hrabia Prowansji i Karol hrabia d'Artois do Gustawa III, Koblencja 18 i 24 XII 1791, RA, Gallica vol. 521; Z. Anu sik, Dyplomacja..., s. 544; ide m, France..., s. 501-502.

87 Por. Gustaw III do Ludwika hrabiego Prowansji i Karola hrabiego d'Artois, pałacyk Haga 20 I 1792, N. Åke s o n, op. cit., Bd II, s. 242-244. W kwestii akredytacji C.G. Oxenstierny u boku elektora Trewiru por. ibidem, s. 195-196. Por. też Z. Anusik, Dyplomacja..., s. 545. 
kongresie, który może doprowadzić jedynie do skłócenia władców europejskich, a nie do ich zjednoczenia. Król był zresztą przekonany, że cesarz odmówi swojej zgody na jego zwołanie. Wielkie nadzieje wiązal natomiast $z$ polityka francuskiego Zgromadzenia Prawodawczego, które zmierzało prosto do rozpętania konfliktu zbrojnego. $Z$ tego też powodu naciskał na swojego posła w Brukseli, aby doprowadził on do jak najszybszego wyjazdu Ludwika XVI z Paryża. W tym samym dniu, 20 stycznia 1792 r., Ulric Gustaf Franc napisał do Johana Fredrika von Nolckena, że dwór sztokholmski nie akceptuje postawy cesarza, który nie chce przyjąć sposobu postępowania Szwecji, Rosji i Hiszpanii, które solidarnie odmówiły uznania wolności króla Francji. W związku z powyższą konstatacją sekretarz stanu postawił też pytanie, komu należałoby doręczyć wspólna notę władców europejskich, na której wysłanie nalegał dwór wiedeński. Nie królowi, bo ten nie jest panem samego siebie. Nie Zgromadzeniu, bo przez to samo należałoby uznać jego władzę, a nie można przecież paktować $z$ buntownikami. Piszac dalej, że w żadnym wypadku nie należy przywracać Ludwikowi XVI władzy droga rokowań, jak chcieliby to zrobić ministrowie cesarza, Franc zapewniał równocześnie Nolckena, że dwory północne, czyli Rosja i Szwecja, nigdy nie porzuca przyjętego przez siebie systemu i dlatego popierać będa wysunięta przez francuska parę królewska propozycję zwołania kongresu zbrojnego w okolicach Akwizgranu. Sądzić można, że nie mając wielkich nadziei na przekonanie cesarza o zasadności tego projektu, Gustaw III podjął wówczas ostatnią próbę osiągnięcia jakiegoś kompromisu $z$ dworem wiedeńskim. O wadze, jaką król przykładał do tego zagadnienia, świadczyć może wysłanie odpisu cytowanej depeszy do Curta von Stedingka w Petersburgu. Ponieważ w tym samym czasie dotarły do Sztokholmu pogłoski o możliwym odwołaniu Esterhazy'ego z Petersburga, 20 stycznia 1792 r. Gustaw III napisał do Carla Gustafa Oxenstierny, nalegając na niego, aby za wszelką cenę starał się o zatrzymanie hrabiego w stolicy Rosji, gdyż w innym przypadku emigranci moga stracić wszystko to, co dotąd uzyskali od Katarzyny $\mathrm{II}^{88}$.

${ }^{88}$ Por. Gustaw III do H.A. v. Fersena, pałacyk Haga 20 I 1792, RA, Stafsundsarkivet, Hans Axel von Fersens Samling. vol. 11; oraz U.G. Franc do J.F. v. Nolckena, Sztokholm 20 I 1792, apostille (kopia), RA, Muscovitica vol. 490. Por. też N. Åkeson, op. cit., Bd II, s. 201-202; Z. Anusik, Dyplomacja..., s. 545-546; ide m, France..., s. 503. 
Prawdopodobnie w tym samym czasie Gustaw III otrzymał kolejny list od barona de Breteuil z Brukseli. Baron przypominał królowi, że francuska para królewska w dalszym ciagu obstaje przy koncepcji zwołania kongresu zbrojnego u granic Francji i dlatego ponawia swoja prośbę o poparcie przez władcę Szwecji tej propozycji na innych dworach. Ludwik XVI jest bowiem przekonany, że kongres ułatwiłby jego dalsze działania i doprowadziłby do wzmocnienia jego pozycji w kraju. W dalszej części swojego listu Breteuil starał się więc delikatnie odwieść Gustawa III od zamiaru zbrojnej interwencji we Francji, starając się skierować cała jego uwagę i energię na sprawę organizacji kongresu. Naświetlając kwestię stosunków króla Francji z ksiażętami niemieckimi, baron pisał, że jego władca musi postępować $z$ wielką delikatnością ze względu na wrogość buntowników wobec Cesarstwa. Twierdził też, że elektorzy postapią mądrze i roztropnie, nie dajacc żadnej okazji do wrogich wobec siebie wystapień. Buntownicy czekaja bowiem tylko na pierwszy lepszy pretekst, aby zaatakować ich posiadłości. Król zaś nie będzie miał żadnych możliwości powstrzymania ich chęci zemsty za to, że niemieccy książęta udzielili u siebie gościny francuskim emigrantom. Baron twierdził także, że buntownicy mają nadzieję, że ich uderzenie na książąt nie spotka się $z$ żadna reakcją ze strony mocarstw i zamierzaja pójść na Niemcy z okrzykiem: „pokój chatom, wojna pałacom". Wyjaśniał Gustawowi III, że cała ta sytuacja skłania Ludwika XVI do daleko idącej ostrożności. Dlatego też król Francji zdecydował się zaakceptować decyzję Zgromadzenia o wysłaniu ultimatum do Koblencji $z$ żądaniem rozpuszczenia utworzonych tam przez francuskich emigrantów oddziałów. Dalsze decyzje króla zależeć miały od treści odpowiedzi elektora trewirskiego. Zdaniem barona francuska para królewska była jednak przekonana o tym, że emigranci powinni opuścić elektoraty duchowne. Mimo współczucia dla swoich nieszczęśliwych rodaków Breteuil całkowicie podzielał ten pogląd. Przewidywał też, że w swojej odpowiedzi na list elektora Trewiru cesarz będzie doradzał arcybiskupowi przyjęcie żądań francuskich i usunięcie ze swojego terytorium zbrojnych oddziałów emigrantów. To posunięcie powinno na razie zadowolić Zgromadzenie. W tym samym liście Breteuil poinformował Gustawa III, że Ludwik XVI nie ma jeszcze żadnego skonkretyzowanego planu działania, czekając na dalszy rozwój wydarzeń i zamierzając postapić stosownie do zmieniających się okoliczności. Wytaczając kolejne zarzuty pod adresem braci Ludwika XVI, baron wspomniał 
wreszcie o tym, że wysłany przez niego Marc Marie markiz de Bombelles zawiózł do Petersburga prywatne listy Marii Antoniny do Katarzyny II ${ }^{89}$. Ponieważ pomysły barona de Breteuil nie przypadły specjalnie do gustu królowi, a poza tym był on zajęty obradami riksdagu w Gävle, na odpowiedź ze Sztokholmu przyszło baronowi czekać przez kilka następnych tygodni. Gustaw III znalazł jednak czas na to, aby 30 stycznia 1792 r. napisać do Gustafa Adama von Nolckena w Londynie, zalecając mu śledzić $z$ najwyższą uwaga poczynania Charles'a Maurice'a de Talleyranda, wysłanego przez Zgromadzenie Prawodawcze $z$ misja specjalna na dwór angielski ${ }^{90}$.

Obserwujacc uważnie rozwój sytuacji w Europie Zachodniej, Gustaw III nie tracił $z$ pola widzenia problemów Europy Środkowo-Wschodniej. Tu zaś w początkach 1792 r. dokonały się zmiany o ogromnym ciężarze gatunkowym. Dnia 9 stycznia Rosja zawarła bowiem w Jassach definitywny traktat pokojowy $z$ Turcja (na bazie podpisanych 11 sierpnia 1791 r. w Gałaczu układów preliminaryjnych). Zakończenie wojny tureckiej oznaczało zaś, że cesarzowa odzyskała pełną swobodę ruchów i w Sztokholmie (gdzie Gustaw III nie tracił nadziei na uzyskanie korony po Stanisławie Auguście) zaczęto się obawiać, że Katarzyna II rozpocznie przygotowania do interwencji w Polsce ${ }^{91}$. W początkach lutego 1792 r. cesarzowa przedstawiła szwedzkiemu królowi opracowany przez siebie plan

89 Por. L.A. de Breteuil do Gustawa III, Bruksela 1 I 1792, RA, Gallica vol. 524. Ten sam list por. M. Price, op. cit., s. 459-462. Por. też Z. Anusik, Dyplomacja..., s. 546-547; id e m, France..., s. 504.

${ }^{90}$ Por. N. Åkeson, op. cit., Bd II, s. 198-199; Z. Anusik, Dyplomacja..., s. 547; ide m, France..., s. 504-505.

91 N. Åkeson twierdził, że od chwili zakończenia wojny rosyjsko-tureckiej Katarzyna II robiła wszystko, aby uwikłać inne państwa europejskie w wojnę przeciwko Francji po to, żeby mieć wolne ręce wobec Rzeczypospolitej. Por. idem, op. cit., Bd II, s. 202. Por. też C.T. Odhner, Gustaf III och Katarina II efter..., s. 57-58. Podobnie uważał B. Dembiński, który twierdził, że Katarzyna II od poczatku jedynie udawała zainteresowanie sprawami rewolucyjnej Francji, podczas gdy naprawdę myślała o wywarciu swojej zemsty na Polsce i Polakach. Por. id e m, Rosya a Rawolucya Francuska, Kraków 1896, s. 141, 159 n., 171 n., 177-178. W rzeczywistości jednak sprawa była nieco bardziej skomplikowana i wydaje się, że ostateczna decyzja dworu petersburskiego o rozpoczęciu interwencji w Polsce zapadła dopiero na przełomie marca i kwietnia 1792 r. Por. Z. Anusik, Między Warszawa, Sztokholmem i Petersburgiem. Geneza rosyjskiej interwencji $w$ Polsce $w 1792$ roku $w$ świetle korespondencji ambasadora szwedzkiego $w$ Petersburgu - Curta von Stedingka, [w:] Przełomy w historii. XVI Powszechny Zjazd Historyków Polskich (Wrocław 15-18 września 1999 roku). Pamiętnik, t. II, cz. 1, Toruń 2000, s. 255-276. 
operacji przeciwko rewolucyjnej Francji. Zgodnie z projektem Katarzyny II mocarstwa zainteresowane przywróceniem starego ładu $\mathrm{w}$ tym kraju miały w pierwszym rzędzie zatroszczyć się o zgromadzenie środków finansowych na uzbrojenie oddziałów francuskich emigrantów. Armia austriacka miała zostać skoncentrowana w Belgii oraz w Bryzgowii, a król pruski miał wzmocnić swoje siły zbrojne w Nadrenii. Podobnie mieli postapić władcy Hiszpanii oraz Sardynii, przesuwając swoje wojska w kierunku granic Francji. Siły sprzymierzonych miały jednak ograniczyć się do zbrojnej demonstracji, stanowiąc jednocześnie osłonę dla oddziałów francuskich emigrantów, które jako jedyne miały przekroczyć granicę. Plan przygotowany na dworze petersburskim zakładał również zwołanie zbrojnego kongresu mocarstw w sprawie Francji. Nie przewidywał jednak wysłania do tego kraju rosyjskich żołnierzy. Zmierzał też do ograniczenia do minimum udziału Szwecji w całym przedsięwzięciu $^{92}$.

92 Por. N. Åke s o n, op. cit., Bd II, s. 203-204. Pod względem proponowanych rozwiązań szczegółowych plan Katarzyny II przedstawiony w jej liście do Gustawa III z 20 I 1792 r. wyglądał następująco: 1) Sprzymierzone mocarstwa zapewnią kontyngent środków finansowych przypadających na każde $z$ nich proporcjonalnie do interesów, bliskości sąsiedztwa i zasobów, którymi zamierzaja podtrzymać dobrą sprawę. Fundusze, które w ten sposób zostana zgromadzone, zostana przeznaczone przede wszystkim na wspomożenie książąt i ich partii, jak również na pokrycie wydatków związanych ze zbrojeniami, które podejmą. 2) Cesarz mający znaczna armię w swoich Niderlandach zadowoli się rozmieszczeniem jej w sposób, który pozwoli na zatrzymanie Francuzów na ich granicach $z$ tej strony. Wzmocni on jednak swoje oddziały w Bryzgowii, podobnie jak król pruski w swoich posiadłościach w Nadrenii, stosownie do tego, co zaproponuja książęta emigranci w tej sprawie. 3) Hiszpania i Sardynia obsadza swoje granice oddziałami w liczbie stosownej do ich możliwości i w sposób uzgodniony wcześniej z cesarzem i królem pruskim. Wszystkie te działania powinny zostać zakończone przed nadejściem wiosny, tak aby nie opuścić pierwszej sprzyjającej okazji, która się nadarzy. 4) Oddziały sprzymierzonych mocarstw nie będa miały potrzeby podejmować na razie żadnych wrogich działań, ale będą przeznaczone do zabezpieczenia ze wszystkich stron operacji emigrantów i tych, którzy opowiedzą się za nimi. W razie konieczności zabezpieczą również odwrót wojsk emigrantów, udzielając im posiłków i dostarczając żywności, amunicji i innych materiałów wojennych. 5) Po głębokiej rozwadze należy też dojść do wniosku, że nie należy odkładać zbyt długo momentu wkroczenia emigrantów do Francji i nie należy powstrzymywać ich przed rozpoczęciem planowanych przez nich operacji, tym bardziej że król Szwecji będzie gotowy do wsparcia tych działań w wybranym przez siebie miejscu już na początku wiosny. 6) Skoro król i królowa Francji wydaja się chcieć zwołania kongresu pod pretekstem sprawy Awinionu i sprawy książąt niemieckich mających posiadłości we Francji, i skoro ambasador francuski - $z$ tego, co wiemy - złożył formalna propozycję w tej sprawie na dworze wiedeńskim, ten pomysł wydaje się możliwy do 
Niezadowolony $z$ takiego obrotu wydarzeń, Gustaw III zaczął podejrzewać Katarzynę II o chęć wycofania się $z$ aktywnej polityki wobec Francji. Dnia 6 lutego 1792 r. rozkazał więc Curtowi von Stedingkowi, aby dowiedział się, czy cesarzowa nie zamierza czasami dokonać interwencji w wewnętrzne sprawy Rzeczypospolitej. Król uważał, że gdyby tak wyglądały prawdziwe zamiary jego kuzynki, byłoby to posunięcie, które w mniejszym lub większym stopniu musiałoby spowodować zmianę jej polityki wobec Francji. Interwencja w Polsce nie pozwoliłaby jej bowiem zajmować się $z$ dotychczasowym animuszem popieraniem wspólnej sprawy wszystkich monarchów. Gustaw III przewidywał fatalne konsekwencje takiej decyzji Katarzyny II. Jego zdaniem inne dwory, pozbawione wsparcia ze strony Rosji, także mogłyby bowiem wpaść na pomysł wycofania się $z$ zamiaru interwencji w wewnętrzne sprawy Francji ${ }^{93}$.

Na razie jednak król Szwecji nie miał ani czasu, ani też powodu, żeby zajmować się dłużej sprawą swoich podejrzeń co do ukrytych motywów wpływających na aktualne poczynania Katarzyny II. Riksdag w Gävle uchwalił bowiem żądane przez niego podatki i pozwolił mu wyjść $z$ kryzysu finansowego, w jakim od dawna był pograżony. Unormowanie spraw skarbowych we własnym kraju stanowiło też dobry prognostyk na przyszłość. Nowe podatki oraz spodziewane subsydia zagraniczne mogły bowiem dać królowi do dyspozycji środki finansowe wystarczające do zorganizowania planowanej od dawna wyprawy przeciwko rewolucyjnej Francji ${ }^{94}$. O tym, że eks-

$\overline{\text { przyjęcia, gdyż będzie on sprzyjał przesunięciu oddziałów, albowiem w oczekiwa- }}$ niu na rozpoczęcie negocjacji trzeba będzie przygotować odpowiednie siły militarne dla ich podtrzymania. Wydaje się też konieczne, aby miejsce obrad przyszłego kongresu zostało wyznaczone już w czasie obecnie trwającej zimy lub też zaraz na początku wiosny, tak żeby można było jeszcze na wiosnę rozpocząć działania militarne, jeśli w ogóle miałoby do nich dojść. Por. Gustaw III do C. v. Stedingka, pałacyk Haga 2 III 1792, apostille nr 2 (Copie de la Plan mentionné dans la lettre de l'Imperatrice au Roi), RA, Muscovitica vol. 490. Warto może w tym miejscu zwrócić uwagę na to, że plan przesłany przez Katarzynę II Gustawowi III był w zasadzie zgodny $z$ projektem opracowanym wcześniej na dworze hiszpańskim, co nie uszło zreszta uwagi króla. Nie wiedział on jednak tego, że zanim propozycja rosyjska trafiła do Sztokholmu, została ona przedstawiona w Wiedniu i w Berlinie. Por. B. Dembiński, op. cit., s. 194-195. Por. też Z. Anusik, Dyplomacja..., s. 547-549; id e m, France..., s. 505-506.

${ }^{93}$ Por. Gustaw III do C. v. Stedingka, Gävle 6 II 1792, RA, Muscovitica vol. 490.

${ }^{94} \mathrm{~W}$ sprawie przebiegu i uchwał riksdagu w Gävle por. J.A. Almquist, Riksdagen i Gefle 1792, Upsala 1895; H.A. Barton, Scandinavia..., s. 196-197; R.N. Bain, op. cit., vol. II, s. 161-184; E. Schröderheim, op. cit., s. 102-1155. 
pedycja ta dojdzie wreszcie do skutku, przekonany był zarówno sam Gustaw III, jak i uważni obserwatorzy sztokholmskiej sceny politycznej. W swoich depeszach z 13 i 14 lutego 1792 r. kawaler Jean de Gaussen pisał bowiem, że do wyprawy przeciwko Francji król przygotowuje korpus liczący 12-15 tys. żołnierzy, których zamierza oddać pod dowództwo Everta Taubego ${ }^{95}$. W tym samym mniej więcej czasie stary przeciwnik polityczny Gustawa III, Fredrik Axel von Fersen pisał do swojego syna Fabiana: „Mam częste nowiny od twojego brata $z$ Brukseli. Nie jestem jednak wtajemniczony w przedmiot jego misji. Wiem tylko, że kłótnie między cesarzem, książętami i Zgromadzeniem Narodowym (Legislatywą) coraz bardziej się gmatwają i wszystko zapowiada podniesienie tarczy - a w takim przypadku nasza nieszczęśliwa Szwecja na pewno będzie $\mathrm{w}$ to wciagnnięta i $\mathrm{w}$ ostatecznym rozrachunku otrzyma cios łaski"96. Jedyne, co w lutym 1792 r. mogło martwić wszystkich zwolenników króla, to to, że zarówno w czasie trwania obrad riksdagu w Gävle, jak i wkrótce po jego zakończeniu pojawiły się pogłoski o planowanym zamordowaniu Gustawa III przez francuskich jakobinów ${ }^{97}$. Król jednak nie przejmował się niczym, wyraźnie lekceważąc grożące mu $z$ tej strony niebezpieczeństwo.

Dnia 20 lutego 1792 r. władca Szwecji zdecydował się wreszcie odpowiedzieć na list barona de Breteuil $z 1$ stycznia tego roku. Przepraszając za zwłokę w udzieleniu odpowiedzi (riksdag w Gävle), Gustaw III wyraził równocześnie nadzieję, że ten rok będzie wreszcie szczęśliwy dla Francuzów, którzy będą mogli ujrzeć swoją ojczyznę ocaloną, a swojego władcę przywróconego na tron. Dalej król pisał, że obawy barona, który ostrzegał go przed zwołaniem riksdagu, okazały się bezpodstawne. Wszystko idzie bowiem dobrze, a partia regalistyczna ma tak ogromna przewage w trzech niższych stanach, że zmusza to do zachowania spokoju szlachecka opozycję. Gustaw III przewidywał, że w ciagu ośmiu najbliższych dni zakończy wszystkie swoje sprawy w Szwecji. Uznał to za niezbędny warunek zorganizowania planowanej ekspedycji, gdyż „chcąc przywrócić porządek u innych, należy zacząć od przywrócenia go

Por. też N. Åkeson, op. cit., Bd II, s. 220; Z. Anusik, Dyplomacja..., s. 549; idem, France..., s. 507.

95 Por. A. Söderhjelm, Sverige..., s. 305.

96 Cyt. według ibidem, s. 307.

97 Por. N. Åkeson, op. cit., Bd II, s. 219-1220; Z. Anusik, Dyplomacja..., s. 550; idem, France..., s. 507. 
u siebie". W dalszej części tego listu władca Szwecji skarżył się na to, że rokowania $z$ Hiszpanią nie posunęły się naprzód, co może wpłynąć na opóźnienie planowanych działań. Na szczęście jednak król pruski przysłał pomyślna odpowiedź. To sprawia, że cesarz znalazł się w prawdziwym kłopocie, gdyż Gustaw III, Katarzyna II i Fryderyk Wilhelm II naciskają na niego, aby odsłonił swoje prawdziwe zamiary. $Z$ drugiej strony szaleństwo Zgromadzenia nadaje sprawom tak szybki bieg, że trzeba już teraz być gotowym do przyszłego działania. $Z$ tego powodu król Szwecji zamierzał oświadczyć Katarzynie II, że jest gotów do rozpoczęcia działań bez czekania na rosyjskie subsydia. W jego przekonaniu oświadczenie to powinno skłonić dwór petersburski do szybszego wysłania własnych wojsk. Od Breteuila król żądał natomiast, aby przyśpieszył on decyzję Hiszpanów w sprawie współfinansowania jego wyprawy do Francji. Twierdził także, „że gdyby mocarstwa, które wysłały książętom ogromne sumy, szacowane łącznie na ponad 12 milionów liwrów, $z$ których to sum nic już nie pozostało, przekazały jemu chociaż część tych pieniędzy jesienią ubiegłego roku, prawdopodobnie miałby już w swoim ręku przynajmniej jedna prowincję i znajdowałby się w położeniu zdecydowanie lepszym od obecnego". Na zakończenie król poinformował barona, że przed trzema dniami dotarł do niego młody hrabia de Bouillé, który przywiózł plan operacji opracowany przez jego ojca. Przewidywał on zajęcie Dunkierki i marsz oddziałów interwencyjnych na Paryż. W tym samym czasie Hiszpania i Sardynia miały zaś zagrozić granicom Francji od południa. Gustaw III przekonywał też Breteuila, że trzeba działać bez straty czasu, korzystając $z$ tego, że Katarzyna II jest dobrze usposobiona, a cesarz nie może zbytnio przeszkadzać. Król wspomniał również, że chciałby, aby wprowadzono w życie rady, których udzielał Ludwikowi XVI. Chodziło mu w tym wypadku o zorganizowanie nowej ucieczki króla Francji z Paryża ${ }^{98}$.

W końcu lutego 1792 r. Gustaw III zaakceptował plan lądowania wojsk szwedzkich w Normandii ${ }^{99}$. W tym samym czasie napisał też

98 Por. Gustaw III do L.A. de Breteuila, Gävle 20 II 1792, N. Åke s o n, op. cit., Bd II, s. 245-246. Por. też ibidem, s. 219. Ten sam list por. M. Price, op. cit., s. 462-463. Por. też Z. Anu sik, Dyplomacja..., s. 550-551.

${ }^{99}$ Por. A. Söderhjelm, Sverige..., s. 307. W związku z planowanym lądowaniem szwedzko-rosyjskiego korpusu ekspedycyjnego na wybrzeżach Normandii, 30 III 1792 r. francuski oficer de Vaugiraud, który służył niegdyś pod rozkazami admirała François Josepha de Grasse'a w wojnie amerykańskiej, przygotował (nieco już spóźniona) notę o aktualnym stanie francuskich portów wojennych. 
do Hansa Axela von Fersena, informując go o planie wspólnych działań przedstawionym w Sztokholmie przez Katarzynę II. Zdaniem króla plan rosyjski nie różnił się niczym od starego planu opracowanego na dworze madryckim. $Z$ tego też powodu Gustaw III wypowiadał się o nim bardzo niechętnie. Pisał także, że cesarzowa nie dostała jeszcze definitywnej odpowiedzi od Leopolda II, a bez znajomości stanowiska cesarza trudno cokolwiek planować. Król utyskiwał także na niezgodę i nieufność w stosunkach pomiędzy Ludwikiem XVI a jego braćmi, co stanowiło istotna przeszkodę w działaniach na ich korzyść. Od Fersena żądał, aby podwoił naciski na Breteuila, żeby ten zdobył pieniądze na sfinansowanie ekspedycji wojsk szwedzkich. Bez pieniędzy król nie będzie bowiem mógł niczego zrobić, a jeśli on się wycofa, to cała sprawa upadnie. Ubolewajac nad niepotrzebna strata czasu, Gustaw III stwierdził na koniec, że nic nie zdoła przekonać Katarzyny II, żeby porzuciła sprawę książąt, których od początku zdecydowała się protegować. On sam stracił co prawda cała sympatię dla braci Ludwika XVI,

Zgodnie $z$ jego relacją w portach Brest, L'Orient i Rochefort w końcu marca 1792 r. stacjonowały 42 okręty liniowe: sześć o 100 działach, cztery o 80 i 32 wyposażone w 74 armaty. Nie wszystkie były jednak odpowiednio przygotowane do służby. Nikt też nie zajmował się ich przygotowaniem do wojny. Zgromadzenie Prawodawcze nie powzięło bowiem żadnej decyzji w tym względzie. Vaugiraud podkreślał słabe wyszkolenie dowódców i załóg. Wspomniał też o wysłaniu dwóch liniowców i trzech fregat do francuskich kolonii. Pisał, że dla obrony portów buntownicy moga uzbroić zaledwie osiem okrętów w Breście, jeden w L’Orient i trzy w Rochefort, a cała eskadra francuska może być gotowa do wyjścia w morze dopiero w końcu czerwca. Ma jednak poważne kłopoty z zaopatrzeniem. Wszystkie trzy porty moga bowiem dostarczyć żywność tylko dla sześciu okrętów. Kupcy odmawiają bowiem przyjmowania zapłaty w asygnatach. Informator szwedzkiego króla twierdził też, że Brest nie będzie w stanie wyposażyć nawet 12 okrętów, gdyż w mieście panuje niepokój, marynarze sa niezadowoleni i maja ustawiczne zatargi z komisarzem Zgromadzenia, a żaglownicy nie chcą więcej pracować. Jego zdaniem w Breście panować miał bałagan, nieporządek i rozgardiasz, co musiało znacznie utrudnić jakiekolwiek działania francuskiej floty. Jeśli więc Zgromadzenie nie wyda rozkazów dotyczących rozpoczęcia zbrojeń, będzie trudno wystawić w końcu czerwca flotę większą niż 12 liniowców. Vaugiraud przewidywał też, że w początkach tego miesiąca w służbie może być tylko kilka fregat i jeden liniowiec. Francuski oficer proponował więc zablokować te porty, podobnie jak porty handlowe w Nantes, La Rochelle i Bordeaux. Do swojej noty dołączył szczegółową listę okrętów, które znajdowały się w wymienionych portach. W swoim raporcie nie wspominał natomiast o Tulonie, który jego zdaniem był zbyt oddalony od miejsca planowanego lądowania wojsk interwencyjnych. Twierdził jednak, że jeśli w okolicach tego portu dojdzie do wybuchu kontrrewolucji, to nie odegra on żadnej roli w zbliżajaccej sie kampanii. Por. Note sur l'état actuel des ports de guerre de France, RA, Gallica vol. 555. Por. też Z. Anu sik, Dyplomacja..., s. 551; ide m, France..., s. 508-509. 
ale nie widział innego wyjścia. Uznał, że musi popierać ich interesy, bo to utrzymuje zainteresowanie Katarzyny II dla spraw Francji i Ludwika XVI ${ }^{100}$. Dnia 2 marca 1792 r. Gustaw III ponownie napisał do Fersena. Był bowiem przekonany o konieczności zorganizowania ucieczki Ludwika XVI z Francji. Król pisał, że jeśli ze względu na uchwalona przez Legislatywę ustawę o paszportach hrabia nie będzie mógł osobiście pojechać do Paryża, ucieczkę króla powinni zorganizować Anglicy. Za najlepszego kandydata do wykonania tego przedsięwzięcia uznał Jamesa Quentina Craufurda. Pisał także, że zaproponował wcześniej to samo markizowi de Bouillé, ale nie otrzymał od niego żadnej odpowiedzi. Na koniec wreszcie Gustaw III stwierdził, że jego zdaniem Fersen byłby odpowiednim wysłannikiem Ludwika XVI na dwór angielski. Dlatego też postanowił przesłać mu listy polecające do Jerzego III, które w razie potrzeby mogłyby posłużyć hrabiemu za listy kredencjonalne ${ }^{101}$.

Dnia 2 marca 1792 r. Gustaw III napisał także do Curta von Stedingka, informując go o tym, że Katarzyna II mocno naciska na niego, aby zgodził się na przyjęcie jej projektu zakładającego, że to książęta odegrają pierwszoplanową rolę w czasie przyszłej interwencji we Francji. Zdaniem króla, był to poważny błąd, zarówno ze względu na rozbicie panujące wśród emigrantów przebywających w Koblencji, jak i z powodu niekonsekwencji, żeby nie powiedzieć nicości osób, które prowadza sprawy książąt. Gustaw III przewidywał, że słabość emigrantów sprawi, że ich działania nie przyniosa żadnego rezultatu. Książęta zaś, otoczeni przez małe intrygi, odurzeni przez paplanie kobiet, traca czas i trwonia pieniądze, które im przesłano na niepotrzebne wydatki. Nie należy się więc spodziewać żadnej skuteczności $z$ ich strony. $Z$ tego powodu król chciałby uniknać współdziałania wojskowego $z$ bezwartościowa armią emigrantów. Stedingk otrzymał więc polecenie, żeby delikatnie przekonał Katarzynę II do tego pomysłu. Stanowczo bowiem należało oddzielić operacje Szwedów i Rosjan od operacji emigrantów. W głębokim przekonaniu Gustawa III najlepszym rozwiazaniem byłby desant w Normandii. Książęta woleliby co prawda lądowanie Szwedów i Rosjan w Emden i atak na Charlemont, ale zdaniem króla był to

100 Por. Gustaw III do H.A. v. Fersena, Sztokholm 28 II 1792, N. Åkes on, op. cit., Bd II, s. 247-248; Z. An u sik, Dyplomacja..., s. 551-552; id e m, France..., s. $508-509$.

101 Por. Gustaw III do H.A. v. Fersena, Sztokholm 2 III 1792, RA, Stafsundsarkivet, Hans Axel von Fersens Samling. vol. 11. Por. też Z. A nu sik, Dyplomacja..., s. 552; ide m, France..., s. 509-510. 
zły pomysł i Stedingk miał przekonać o tym Katarzynę II. Od Stackelberga monarcha dowiedział się, że cesarzowa zamierza przeznaczyć na wyprawę do Francji 16-17 tys. żołnierzy. Uznał to za liczbę wystarczająca do realizacji swoich planów. Odnosząc się do kwestii rywalizacji między księciem Karlem von Nassau a markizem de Bouillé o wpływy w dowództwie przyszłej wyprawy, Gustaw III zaznaczył, że chciałby, aby Nassau dowodził połączona flotyllą szwedzko-rosyjską, a Bouillé - siłami lądowymi. Na zakończenie swojego listu król wspomniał także o kwestii przystapienia Hiszpanii do traktatu drottningholmskiego. Mimo zastrzeżeń dworu petersburskiego, który wskazywał na to, że sojusz szwedzko-rosyjsko-hiszpański mógłby zaalarmować Anglię, która mogłaby w rezultacie przeszkodzić w lądowaniu sprzymierzonych we Francji, Gustaw III był przekonany o potrzebie podpisania układu sojuszniczego $z$ Karolem IV. Jego zdaniem zacieśnienie współpracy $z$ dworem madryckim mogłoby polegać albo na jego bezpośrednim akcesie do traktatu $z$ Drottningholmu, albo też na zawarciu $z$ nim osobnego układu ${ }^{102}$.

Dnia 4 marca 1792 r. Gustaw III napisał też wreszcie do Katarzyny II, która starał się delikatnie odwieść od forsowania przedstawionego mu na początku lutego planu przyszłych działań wobec Francji. Rozpoczął od wyrażenia zadowolenia $z$ tego, że oba dwory dokładnie w ten sam sposób patrza na sprawy francuskie. Dalej pisał, że postępuje bardzo oględnie wobec cesarza, zdając sobie sprawę $z$ konieczności jego pozyskania. Dlatego też wysłał do barona Nolckena w Wiedniu rozkazy, aby postępował on tak samo, jak poseł rosyjski w austriackiej stolicy. Gustaw III zapewniał też cesarzowa, że jej plan jest wręcz doskonały. Zwracał jednak uwage na to, że czas ucieka, a mocarstwa nie sa jeszcze gotowe do działania. Twierdził również, że decydujący cios musi zostać zadany przez wojska szwedzkie i rosyjskie. Tylko ich zwycięstwa umożliwią bowiem książętom wkroczenie do Francji. Dlatego też władca Szwecji wystapił $z$ propozycja, aby bez dalszej zwłoki przystapić do koncentracji oddziałów i wysłać je do Francji. Polecając łasce Katarzyny II księcia von Nassau, bardzo oddanego dobrej sprawie, Gustaw III wyraził też pogląd, że po odniesieniu zwycięstwa Ludwik XVI powinien przykładnie ukarać wszystkich buntowników. Za jedno $z$ najważniejszych zadań sprzymierzonych dworów

102 Por. Gustaw III do C. v. Stedingka, pałacyk Haga 2 III 1792, RA, Muscovitica vol. 490. Por. też Z. Anusik, Dyplomacja..., s. 552-553; idem, France..., s. $510-511$. 
uznał też nakłonienie Marii Antoniny do zawarcia ugody z książętami. W końcowej partii tego listu Gustaw III nie powstrzymał się jednak od wytoczenia pod adresem emigrantów zarzutów, że bezmyślnie zmarnotrawili przyznane im pieniądze. Swoje wywody w tej sprawie zakończył dobitnym stwierdzeniem, że to nie książęta powinni działać na pierwszej linii wydarzeń, lecz wojska szwedzkie i rosyjskie ${ }^{103}$.

Warto w tym miejscu podkreślić to, że przez cały ten czas Gustaw III nie tracił $z$ oczu spraw polskich. Mimo uspokajajacych doniesień z Petersburga, nie wyzbył się podejrzeń co do tego, że Katarzyna II planuje jednak dokonanie inwazji na Rzeczpospolita. Król nie ujawniał jednak cesarzowej swoich wątpliwości i w pierwszej połowie marca 1792 r. między Sztokholmem a Petersburgiem trwała wymiana korespondencji, której celem było uzgodnienie wspólnego stanowiska w sprawie organizacji planowanej wyprawy przeciwko Francji. Kiedy jednak w tym samym czasie Otto Magnus von Stackelberg rozpoczał w Sztokholmie ostrożne sondaże w sprawie stanowiska, jakie zajmie Szwecja na wypadek rosyjskiej interwencji w Polsce, Gustaw III postanowił wymusić na Katarzynie II realne ustępstwa w zamian za zachowanie neutralności w przewidywanym konflikcie. Dnia 13 marca 1792 r. napisał więc do Curta von Stedingka, informując go o swoich rozmowach ze Stackelbergiem. Stwierdził przy tej okazji, że jest zdecydowanie przeciwny rosyjskiej interwencji w Rzeczypospolitej, gdyż spowoduje ona odwrócenie uwagi cesarzowej od spraw francuskich. Rozkazał też Stedingkowi, aby starał się przekonać Katarzynę II o konieczności zajęcia się w pierwszym rzędzie problemami Francji. Odmawiając stanowczo wyrażenia zgody na sugerowane przez Stackelberga przystapienie Danii do sojuszu szwedzko-rosyjskiego, Gustaw III polecił swojemu ambasadorowi, aby dowiedział się, jakie sa prawdziwe zamiary dworu petersburskiego. Pisał też, że obecne okoliczności powinny przynieść Szwecji namacalne korzyści. Musi on jednak wiedzieć, do czego zmierza cesarzowa, aby mógł w sposób optymalny wykorzystać nadarzająca się okazję. Zakładając, że Katarzyna II szykuje nowy rozbiór Polski, należałoby się upewnić, czy sprawy Francji nie służą jej tylko do odciagnięcia uwagi sąsiadów od spraw Rzeczypospolitej. Jest bowiem wielce prawdopodob-

103 Por. Gustaw III do Katarzyny II, pałacyk Haga 4 III 1792, N. Åkeson, op. cit., Bd II, s. 248-250. Por. też ibidem, s. 204; oraz Z. Anu sik, Dyplomacja..., s. 553-554; id e m, France..., s. 511. 
ne, że carowa chce uwikłać króla Szwecji na Zachodzie po to, żeby sama mogła wyciagnać wszystkie korzyści $z$ nowego podziału Rzeczypospolitej. Nie odrzucając myśli o rozbiorze Polski, Gustaw III wysuną sugestię, że w takim wypadku Katarzyna II mogłaby rozważyć możliwość zajęcia się obu sprawami równocześnie, wysyłając do Francji oddziały, które w innych okolicznościach (obecnie władca Szwecji jest jej sojusznikiem) musiałaby trzymać na granicy Finlandii. Aczkolwiek król pisał dalej, że tylko $z$ trudem mógłby uwierzyć w to, że cesarzowa chciałaby porzucić sprawę, dla której okazywała dotą tak żywe zainteresowanie, to jednak zakończył swój list następującym stwierdzeniem: „Jak by jednak nie było, czy cesarzowa chciałaby szczerze i bez żadnych ukrytych celów politycznych wziąć udział w rozstrzyganiu spraw francuskich, czy też chciałaby posłużyć się nimi tylko po to, aby mieć wolne ręce w stosunku do Polaków, jest sprawą najwyższej wagi, abym znał jej zamiary, żeby nie wystawić się na jakieś fałszywe działania i nie stracić okazji do wyciagnięcia korzyści ze sprzyjajacych okoliczności, jeśli takie będą miały miejsce”. Innymi słowy, Gustaw III uważał, że gdyby jego podejrzenia okazały się słuszne, Katarzyna II powinna sowicie zapłacić nie tylko za jego rezygnację $z$ ubiegania się o koronę po Stanisławie Auguście, lecz także być może za odstapienie od pomysłu zorganizowania monarchistycznej krucjaty przeciwko rewolucyjnej Francji ${ }^{104}$.

Jeśli jednak król Szwecji chociaż przez chwilę myślał o rezygnacji ze zorganizowania ekspedycji mającej przynieść wybawienie Ludwikowi XVI i jego rodzinie, to nie ujawnił tego przed baronem de Breteuil. Dnia 13 marca 1792 r. pisał bowiem do niego, że uporał się $z$ wszystkimi problemami wewnętrznymi i jest gotowy do rozpoczęcia działań. Wyrażając radość $z$ powodu rokowań prowadzonych przez barona w Berlinie, żalił się jednak, że jego własne rokowania $z$ Hiszpania nie są tak szczęśliwe. Mimo swoich podejrzeń wyrażonych expressis verbis w liście do Stedingka, Gustaw III zapewniał Breteuila, że Katarzyna II nadal pozostaje w dobrej dyspozycji. Ostrzegał jednak swojego korespondenta, że on sam nie będzie mógł niczego zdziałać bez hiszpańskich subsydiów. Niepo-

104 Por. Gustaw III do C. v. Stedingka, Sztokholm 13 III 1792, RA, Muscovitica vol. 490. Ten sam list por. też N. Åke s o n, op. cit., Bd II, s. 251-253. Jego streszczenie por. ibidem, s. 205-206. Por. też C.T. Odhner, Gustaf III och Katarina II efter..., s. 60-61; R.N. Bain, op. cit., vol. II, s. 187-189; Z. Anusik, Dyplomacja..., s. 554-555; id e m, France..., s. 511-512. 
koił się także tym, że Austria i Prusy dążyć miały do wykluczenia $z$ operacji przeciwko Francji dworów północnych. Wskazywał na niebezpieczeństwo, w jakim znalazłaby się Francja, gdyby o jej losie decydowały tylko Berlin i Wiedeń, bez udziału Szwecji i Rosji. Wyrażając nadzieję, że Breteuil przyśle mu w najbliższym czasie pieniądze, król prosił też barona o rychłą odpowiedź, żeby mógł poczynić odpowiednie do jej treści przygotowania ${ }^{105}$. W tym samym dniu Gustaw III napisał również do Hansa Axela von Fersena, prosząc go o rozważenie możliwości przygotowania ucieczki Ludwika XVI do Anglii lub do Flandrii ${ }^{106}$.

Cytowane wyżej listy wyraźnie wskazują na to, że Gustaw III nie zamierzał bynajmniej rezygnować $z$ odegrania czołowej roli na europejskiej scenie politycznej. Wszystkie jego plany i zamiary zupełnie niespodziewanie zostały jednak przekreślone. Grupa fanatycznych przeciwników króla ze stanu szlacheckiego przygotowała bowiem spisek na jego życie. Dnia 16 marca 1792 r. były kapitan gwardii królewskiej - Jacob Johan Anckarström śmiertelnie ranił Gustawa III na balu maskowym w sztokholmskiej ope$\mathrm{rze}^{107}$. W ten sposób wyeliminowany został $z$ rozgrywki politycznej człowiek, którego poczynania mogły w znaczący sposób wpłynąć na rozwój wydarzeń tak w zachodniej, jak i we wschodniej części kontynentu europejskiego. Można też podejrzewać, że wbrew temu, co pisał z Petersburga Curt von Stedingk, Katarzyna II nie miała najmniejszego powodu, aby żałować, że dokonano zamachu na życie Gustawa III. Po wieści o śmierci Leopolda II, który zmarł

105 Por. Gustaw III do L.A. de Breteuila, Sztokholm 13 III 1792, N. Åkes on, op. cit., Bd II, s. 251. Ten sam list por. M. Price, op. cit., s. 463. Por. też Z. Anu sik, Dyplomacja..., s. 555; id e m, France..., s. 512-513.

106 Por. A. Söderhjelm, Sverige..., s. 295; N. Åkeson, op. cit., Bd II, s. 217-218.

107 W sprawie spisku na życie króla por. H.A. Barton, Scandinavia..., s. 201202; R.N. Bain, op. cit., vol. II, s. 153-158, 188-198; B. Hennings, Gustav III. En biografi..., s. 312-317; A. Geffroy, op. cit., t. II, s. 279-292; B. v. Schinke1, Minnen ur Sveriges nyare historia samlade af..., utg. af C.W. Bergman, Del. II (Gustaf III och hans tid 1788-1792), Stockholm 1852, s. 201-217; C. N ord m a n n, op. cit., s. 250-260. Głównymi uczestnikami tego sprzysiężenia byli: Adolf Ludvig Ribbing, Ture Bielke, Clas Fredrik Horn, Carl Pontus Liljehorn, Jacob Engeström oraz Jacob Johan Anckarström. Za kulisami ukrywał się jednak stary wróg króla - Carl Gustaf Pechlin. Bliższe informacje o zabójcy i głównym animatorze zamachu por. L. Stavenow, Anckarström Jacob Johan, [w:] Svenskt Biografiskt Lexikon, Bd I, Stockholm 1918, s. 610-614; oraz H. Lindberg, En ränksmidare. Strödda blad ur 1700-talets partistrider, Stockholm 1928. 
1 marca 1792 r., była to bowiem druga w przeciagu bardzo krótkiego okresu pomyślna dla niej wiadomość. Obaj władcy stanowili wszak potencjalnie poważne zagrożenie dla lansowanego w jej otoczeniu projektu dokonania zbrojnej interwencji w Rzeczypospolitej. Ich zniknięcie ze sceny politycznej zdawało się natomiast usuwać ostatnie przeszkody na drodze do jego realizacji.

Zupełnie inaczej reagowali jednak zwolennicy dotychczasowej linii politycznej króla szwedzkiego. Dnia 25 marca 1792 r. baron de Breteuil, nie wiedząc jeszcze o tragedii, która wydarzyła się w Sztokholmie, napisał swój ostatni list do Gustawa III. Pisał w nim, że przykład króla Szwecji bardzo korzystnie wpłynął na postępowanie Fryderyka Wilhelma II, okazującego coraz więcej zainteresowania dla spraw Francji. Podobnie dobrze usposobiony wydawał się baronowi młody król Węgier (Franciszek II), naśladujący przykład cesarza Józefa II i korzystający z rad cesarzowej Rosji. Breteuil pocieszał się też nadzieją, że król Węgier zdecyduje się na porozumienie $z$ władca Szwecji i że jedynym celem jego działań będzie przywrócenie królowi Francji jego poprzedniej prerogatywy, jak również zaprowadzenie porządku w jego królestwie. Ponieważ jednak główną nadzieją wszystkich dobrych Francuzów był nadal Gustaw III, Breteuil ubolewał nad tym, że Hiszpania nie przekazała mu jeszcze obiecanych subsydiów. Na podstawie ostatnich depesz księcia de La Vauguyon baron wysnuł jednak wniosek, że Karol IV zdecyduje się przekazać królowi Szwecji przynajmniej 4 mln liwrów. La Vauguyon otrzymał też rozkazy, aby starał się pozyskać nowego ministra - hrabiego Pedro Pablo Arandę do koncepcji wypłacenia subsydiów Gustawowi III. Sam Breteuil, występując w imieniu Ludwika XVI, obiecał również Hiszpanom, że otrzymają oni zwrot wszystkich sum przekazanych władcy Szwecji na koszty projektowanej wyprawy do Francji. Baron odradzał jednak królowi pomysł ubiegania się o pożyczkę na konto Ludwika XVI. On sam posiadał co prawda odpowiednie pełnomocnictwa, ale uważał, że nie będzie w stanie odpowiednio ich wykorzystać. Twierdził bowiem, że ludzie posiadający pieniądze nie udzielą pożyczki bez pewnego zabezpieczenia, a domy handlowe, które dorobiły się na interesach $z$ królem Francji, sa niezdolne do podjęcia jakiegokolwiek ryzyka i nie udzielą mu pożyczki nawet na bardzo wysoki procent. Breteuil podzielał pogląd Gustawa III, że książęta, dysponując wielkimi środkami finansowymi, które otrzymali od mocarstw, mogliby się nimi podzielić $z$ królem Szwecji. Te środki, w połączeniu $z$ sub- 
sydiami hiszpańskimi, byłyby bowiem wystarczające do sfinansowania pierwszego etapu operacji wojsk szwedzkich. Co jednak w liście barona było najważniejsze to to, że po raz pierwszy opowiedział się on wyraźnie za otwartą interwencją w wewnętrzne sprawy Francji. Pisał bowiem, że większa część królestwa czeka tylko na sygnał, aby zrzucić jarzmo buntowników. Wyrażał także ogromna radość $z$ powodu przyjęcia przez Gustawa III planu operacji militarnych, który został przygotowany przez markiza de Bouillé. Zapewniał też władcę Szwecji, że francuska para królewska w pełni akceptuje wszystkie jego pomysły i $z$ niecierpliwościa oczekuje na wprowadzenie ich w życie. Swój list baron de Breteuil zakończył stwierdzeniem, że hrabia Fersen przekaże swojemu królowi wszystkie szczegóły dotyczące strasznego położenia Ludwika XVI i Marii Antoniny. Przy tej okazji pozwolił sobie również wyrazić nadzieję, że przyjaźń Gustawa III dla francuskiej pary królewskiej położy wreszcie kres wszystkim jej nieszczęściom ${ }^{108}$. Król Szwecji miałby więc wszelkie powody do zadowolenia, gdyby mógł zapoznać się z treścią tej przesyłki. List Breteuila dotarł jednak do Sztokholmu dopiero w dniu 6 kwietnia 1792 r. Równie wielką radość sprawiłby także Gustawowi III list od księcia Kondeusza. Także ta przesyłka dotarła jednak do stolicy Szwecji zdecydowanie zbyt późno ${ }^{109}$.

108 Por. L.A. de Breteuil do Gustawa III, Bruksela 25 III 1792, RA, Gallica vol. 524. Ten sam list por. M. Price, op. cit., s. 463-465. Por. też Z. Anusik, Dyplomacja..., s. 556-557; oraz id e m, France..., s. 514-515.

109 Dnia 28 III 1792 r. Louis Joseph książę de Condé odpowiedział na list Gustawa III z 20 I 1792 r. List króla Szwecji dotarł do adresata dopiero w dniu 27 III. Nie wynikało to jednak z zaniedbania barona Oxenstierny, ale $z$ faktu, że kurier wysłany ze Szwecji ciężko zachorował i został zmuszony do zatrzymania się przez dłuższy czas w Hamburgu. Condé przesyłał wyrazy wdzięczności dla króla za zainteresowanie okazywane dla spraw emigrantów i Francji. Twierdził, że Francja ma prawdziwych przyjaciół właśnie na Północy. To stamtąd przyjdzie ratunek dla dobrej sprawy i kara dla niszczycieli religii, królów i narodów. To z Północy przyjdzie dla Francji odrodzenie, przywrócenie jej należnej pozycji wśród państw Europy i uczynienie jej tym, czym powinna być dla zachowania równowagi politycznej, tak niezbędnej dla stabilizacji wszystkich tronów i egzystencji wszystkich imperiów. Książę dziękował też za ofertę schronienia się na Pomorzu, jaką otrzymał od Gustawa III dla siebie i swoich towarzyszy. Zapewniał o swojej chęci służenia ojczyźnie. Z niecierpliwością wyczekiwał spodziewanych posiłków od króla Szwecji i cesarzowej Rosji, które sa obecnie bardziej potrzebne niż kiedykolwiek. Widział jednak $z$ przykrościa, że w projektach mocarstw przyznano emigrantom bardzo poślednia rolę w przyszłych działaniach. Projektuje się bowiem oddalenie oddziałów księcia od wybrzeży morskich, gdzie zamierza wylądować Gustaw III ze 
Do ostatnich chwil życia Gustaw III interesował się rozwojem sytuacji na arenie międzynarodowej. Liczył na rychły wybuch wojny między Francją a Austrią. Nie doczekał jednak tej chwili. Sporządziwszy testament i uregulowawszy wewnętrzne sprawy swojego kraju, zmarł bowiem 29 marca 1792 r. ${ }^{110}$ Nils Åkeson zakończył swoją książkę stwierdzeniem, że umierający Gustaw III nie wiedział, że jego plany wobec Francji nie miały wielkich szans na realizację. W Wiedniu król od dawna spotykał się bowiem $z$ nieukrywaną niechęcią i lekceważeniem. Upadek Florida Blanki przekreślił wszelkie nadzieje na hiszpańskie subsydia. Katarzyna II nigdy nie miała też zamiaru uczestniczyć we francuskiej awanturze. Rozwój sytuacji na arenie międzynarodowej sprzyjał zresztą carowej. Śmierć Leopolda II, upadek Florida Blanki, kula Anckarströma to sekwencja wydarzeń, które sprawiły, że Katarzyna II mogła spokojnie zrealizować swoje plany wobec Polski, pewna, że nikt nie będzie w stanie jej w tym przeszkodzić ${ }^{111}$. W moim przekonaniu jest to jednak błędne rozumowanie. To nie czynniki zewnętrzne zdecydowały o załamaniu się planów Gustawa III i wycofaniu się Szwecji $z$ aktywnej polityki na arenie międzynarodowej. Rozstrzygająca w tej kwestii była bowiem wola regenta - księcia Karola Sudermańskiego, który od dawna należał do grona zdecydowanych przeciwników politycznych swego zmarłego brata ${ }^{112}$. Najbliżsi współpracownicy Gustawa III nie mieli też najmniejszych nawet złudzeń co do linii politycznej nowego rzadu. Najzagorzalszy zwolennik interwencji we Francji, baron Evert Taube, informując o śmierci króla Hansa Axela von Fersena, wiernego przyjaciela francuskiej pary królewskiej, napisał bowiem otwartym tekstem: „Moja rozpacz skończy się tylko wraz z końcem mojej egzystencji”. Szyfrem zaś dodał: „Nie licz więcej na to, mój drogi przyjacielu, że Szwecja udzieli jakiegokolwiek wsparcia nieszczęsnemu władcy Francji. Ukochany władca Szwecji nie żyje i nie ma już jedynego przyjaciela, który pozostał

swoim korpusem. Byłoby zaś dużo lepiej, gdyby zarówno on sam, jak i otaczająca go szlachta mogli służyć pod bezpośrednimi rozkazami króla Szwecji. W ten sposób mogliby bowiem zaznaczyć swoje przywiązanie do sprawy wszystkich władców. Zakończył zaś stwierdzeniem, że nie może się doczekać chwili, kiedy będzie mógł wraz z królem szwedzkim doprowadzić do przywrócenia tronu swojemu władcy. Por. L.J. ks. de Condé do Gustawa III, Bingen 28 III 1792, RA, Gallica vol. 522.

110 Por. A. Söderhjelm, Sverige..., s. 308; A. Geffroy, op. cit., t. II, s. 296;

Z. Anusik, Dyplomacja..., s. 558; ide m, France..., s. 515.

111 Por. N. Åke s o n, op. cit., Bd II, s. 221-222.

112 Por. zwłaszcza R.N. Bain, op. cit., vol. II, s. 213. 
Ich Wysokościom, nie ma już jedynego człowieka na świecie, który był zdolny do wprowadzenia w życie naszego wielkiego planu"113.

Zamykając nasze rozważania, zwróćmy uwage na znamienny fakt, że wybuchu wojny na Zachodzie Europy (21 kwietnia 1792 r. Zgromadzenie Prawodawcze wypowiedziało wojnę królowi Węgier i władcy Austrii Franciszkowi II) nie dożył człowiek, który od kilkunastu miesięcy konsekwentnie dążył do jej rozpętania. Trudno powiedzieć, czy wojska szwedzkie włączyłyby się do działań przeciwko rewolucyjnej Francji, zważywszy na to, że niemal w tym samym czasie armia rosyjska otrzymała rozkaz wkroczenia do Rzeczypospolitej. $Z$ drugiej jednak strony można również zapytać, czy w przypadku, gdyby nie dokonano zamachu na życie króla, rozkaz taki w ogóle zostałby wydany. Jedno natomiast wydaje sie pewne. Pod koniec życia Gustaw III wyraźnie zmienił swój pogląd na kwestię militarnej interwencji we Francji. Początkowo wydawało mu się, że wystarczy wysłanie kilkunastotysięcznego korpusu, aby przywrócić pełnię władzy Ludwikowi XVI. W początkach $1792 \mathrm{r}$. planował już jednak przeprowadzenie operacji na wielką skalę $z$ zaangażowaniem ogromnych sił i środków. Być może więc zaczął sobie zdawać sprawę $z$ faktu, że sytuacja wewnętrzna we Francji różni się w sposób zasadniczy od sytuacji w jego własnym kraju. Przez bardzo długi czas król nie dopuszczał bowiem do siebie myśli, że ogromna większość Francuzów nie życzy sobie powrotu do stosunków społecznych, gospodarczych i politycznych sprzed $1789 \mathrm{r}$.

Warto również zwrócić uwage na jeszcze jedną kwestię. Otóż Gustaw III był władca państwa, które brało aktywny udział w polityce europejskiej na poczatku, a następnie, po długiej przerwie, w końcu XVIII stulecia. Dość uzasadniony wydaje się w tej sytuacji pogląd, że aktywizację szwedzkiej polityki zagranicznej u schyłku rządów Gustawa III uznać należy za próbę odzyskania dla Szwecji, utraconej w „epoce wolności”, pozycji mocarstwowej. I chociaż próba ta zakończyła się niepowodzeniem, przykład szwedzki podważa dotychczasowe twierdzenia historiografii, jakoby w XVIII stuleciu państwa odgrywające mniejszą rolę na arenie międzynarodowej zmuszone były realizować cele polityczne wytyczane przez grono wielkich mocarstw. Można również zastanowić się nad tym, dlaczego inicjatywy dyplomatyczne Gustawa III spotykały się $z$ tak

113 Por. E. Taube do H.A. v. Fersena, Sztokholm 29 III 1792, cyt. według A. Sö derhjelm, Sverige..., s. 308-309. 
dużą rezerwą na większości dworów europejskich. Czy decydowało o tym wspomnienie słabości Szwecji z „czasów wolnościowych”, czy też raczej obawa przed restauracja potęgi szwedzkiej z poprzedniego stulecia? Sam Gustaw III bez wątpienia usiłował nawiązywać do tradycji Gustawa II Adolfa. Przez ogromną większość tak współczesnych, jak i potomnych uważany był jednak raczej za naśladowce Karola XII. Zainicjowane przez króla zabiegi dyplomacji szwedzkiej o utworzenie szerokiej koalicji mocarstw europejskich przeciwko rewolucyjnej Francji ujawniły inne jeszcze zjawisko. Okazało się bowiem, że u schyłku XVIII stulecia wszystkie bez wyjątku państwa kierowały się w swoich poczynaniach jedynie własnym, egoistycznym interesem. Przy obserwowanej w tym czasie wyraźnej globalizacji polityki europejskiej prowadziło to do sytuacji, w której uzyskanie konsensusu w jakiejkolwiek sprawie było po prostu niemożliwe...

\section{Bibliografia}

\section{ŹRódea ARCHIWALNE}

Riksarkivet w Sztokholmie (RA)

Diplomatica:

Gallica vol. 472, 476, 520, 521, 522, 524, 533, 555, 558.

Hispanica vol. 31, 33.

Muscovitica vol. 451, 489, 490.

Kungl. arkiv I. Handskriftsamlingen: Gustaf III.

Stafsundsarkivet:

Evert Taubes Samling. vol. I, vol. II.

Hans Axel von Fersens Samling. vol. 11.

\section{ŹRÓDEA DRUKOWANE}

Adlerbeth G.J., Historiska anteckningar. Efter en $i$ von Brinkmanska Arkivet på Trolle-Ljungby befintlig handskrift, utg. af G. Andersson, Del. I, Örebro 1856. Axel von Fersens dagbok, utg. av A. Söderhjelm, Bd I, Stockholm 1925. Coxe W., Travels into Poland, Russia and Denmark, vol. IV, London 1787. Fersen A. v., Rescue the Queen. A Diary of the French Revolution 1789-1793, eds

A. Carlsson, E. Elstob, London 1971.

Gustave III par ses lettres, ed. par G. v. Proschwitz, Göteborg-Paris 1986.

Hedvig Elisabeth Charlottas dagbok, utg. av C.C. Bonde, Bd II, Stockholm 1903. 
Kon. Gustaf III:s bref till Riks-Drotsen Grefve Axel Wachtmeister och Stats-Sekreteraren Ulric Gustaf Franc, efter handskrifter på Trolle-Ljungby, utg. af G. Andersson, Örebro 1860.

Konung Gustaf III:s bref till friherre G.M. Armfelt, utg. af E. Tegnér, [w:] Historiska Handlingar, Bd XII, Stockholm 1883.

Le comte de Fersen et la cour de France. Extraits des papiers du grand maréchal de Suède, comte Jean Axel de Fersen, publ. par R.M. Klinckowström, t. I, Paris 1877.

Michellessi D., Rewolucya szwedzka sprawa Gustawa III, dzisiejszego króla szwedzkiego $w$ roku 1772 utworzona, z przydatkiem formy nowego rzadu y pism zaciagajacych się do tey odmiany, przez... napisana, a z francuzkiego na oyczysty (j)ezyk przełożona, Warszawa 1778.

Nordin C.G., Dagboksanteckningar för åren 1786-1792, [w:] Historiska Handlingar, Bd VI, Stockholm 1868.

Ögonvitten om Gustav III, utg. av B. Hennings, Stockholm 1960.

Schinkel B. v., Minnen ur Sveriges nyare historia samlade af..., utg. af C.W. Bergman, Del. II (Gustaf III och hans tid 1788-1792), Stockholm 1852.

Schröderheim E., Skrifter till konung Gustaf III:s historia, utg. af E. Tegnér, uppl. 2, Stockholm 1892.

Sheridan C.F., A History of the Late Revolution in Sweden, London 1788.

\section{Opracowania}

Åkeson N., Gustaf III:s förhållande till franska revolutionen, Bd I-II, Lund 18851886.

Almquist J.A., Riksdagen i Gefle 1792, Upsala 1895.

Anners E., Humanitet och rationalism. Studier i upplysningstidens stafflagsreformer - särskild med hänsyn till Gustaf III:s reformlagstiftning, Lund 1965.

Anusik Z., Czy dwór berliński proponował Szwecji udział $w$ drugim rozbiorze Polski? Przyczynek do dziejów stosunków politycznych pomiędzy Sztokholmem, Berlinem $i$ Warszawa $w$ latach 1789-1792, [w:] Oświeceni wobec rozbiorów Polski, red. J. Grobis, Łódź 1998, s. 43-63.

Anusik Z., Dwór sztokholmski wobec wydarzeń $w$ Holandii $w$ latach 1785-1787, [w:] Gdańsk - Polska - Europa. Praca zbiorowa ofiarowana profesorowi doktorowi habilitowanemu Władysławowi Zajewskiemu $w$ siedemdziesiąta rocznice urodzin, red. Z. Kropidłowski, Gdańsk 2001, s. 87-101.

Anusik Z., Dyplomacja szwedzka wobec kryzysu monarchii we Francji $w$ latach 1787-1792, Łódź 2000.

Anusik Z., Edukacja oświeconego księcia. Wychowanie i wykształcenie szwedzkiego następcy tronu, królewicza Gustawa (późniejszego Gustawa III), [w:] Między barokiem a oświeceniem. Edukacja, wykształcenie, wiedza, red. S. Achremczyk, Olsztyn 2005, s. 260-279.

Anusik Z., France in Sweden's Foreign Policy in the Era of Gustav IIr's Reign 17711792, Łódź 2016. 
Anusik Z., Geneza i początki wojny szwedzko-rosyjskiej (kampania 1788 r.) $w$ świetle korespondencji Gustawa III, [w:] Między Zachodem a Wschodem, t. II (Studia ku czci profesora Jacka Staszewskiego), red. J. Dumanowski, B. Dybaś, K. Mikulski, J. Porazinski, S. Roszak, Toruń 2003, s. 43-62.

Anusik Z., Gustav III's coup d'etat of 19 August 1772. The end of the „Age of Liberty” in Sweden, "Sarmatia Europea. Polish Review of Early Modern History” 2011/2012, vol. II, s. 47-64.

Anusik Z., Kongres zbrojny u granic Francji. Niespetniona nadzieja kontrrewolucji spod znaku Tuileriów w latach 1791-1792, „Przegląd Nauk Historycznych” 2003, R. II, nr 2 (4), s. 111-179.

Anusik Z., Między Warszawa, Sztokholmem i Petersburgiem. Geneza rosyjskiej interwencji $w$ Polsce $w 1792$ roku $w$ świetle korespondencji ambasadora szwedzkiego $w$ Petersburgu - Curta von Stedingka, [w:] Przełomy $w$ historii. XVI Powszechny Zjazd Historyków Polskich (Wrocław 15-18 września 1999 roku). Pamiętnik, t. II, cz. 1, Torun 2000, s. 255-276.

Anusik Z., Misja polska w Sztokholmie w latach 1789-1795, Łódź 1993.

Anusik Z., Monarchistyczny zamach stanu Gustawa III z 19 sierpnia 1772 r. Geneza, przebieg, konsekwencje, „Przegląd Nauk Historycznych” 2013, R. XII, nr 1, s. $91-121$.

Anusik Z., O polska koronę. Dwór sztokholmski wobec kwestii sukcesji tronu $w$ Polsce $w$ dobie Sejmu Czteroletniego, [w:] Studia i materiały z dziejów nowo$\dot{z} y$ tnych, red. K. Matwijowski, S. Ochmann-Staniszewska, Prace historyczne XIII, Wrocław 1995, s. 147-167.

Anusik Z., O szwedzki alians. Karta z dziejów stosunków politycznych pomiędzy Sztokholmem a Warszawa $w$ dobie Sejmu Czteroletniego, „Acta Universitatis Lodziensis", Folia Historica 57, 1996, s. 77-106.

Anusik Z., Przykład szwedzki - konfederacja z Anjala, [w:] Król a prawo stanów do oporu, red. M. Markiewicz, E. Opaliński, R. Skowron, Kraków 2010, s. 163-180.

Anusik Z., Rokowania o polsko-szwedzki traktat sojuszniczy w 1790 roku, „Zapiski Historyczne” 1996, t. LXI, z. 2-3, s. 21-44.

Anusik Z., Szwedzki rywal Fryderyka Augusta. Gustaw III wobec projektów sukcesji tronu $w$ Polsce $w$ latach 1790-1792, „Rocznik Łódzki” 1997, t. XLIV, s. 89-115.

Anusik Z., Wydarzenia we Francji $w$ pierwszych miesiacach rewolucji (maj-październik 1789 r.) w świetle doniesien ambasadora Szwecji w Paryżu (Wersalu) Erika Magnusa Staëla von Holsteina, „Przegląd Nauk Historycznych” 2016, R. XV, nr 1, s. 85-127.

Awebro K., Gustaf III:s räfst med ämbetsmännen 1772-1779 - aktionerna mot landshövdingarna och Göta hovrätt, „Acta Universitatis Upsaliensis”, Studia Historica Upsaliensia 96, Uppsala 1977.

Bain R.N., Gustavus III and his Contemporaries 1746-1792. An Overlooked Chapter of Eighteenth Century History, vol. I-II, London 1894.

Barton H.A., Count Hans Axel von Fersen. Aristocrat in an Age of Revolution, Boston 1975. 
Barton H.A., Gustav III of Sweden and the Enlightenment, „Eighteenth Century Studies. An Interdisciplinary Journal", vol. VI, No. 1, Berkeley (University of California) 1972-1973, s. 1-34.

Barton H.A. Scandinavia in the Revolutionary Era 1760-1815, Minneapolis 1986.

Dembiński B., Rosya a Rawolucya Francuska, Kraków 1896.

Ericson L., Kriget till lands 1788-1790, [w:] Gustav III:s ryska krig, red. G. Artéus, Stockholm 1992, s. 69-109.

Essen Å.W., Johan Liljencrantz som handelspolitiker. Studier i Sveriges yttre handelspolitik 1773-1786, Lund 1928.

Findeisen J.P., „Królewski rewolucjonista”. Król Gustaw III u progu kapitalistycznej przebudowy szwedzkiego system feudalnego (1771-1792), „Zapiski Historyczne" 1997, t. LXII, z. 2-3, s. 69-85.

Forssell A., Histoire de l'administration des affaires étrangères 1721-1809, [w:] Histoire de l'Administration des Affaires Étrangères de Suède, Upsal 1940.

Geffroy A., Gustave III et la cour de France. Suivi d'une etude critique sur Marie-Antoinette et Louis XVI apocryphes, t. I-II, Paris 1867.

Glete J., Kriget till sjöss 1788-1790, [w:] Gustav III:s ryska krig, red. G. Artéus, Stockholm 1992, s. 110-174.

Godechot J., La contre-révolution française. Doctrine et action. 1789-1804, Paris 1961.

Hennings B., Gustav III. En biografi, Stockholm 1957.

Hennings B., Gustav III som kronprins, Uppsala 1935.

Hennings B., Ulrik Scheffer brev till Sophie Piper, „Historisk Tidskrift” [Stockholm] 1959, Bd LXXIX, s. 276-302.

Hjelt A.J., Sveriges ställning till utlandet närmast efter 1772 års statshwälfning, Helsingfors 1887.

Jägerskiöld O., Den svenska utrikespolitikens historia, Bd II, del. 2 (1721-1792), Stockholm 1957.

Landberg G., Den svenska riksdagen under den gustavianska tiden, [w:] Sveriges riksdag. Historisk och statsvetenskapling främställning, Bd VII, Stockholm 1932.

Lindberg H., En ränksmidare. Strödda blad ur 1700-talets partistrider, Stockholm 1928.

Lönnroth E., Gustavus III of Sweden: the Final Years. A Political Portrait, [w:] idem, Scandinavians. Selected Historical Essays, Göteborg 1977, s. 101-110.

Madariaga I. de, Russia in the Age of Catherine the Great, New Haven-London 1981.

Majewska G., Polityka handlowa Szwecji w latach 1720-1809, Wrocław 1991.

Malmström C.G., Sveriges politiska historia från konung Karl XII:s död till statshväfningen 1772, uppl. 2, Bd VI, Stockholm 1901.

Manderström L., Om Gustaf III:s yttre politik under de två senaste åren af dess regering, Stockholm 1859.

Mathiez A., La révolution française, t. I (La chute de la royauté), Paris 1928. 
Mathiez A., Rewolucja francuska, Warszawa 1956.

Nordmann C., Gustave III. Un démocrate couronné, Lille 1986.

Oakley S., Gustavus III:s Plan for War with Denmark, 1783-84, [w:] Studies in Diplomatic History, eds R. Hatton, M.S. Anderson, London 1970, s. 168-186.

Odhner C.T., Gustaf III och Katarina II åren 1783-1784, Stockholm 1879.

Odhner C.T., Gustaf III och Katarina II efter freden i Värälä, Stockholm 1895.

Odhner C.T., Sveriges politiska historia under konung Gustaf III:s regering, Bd I-III, Stockholm 1885-1905.

Rosander Y., Några brev från Gustav III och Charles de Vergennes till Fredrik Carl Sinclair under riksdagen 1771-1772, „Historisk Tidskrift”, Bd LXXIII, Stockholm 1953, s. 417-436.

Price M., Louis XVI and Gustavus III: Secret Diplomacy and Counter-Revolution 1791-1792, „The Historical Journal” 1999, vol. XLII, No. 2, s. 435-466.

Rystand G., Varör krig? Nagot om bakgrund och „orsaker” till Gustav III:s ryska krig, [w:] Gustav III:s ryska krig, red. G. Artéus, Stockholm 1992, s. 9-22.

Schück H., Gustav III:s statsvälvning 1772 I berättande källor och äldre litteratur, Historisk Arkiv 4, Uppsala 1955.

Söderhjelm A., Fersen et Marie-Antoinette. Journal intime et correspondance du comte Axel de Fersen, Paris 1930.

Söderhjelm A., Revolutionärer och emigranter, Stockholm 1918.

Söderhjelm A., Sverige och den franska revolutionen. Bidrag till kännedom om Sveriges och Frankrikes inbördes förhållande $i$ slutet av 1700-talet, Bd I (Gustav III:s tid), Stockholm 1920.

Stålhane H., Gustaf III:s resa till Italien och Frankrike, Stockholm 1953.

Stavenow L., Anckarström Jacob Johan, [w:] Svenskt Biografiskt Lexikon, Bd I, Stockholm 1918, s. 610-614.

Tham W., Konung Gustaf III och rikets stander vid 1789 års riksdag, Stockholm 1866.

Waern C.F., 1786 års riksdag, [b.m.] 1868.

\section{Gustav III's attitude towards French Revolution}

\footnotetext{
Gustav III was a King of Sweden from 1771 till 1792. From the very beginning $J$ of his reign he was firmly associated with France. Thanks to its support, he made a monarchist coup d'état in August 1772. For the next fifteen years he was the closest ally of the court of Versailles. The internal crisis, which started in 1787 , meant that France was no longer able to play the current role in the international arena. One of the first European politicians who became aware of that fact was Gustav III. In the years 1788-1790, against the position of France, he led war with Russia, which he ended in August 1790. There is no doubt that he did it
} 
because of the developments in France. The king had long been terribly afraid of any revolutions. And it was not about social or economic changes caused by revolution. It was so as the King of Sweden considered a revolution a destructive force threatening all the thrones. He was afraid that the example of France, where the position of the king weakened with each passing month, could lead to a collapse of the monarchy in all other European countries. For this reason, Gustav III came up with the idea of making the armed intervention in France.

In 1791 the most important thing for him was rescuing the threatened French monarchy. Not finding understanding with the representatives of the Triple Alliance (England, Prussia, Holland), he increasingly began to lean towards the concept of an alliance with Russia. A decision to sign the treaty of alliance with Catherine II finally sealed failure of Louis XVI's escape from Paris in June 1791. Almost immediately after stopping the King of France at Varennes, Gustav III started to put together a broad coalition of powers whose primary aim was to rescue the institutions of the French monarchy. His initiatives in this regard, however, were not understood at European courts. Swedish diplomats met almost everywhere with cool and sometimes even hostile reception. The only result of a large-scale diplomatic action was the signing of the Drottningholm treaty with Russia in October 1791. It is also worth noting that Gustav III remained in constant contact with Louis XVI and his trusted representative in exile, Louis Auguste, Baron of Breteuil. Gustav III was murdered at a time when his proposals were accepted by Louis XVI and Marie Antoinette. The Tuileries court, initially quite sceptical towards the idea of an armed intervention in France. In March 1792 however the Baron of Breteuil, acting on behalf of the French royal couple, agreed on both, landing of the Swedish corps in Normandy and the organisation of a new escape of the royal family from Paris. The death of Gustav III shattered, however, all those intentions. The dying king also never learnt that in late March 1792 a chance for fulfilling all his desires and dreams appeared.

Keywords: Gustav III, French Revolution 1789-1792, Sweden in the second half of $18^{\text {th }}$ century, Sweden's foreign policy in the second half of $18^{\text {th }}$ century, political situation in Europe in the second half of $18^{\text {th }}$ century. 